\title{
WORKING ON THE POTTER'S WHEEL: TECHNOLOGICAL INSIGHTS INTO MYCENAEAN POTTERY PRODUCTION
}

Maria Choleva, ${ }^{1}$ Reinhard Jung ${ }^{2}$ and Eleftheria Kardamaki ${ }^{3}$

Abstract: The present paper deals with the wheelbased manufacturing technology employed for the production of pottery in central Laconia and the Argolid during the Mycenaean palatial period (roughly 1450-1200 BCE). The main set of data comes from the combined macroscopic and X-Ray analyses on pottery discovered at the palace of Ayios Vasileios in Laconia. Additional material of Argive/NE Peloponnesian provenance was examined as well for comparative reasons. The latter comes from Tiryns and Tall Zirā'a, Jordan. Although growing evidence suggests that wheelforming techniques can be more variable than one would have traditionally thought, very few studies have examined the use of the potter's wheel during the Mycenaean period and the underlying craft behaviours. Our study suggests that the knowledge of this tool in the Argolid and central Laconia was not associated with the wheel-throwing technique but the so-called wheel-coiling, and was based on similar levels of expertise. However, we can also observe variations between these two regions, especially in the ways of mastering the rotary device within the forming process. The manufacture of the wheelmade pottery in Mycenaean Greece implies thus a complex technological phenomenon that involved different potting communities participating in the social and economic organization of palatial pottery production.

\footnotetext{
1 INSTAP postdoctoral fellow, Fitch Laboratory, British School at Athens, 52 Souedias Street, 10676 Athens, Greece,m.choleva@bsa.ac.uk.

2 Institute for Oriental and European Archaeology, Austrian Academy of Sciences, Hollandstr. 11-13, 1020 Vienna, Austria; Reinhard.Jung@oeaw.ac.at.

3 Institute for Oriental and European Archaeology, Austrian Academy of Sciences, Hollandstr. 11-13, 1020 Vienna, Austria; Eleftheria.Kardamaki@oeaw.ac.at.

4 Mountjoy 1993, 33.

5 Furumark 1941, 12-15. Arne Furumark has already noted that "the coarse ware ... is sometimes hand-made" (ibidem, 12) and that miniature vessels in all periods are also hand-made. For the phases LH II-IIIA1 he stated "big vases have sometimes been built up in sections or remodeled by hand after the turning” (ibidem, 14).
}

Key words: Ayios Vasileios, Laconia, Argolid, Mycenaean pottery, wheel-coiling, wheel-throwing, pottery communities

\section{Introduction}

\subsection{The technological and economic importance of the potter's wheel in Mycenaean ceramic production}

The present paper deals with the technological and economic importance of the potter's wheel in Mycenaean ceramic production mainly during the palatial period from LH IIB/IIIA1 to LH IIIB Final (roughly 1450-1200 BCE).

It is common knowledge that Mycenaean pottery was produced on the potter's wheel..$^{4}$ This seems to hold good not only for the well-known painted pots, but also for the unpainted fine to medium-coarse classes, ${ }^{5}$ which are dominant in any regular settlement context in Greece, from the Peloponnese in the south up to Thessaly in the north. ${ }^{6}$ However, even today, many decades after the fundamental monographs that classified Mycenaean pottery as a whole and set the standards for all the work to come, technological studies focusing on the production methods of Mycenaean pottery can almost be counted on one hand. ${ }^{7}$ Growing evidence from neighboring regions such as the

\footnotetext{
For some statistics of painted versus unpainted Mycenaean vessels see Podzuweit 2007, Beil. 38; see Thomas 2005, 459, Tab. 2, for the percentages of painted and plain wares in selected LH IIIB deposits from the Peloponnese.

LEONARD et al. 1993 (for a number of small stirrup jars found in Greece, Cyprus, Egypt and the Near East); LevI and Cannavò 2014, 365-368, 373-375 (for Mycenaean and Mycenaeanizing pottery produced in southern Italy); Lis 2016 (on unpainted pots from the palace of Pylos, using a macroscopic approach); MARABEA 2019 (exclusively on Aeginetan unpainted coarse wares from Kanakia in Salamis, using a macroscopic approach, cf. also MARABEA 2012, 177, commenting on Mycenaean pottery). - Thus, we can still agree with Furumark that "no exact and fully adequate terminology can be created until we have a purely technical examination of the material, based on mineralogical and chemical analyses and on reconstructions of the methods of manufacture.” (FurUMARK 1941, 11)
} 
Cyclades and Crete suggests that pottery production using the wheel can have been much more variable than one would have traditionally thought. Apart from cultural practices, this technological variability can be expected to have been closely dependent on the economic and social structures in different Bronze Age societies. This clearly demonstrates the need for a new technological approach towards Mycenaean pottery with a clear diachronic perspective.

The success story of Mycenaean pottery started during LH I, when Peloponnesian (most probably Argive $^{8}$ ) potters combined Cretan elements of Minoan Neopalatial origin and traditional Middle Helladic traits to create an innovative, wheelmade ceramic class (part of which was decorated with iron-based lustrous-fired paint) ${ }^{9}$ that soon found consumers not only on the Greek mainland. Already by LH I painted Mycenaean pottery was exported across the Aegean and Ionian seas to reach neighboring as well as remote regions such as the Cycladic islands in the east, ${ }^{10}$ the Chalcidice in the north, ${ }^{11}$ the Aeolian Islands and the Gulf of Naples in the northwest. ${ }^{12}$ However, even in the very centers of its invention, Mycenaean pottery first remained just one pottery class among others (locally made and imported), as closed funerary contexts from Mycenae, Lerna and Asine or settlement contexts e.g. from Tsoungiza demonstrate..$^{13}$

At this point one should recall that Mycenaean ceramics were of course not the first ceramic products made on the wheel in continental Greece. The earliest wheelmade pots left the workshops already during the Early Bronze Age. Interestingly, however, recent research has demonstrated that the introduction of the potter's wheel as a means of labor in an advanced stage of EH II neither led to an abrupt end nor to a steadily increasing abandonment of the traditional hand-forming technologies. During the late stages of the Early Bronze

\footnotetext{
See below n. 46.

9 Dietz 1991, 31; Mountuoy 1993, 31-38; Dickinson 2014; RUTTER 2015.

10 Marthari 1993, 249-250, Pl. 31a-d; Mountjoy 2007, 325326.

$11 \quad$ Found especially at Toroni: Morris 2009-2010, 53-57.

12 Jung 2006, 59-70, 76-81, 88-94; Jones and Levi 2014, 200-204, 239-240.

13 Dietz 1991, 209-211, 243-250; Lindblom and Manning 2011, 144-145, Fig. 4; RutTer 2015, 213-220, Tab. 2.

14 Choleva 2015; Choleva 2018A; Choleva 2020A; Choleva 2020B; Choleva in press; see also Spencer 2010.
}

Age and throughout all of the Middle Bronze Age only small groups of potters dedicated themselves to the difficult and time-consuming process of learning the art of forming pottery on the wheel, so that only a minor portion of ceramic vessels during each chronological phase was in fact wheelmade. ${ }^{14}$ Only in the Late Bronze Age the technologies employing the potter's wheel became the dominant ones among the potters workshops on the Greek mainland. ${ }^{15}$ At the end of this process, we witness a widespread use and production of Mycenaean pottery exceeding by far the geographical borders of the southernmost part of the Balkan peninsula and the islands in the Aegean Sea.

\subsection{Questions addressed and study material}

The newly found palatial center of Ayios Vasileios in Laconia serves as the main case study of the present paper, because this site offers a long sequence of well-dated pottery deposits, in which the earlier phases of the palatial area are exceptionally well represented ${ }^{16}$ - phases that in other palaces cannot be studied in such detail. Given the special role the Argolid seems to have played in the development of Mycenaean pottery production, we also chose to investigate the products of Mycenae and Tiryns - representing the northern and the southern Argolid respectively. ${ }^{17}$ Here, we use these Argive data mainly for comparative reasons. A detailed technological study of Argive Mycenaean pottery would of course merit a project in its own respect.

\subsubsection{Technological issues}

The established facts provoke many questions that inspired our study. A first series of these tackles technological issues. At the outset, it is necessary

\footnotetext{
15 For the workshop excavations see HanSEn Streily 2000. More recent finds include clay preparation basins at Corinth (35тн EpHorate 2016, 429-432, Figs. 12 and 18).

16 KARDAMAKI 2017.

17 The Argive products we present were found at Tiryns and Tall Zirā'a in Jordan. The results of NAA as well as macroscopic fabric classification show that most of the Mycenaean vessels exported to Tall Zirā'a were produced at Mycenae. Several of the vessels found at Tiryns also seem to belong to fabrics produced at Mycenae, while others ought to be local (southern Argive) based on the macroscopic fabric examination.
} 
to determine, since when the Mycenaean potters regularly installed the potter's wheel as their main means of labor. In view of the variety of techniques, with which the wheel had been used after its first appearance during the Early Bronze Age (see below), one should examine if this technological plurality continued - both in space and in time - throughout Late Bronze Age. We might then ask if it is possible to observe a growing standardization of craft behaviours in Mycenaean pottery production. A final question links the technological issues directly to economic and social ones: are technological changes related in a qualitative and/ or quantitative way to the emergence of Mycenaean pottery's mass production ${ }^{18}$ ?

\subsubsection{Related economic and historical issues}

If there is a link between developments in manufacturing techniques and Mycenaean mass production, when did these progressive changes occur or when did their dynamics accelerate? Were they bound to certain general changes in Mycenaean economy and culture that characterize the history of Mycenaean society? Is there a dialectical relationship between the pottery technology and the development of production, i.e. could the former fully unfold because of the latter making a qualitative leap? We will also ask more specifically, if the generalized use of Mycenaean pottery in many Aegean regions (starting at least in late LH IIB or LH IIIA $1^{19}$ ) was related to technological changes and/or a growing standardization of pottery production. In addition, one has to take into consideration a second realm of inquiry, i.e. the one outside the Aegean itself, asking if the growth of exportrelated production - with a first enhancement in LH IIIA1 and an exponential boost in LH IIIA2 depended on technological changes and standardization in certain Aegean regions, which have been identified as exporters by chemical analyses.

18 We may confidently use this term for referring to the tens of thousands of unpainted Mycenaean vessels stored in a Mycenaean palace (cf. Hruby 2014, 49-50), to the thousands of pots found in the destruction deposits of houses belonging to palatial functionaries (e.g. the LH IIIA2 Late Petsas House, Shelton 2015) as well as to the export of large quantities of painted fine-ware originating from a single production region in the northern Argolid to consumers all over the eastern Mediterranean and Egypt (see below n. 20).
These two phenomena of an ever-widening distribution of Mycenaean pottery are linked in special ways to the region of the Argolid. Since LH IIIA2, we are dealing with direct exportation of Argive products mainly to the eastern Mediterranean, products that were even specially designed so as to satisfy the needs of the eastern consumers and to appeal to their aesthetic predilections. ${ }^{20}$ Finally, by comparing different regions of Greece in a diachronic perspective, we can try to answer the question, if the degree of production standardization in those palatial regions point to common teaching traditions that were organized according to a unified/single model.

We have studied a wide spectrum of pottery categories from both Ayios Vasileios and Tiryns, and we supplement this by a group of mainly Argive pots found at Tall Zirā'a in Jordan. In this paper we limit our presentation to pots, which are made with wheel-based techniques and can be identified as products of the region, in which they were found (with the exception of Tall Zirāa a, of course). Thus, we discuss in our paper neither handmade storage vessels found at Ayios Vasileios nor Cretan, Kytheran and Aeginetan imports present in both Laconia and the Argolid.

By using the method of X-Radiography for the pottery of Ayios Vasileios and Tall Zirā'a in combination with a detailed macroscopic examination and typological analysis of the material from all three sites, our study presents the first data of their kind for the Late Bronze Age in continental Greece. A chaîne opératoire approach seems to be especially well-adapted for our endeavour. It contextualizes multiple data sets from typological, analytical and experimental studies placing emphasis on the technical aspects of objects. ${ }^{21}$ In the past few decades, the integration of ethnoarchaeological studies has advanced our understanding of the various processes that are not always reflected in the archaeological material, such as

19 Mountjoy 1999, 446, 743-744, 823-824, 982-983; Mountjoy 2007, 241-243; Eder and Jung 2015, 127-128; Koulidou ET AL. 2017. On the North Aegean islands, a large part of the assemblages belongs to local or Minoanizing wares, but locally produced Mycenaean decorated and plain wares are also common (Boulotis, KARDAMAKI and BoLоті 2017, 49 and Tab. 1).

20 Ånerström 1987, 119-120; Podzuweit 2007, 302; Jung 2015; Mountuoy 2015.

21 Roux 2011b. 
the craft behaviours behind production, interaction of craft specialists, the response of consumers and the mechanisms behind the organization of pottery production. One of the most intriguing aspects of these studies is, amongst others, the possibility to assess, question or further confirm well-established theories and models of production in a way that was not possible before. We will address the questions outlined above, but we are fully aware of the fact that at present it may not be possible to answer all of them with the same degree of certainty, just because the technological examination of Mycenaean pottery is still a young and developing yet very promising field of research.

\section{History of research: wheel-throwing or wheel-fashioning}

\subsection{The wheel-based techniques and the history of research}

\section{Definition of terms}

According to recent studies, the wheelmade pottery can be either (1) thrown from a lump of clay or (2) formed in combining a hand-forming technique such as coil-building with the kinetic energy of the potter's wheel. ${ }^{22}$ The products of the first technique are called henceforth "wheelthrown", those of the second technique "wheelfashioned" or "wheel-coiled", whereas "wheelmade" refers to each pot bearing traces of what Valentine Roux has named Rotational Kinetic energy (RKE) independently of the specific technique used. ${ }^{23}$

Four methods of exploiting RKE in combination with coil-building can be recognized: 1, 2, 3, and 4 (see below) (Tab. 1). Moreover, two principal types of potter's wheels can be distinguished: (1) a tournette (or slow rotary device), which consists of a single wheel rotated around an axis (either by the potter him/herself or by an assistant) and can typically reach speeds of about 80 to 100 rotations per minute (rpm), and (2) a kick wheel (or fast rotary device) moved by the potter's own foot which can reach a minimum speed of $150 \mathrm{rpm}^{24}$

There is no iconographic evidence for the existence of the kick wheel during the Bronze Age in the eastern Mediterranean, the Near East or Egypt, ${ }^{25}$ while even the earliest depictions of wheels in Greece that date to the Archaic period do not provide clear indications of the type of device used. ${ }^{26}$ In view of the missing iconographic evidence, reconstructions of kick wheels based on two Minoan excavation assemblages of Neopalatial (LM IB) and Mycenaean palatial (LM IIIB) date ${ }^{27}$ cannot yet be taken as definite proofs for the existence of this type of device in the Late Bronze Age Aegean.

\begin{tabular}{|c|c|c|c|c|c|}
\hline & \multicolumn{3}{|c|}{ Roughout stage } & \multirow{2}{*}{$\begin{array}{c}\begin{array}{c}\text { Preform } \\
\text { stage }\end{array} \\
\begin{array}{c}\text { Shaping the } \\
\text { roughout }\end{array}\end{array}$} & \multirow[b]{2}{*}{$\begin{array}{c}\text { Degrees of specialisation in } \\
\text { RKE gestures }\end{array}$} \\
\hline & $\begin{array}{l}\text { Forming } \\
\text { the coils }\end{array}$ & $\begin{array}{l}\text { Joining the } \\
\text { coils }\end{array}$ & $\begin{array}{l}\text { Thinning } \\
\text { the walls }\end{array}$ & & \\
\hline Method 1 & $\begin{array}{l}\text { Without } \\
\text { RKE }\end{array}$ & $\begin{array}{l}\text { Without } \\
\text { RKE }\end{array}$ & $\begin{array}{l}\text { Without } \\
\text { RKE }\end{array}$ & With RKE & Low \\
\hline Method 2 & $\begin{array}{l}\text { Without } \\
\text { RKE }\end{array}$ & $\begin{array}{l}\text { Without } \\
\text { RKE }\end{array}$ & With RKE & With RKE & Moderate \\
\hline Method 3 & $\begin{array}{l}\text { Without } \\
\text { RKE }\end{array}$ & With RKE & With RKE & With RKE & High \\
\hline Method 4 & With RKE & With RKE & With RKE & With RKE & Very high \\
\hline
\end{tabular}

Table 1 The four wheel-coiling methods and their degrees of technical specialisation in RKE-mediated gestures (based on Roux \& COURTY 1998).

22 CourTy and Roux 1995; Roux 2017, 101-121.

23 Roux 1994.

24 Roux and Miroschedji 2009, 164-165; Berg 2015, 17, 19, Fig. 3. For wheel-typologies and relevant discussions, see also Rice 1987, 133-136; Pierret 1995, 27-29; JefFra 2011, 44-48; Doherty 2012, 15-63; Berg 2013, 116-117. For experiments on speeds, see also Amiran and Shenhav 1984; Powell 1995, 334.

25 Berg 2015, 17-19, Figs. 1-3.

26 HASAKI 2019, 295-297.

27 Chatzi-Vallianou 1995, 1036-1046; Chatzi-Vallianou 2017, 144-145, Fig. 5.64. 


\section{The wheel-based techniques}

The appearance and spread of wheelmade pottery during prehistory is traditionally associated with the so-called 'fast' wheels and the wheel-throwing technique, and is usually interpreted as evidence for standardization and intensification in pottery production. ${ }^{28}$ The pioneering work of Valentine Roux on the phenomenon of the potter's wheel in the Levant, however, has questioned this simplistic view by shedding light on more complex processes of technological innovation. ${ }^{29}$ Her extensive study of the manufacturing techniques of Levantine wheelmade production during a period spanning from the late $5^{\text {th }}$ millennium to the $2^{\text {nd }}$ millennium BCE has demonstrated that the wheelmade pottery is not produced by clay lumps but instead by coils fashioned on 'tournettes'. ${ }^{30}$

The identification of the wheel-fashioning, and especially the wheel-coiling technique has altered our view of the history of the potter's wheel and has shed light on two main 'thresholds' in the history of wheelmade pottery. ${ }^{31}$ The first threshold is associated with the emergence of RKE, which is integrated into traditional manual potting practices and signals the appearance of the new 'hybridized' technique of wheel-coiling. In this case, the rotary device is able to produce RKE sufficient to resist friction and to enable uninterrupted and continuous manual movements involved in a forming operation on the wheel. ${ }^{32}$ The use of RKE entails innovative motor and cognitive skills that are specific and complex, time-consuming to learn and difficult to acquire, not least because they are radically different from those involved in hand-forming techniques. ${ }^{33}$ After a detailed technological study of ancient ceramics and experimental studies, Roux and Courty have identified four possible ways of exploiting RKE in combination with coiling. ${ }^{34}$ Following the main forming operations of coiling

\footnotetext{
Cf. BALDi and Roux 2016, 1-2.

Roux 2003; Roux 2010.

30 Roux 2008; Roux 2009; Roux and Miroschedu 2009; BALDI and Roux 2016.

31 Roux 2010, 221-222, Fig. 13.1-2.

32 Courty and Roux 1995, 22; Gelbert 1997, 17-19; see also Pierret 1995, 26-34.

33 Roux and Corbetta 1990, 69, 75-78; Roux and Brill 2002; Roux 2007, 159-161. For learning processes, see BRILL 2002.
}

(placing and joining the coils, thinning and shaping the roughout), the four wheel-coiling methods were established according to the stage during which the wheel is inserted into the operational sequence involved in the making of the roughout of the pot. Earlier use of RKE means gradual abandonment of gestures associated with the hand-forming and increasing adoption of gestures mediatized by RKE. ${ }^{35}$ Each wheel-coiling method (1 to 4$)$ thus implies distinct specialized gestural movements corresponding to an escalating mastery and familiarity with RKE (see Tab. 1). The second threshold of the wheel's history is defined by the appearance of the wheel-throwing technique and hence the rotation of clay lumps. Wheel-throwing comprises the previous RKE knowledge, but introduces further innovative specialized gestures involved in new forming operations, i.e. centering and hollowing clay lumps on the wheel. ${ }^{36}$ New modalities now determine the design and usage of rotary devices, such as their capacity to produce RKE resistant to the frictions caused by the strong pressures exerted on the lump during centering operations. ${ }^{37}$ Throwing clay lumps means a total abandonment of the gestures related to hand-building and marks a qualitative shift toward a new set of cognitive and motor skills entailing a total alteration of gestures under the impact of RKE. ${ }^{38}$

The cognitive and motor skills enacting forming techniques are considered as the most stable aspect of craft behaviours because they are learned and internalized only through systematic exercise and practice during apprenticeship and are transformed into rooted habits. ${ }^{39}$ From this perspective, the forming techniques are seen as specific to groups of potters sharing the same craft behaviours, derived from common contexts of apprenticeship. As such, these techniques may represent indicators of distinct production entities behind particular ceramic assemblages. ${ }^{40}$ In light

\footnotetext{
34 Roux and COuRTy 1998; Roux 2017, 114-119. For further experiments in wheel-coiling see JeFFrA 2011; JEFFra 2013; RÜCKL and JACOBS 2016.

35 Roux and Courty 1998, 748, 752-753, Fig. 1, Tab. 1.

36 Rye 1981, 74; Roux 2017, 101-113.

37 Roux and Corbetta 1990, 29-43; Pierret 1995, 23-25.

38 Roux and Corbetta 1990, 28-41; Gelbert 1997, 17-20.

39 Gosselain 2000, 192-193; Minar and Crown 2001, 373; Brill 2002; Roux 2011A, 177-179.

40 Gosselain 2011, 216-217; Roux 2007, 164-165; Roux 2011A, 180-181; Roux 2011B, 81-82; see also Choleva 2018A, 55-65 with references.
} 
of this, each way of using the wheel is the result of specific learning processes and hence a marker of production units mastering the wheel according to a certain degree of technical specialization. Consequently, the identification of wheel-forming techniques and methods within an assemblage enables shedding light on aspects of craft behaviours characterizing the organization of apprenticeship and the transmission of technical knowledge within a context of production. ${ }^{41}$

Exploring the social and economic dynamics underlying various forming techniques, archaeological researchers have begun to investigate specific manufacturing technologies involved in the production of wheelmade pottery during the Bronze Age in the Aegean. ${ }^{42}$ However, the question of the forming techniques of the wheelmade Mycenaean pottery has still not yet been fully addressed.

\subsection{Earlier work and current studies on wheel technology during the Mycenaean period}

Since the very beginning of the Mycenaean studies, scholars were (and are still) making a considerable effort to detect the influences going into the production of Mycenaean pottery, to define its initial stages and even the first manufacturing region of that new class. ${ }^{43}$ Since then, the material has been classified with an exquisite typology $y^{44}$ (often with a special focus on the decorated vessels) and several series of provenance analyses have been conducted by various laboratories. ${ }^{45}$ This led to very important conclusions regarding the presence and distribution of various workshops. While the first and earliest production center of the lustrous

$41 \quad$ Roux 2009; Roux and COURTY 2005.

42 For an overview, see Knappett and Van der Leeuw 2014; KNAPPETT 2016.

43 Furtwaengler and Loeschcke 1886; Blegen 1921, 36-74; Fimmen 1921, 89-100, 140-167.

44 Furumark 1941; Mountjoy 1986; Podzuweit 2007.

45 Mommsen et Al. 1988; Mommsen et Al. 2002; Badre et Al. 2005; Tomlinson et Al. 2010; Mountjoy and Mommsen 2015; see also Demakopoulou et al. 2017. See Jones and Tomlinson 2009, Appendix G-CD, 150 and Fig. G.1 for a map showing the various methods of chemical analyses conducted on Mycenaean pottery mainly in the region of Peloponnese.

46 Marketou et al. 2006; French et al. 2008, 121-122, Tab. A3.4; Dickinson 2014; RutTer 2015, 221-222. LindBLOM ET AL. 2015, 233-234 suggest the Argolid as the region where painted, i.e. Mycenaean pottery of LH I (e.g. the Vapheio cups, but also several small closed shapes), is still not entirely resolved, the region of the Argolid seems to be the most likely candidate. ${ }^{46}$ Despite this, little attention was given to forming techniques, but according to a general and widely accepted consensus the Mycenaean pottery was for its most part wheelmade. ${ }^{47}$ The term was often used without further explanation, but occasionally with explicit reference to the wheelthrowing technique. ${ }^{48}$ One important reason for this lack of interest in manufacturing technology of the Mycenaean pottery is the focus on the study of the decorated pottery, shared by many experts. Due to its more 'humble' appearance and restricted significance for issues concerning relative chronology, the largest part of Mycenaean ceramic assemblages (at least in settlements), namely the one consisting of fine, medium-coarse and coarse plain wares, was at the same time until recently the most neglected one. ${ }^{49}$ It was only after scholars started to pay more attention to these wares that technological studies became more frequent and their important role was realized.

A new impulse to the field of Mycenaean pottery came from Crete and the Cyclades where such technological studies have started in the early 2000s. Based on the macroscopic examination of wheelmade pottery, Carl Knappett produced a rich corpus of technological data from Middle Minoan Knossos and integrated into the archaeological discussion very early the results of experimental and ethno-archaeological works from all around the world. ${ }^{50}$ Another important turn took place with the work of Ina Berg who was the first to conduct $\mathrm{X}$-Radiography analysis on a large number of ves-

the Mycenaean style was created in LH I, but they also stress the fact that the LM IA pottery from Kythera and the LH I Mycenaean pottery from the Argolid are indistinguishable from each other. Both ceramic groups are considered to be locally produced on Kythera and in the Argolid respectively.

47 For a discussion on the problem of a general lack of detailed descriptions on manufacturing techniques among Mycenaean pottery studies see Berg 2013, 114, Tab. 1.

48 Hruby 2006. For similar assumptions regarding Minoan pottery see DAvis and Lewis 1985, 83 (wheelthrown as a way to produce pottery faster).

49 To this, one should add the early excavation practices of discarding plain wares.

50 KNAPPETT 2004. 
sels from Knossos that covered a wide range of dates and fabrics (MM IB - LM IA). ${ }^{51}$ Most important, with the works of Knappett and Berg, a new discussion in Minoan archaeology was initiated that referred to the identification of the different RKE techniques. ${ }^{52}$ They were able to show that several hand-building and wheel-forming techniques existed in Minoan Crete. More specifically, a very large percentage of the vessels were wheelcoiled since MM IB when the wheel was first introduced in Crete. ${ }^{53}$ However, one aspect that is of particular significance for understanding the Minoan technology seems to be thus far unresolved. This relates with the co-presence or not of wheelthrown pottery along with the wheel-coiled one.

The debate on the question of the wheel-based techniques has two facets:

(a) On the one hand, the macroscopic similarity between wheelthrown and wheel-coiled vessels renders the distinction between RKE techniques very difficult, which often led to diverging interpretations of surface features. ${ }^{54}$ Berg and Caroline Jeffra were the first to explore systematically this issue in Minoan pottery by using different type of analyses..$^{55}$ Jeffra conducted an extended macroscopic and experimental analysis on MM IB - LM IA wheelmade pottery from different Cretan sites by applying the four-type classification system of

51 Berg 2009, 141-142. To be sure, X-radiography had been introduced earlier to Aegean Bronze Age pottery studies (LeONARD et al. 1993).

52 Knappett 1999, 119; Berg 2008; Berg 2009; Berg 2013; Calor 2011; Jefrra 2011; 2013; Todaro 2019. For comparable studies in MBA Cyclades and Kythera see BroodBanK and Kiriatzi 2007; Gorogianni et al. 2016A; Gorogianni et Al. 2016B; Abell and Hilditch 2016.

53 Knappett 2004; 2016; Berg 2008; 2009; 2013; cf. Caloi 2011. For a synthetic work on Minoan wheel phenomenon see Knappett and VAn der Leeuw 2014.

54 Roux 1994; Courty and Roux 1995.

55 Berg 2008; Berg 2009; JefFra 2011; JefFra 2013.

56 JefFra 2011, 152-158; JefFra 2013, 37-43 and tab. 3 and figs. 7-13. JEFFra has identified methods 1 to 3 on Crete. Berg 2009, 168, Fig. 2, on the other hand did not distinguish between the various wheel-based methods but subsumed all under the term "wheel-coiled".

57 KNAPPEtT 2004, 260-264. For the introduction of the potter's wheel in Egypt, see especially ArNOLD and Bourriau 1993, 43-44. For a recent unpublished dissertation on the wheel phenomenon in Egypt see DoHerty 2012.
Roux. She concluded to reject the hypothesis regarding the existence of Minoan wheelthrown pottery and argued instead that the majority of the material was in reality wheelcoiled. ${ }^{56}$ This brings about an important implication as it forces us to reconsider our wellestablished concepts of the technological innovation as a whole. Knappett, in turn, who sees the potter's wheel being transferred from Egypt to Crete, ${ }^{57}$ has recently revised his original assumption that wheelthrown pottery evolved out of the hand-building techniques, whereas the hybrid methods followed later, when the Minoan potters tried to produce larger vessels on the wheel. ${ }^{58}$ He has detected the macrotraces of the coiling technique on a small part of material and on vases that were traditionally considered to be wheelthrown (e.g. conical cups). ${ }^{59}$ By contrast, Berg argued for the existence of the wheel-throwing technique on the base of X-Radiography, which according to her offers a secure way to achieve the distinction between wheel-throwing and wheel-coiling. ${ }^{60}$ Berg suggests the existence of several examples of wheelthrown pottery in Knossos dating from MM IB to LM IA that appear next to other vessels made by wheel-coiling techniques. ${ }^{61}$ Regarding similar studies on wheel-based techniques during the EBA and the MBA in

58 Knappett 1999, 128; Knappett 2004, 259. For recent discussions see KnAPPETT and VAn DER LeEUW 2014; KNAPPETT 2016.

59 KnAPPETt 2004, 260-261, Fig. 20.1. Small pots from MM II in general could have been thrown from the hump, as well as the so-called egg-shell wares (KNAPPETT 1999, 122123). MacGillivray 1998 suggests that only small pots that were rapidly made (“crude wares”) were wheelthrown.

60 BERG 2009, 145 suggests that also on a macroscopic level it would be possible to distinguish between wheel-coiled and wheelthrown pottery but the most secure method is the X-Radiography ("in all cases, wheel-coiled vessels could always be firmly identified as such using X-radiography; they cannot be confused with the wheel-throwing technique"). She has also said that "thus wheel-coiled vessels can be identified by a mismatch between the X-ray image and macroscopic observations” (Berg 2009, 145).

61 Berg 2009, 143-144, Pl. 9.16. See also the catalogue entries on BERG 2009, 148-153, 156-157, 160-165 for examples of wheelthrown vases identified through X-Radiography (pots 12, 16, 23, 25, 27-28, 23, 38, 51, 53-55, 71-72, 75, 81, 84-85, 87, 92-93). For Phaistos, CALOI 2011 identifies macroscopically only the use of the wheel-throwing. 
Mainland Greece, Lindsay Spencer notes the existence of wheelthrown pottery next to wheel-coiled pottery in EBA and MBA Lefkandi and Asine, although she acknowledges the difficulty to identify macroscopically wheelthrown pottery. ${ }^{62}$ Maria Choleva, in turn, notices the exclusive use of wheel-coiling in central Greece and northeastern Peloponnese during EBA 2-3 i.e. the time when the potter's wheel first appeared in the Aegean. ${ }^{63}$

(b) On the other hand, there is a somewhat confusing discussion about the technical affordances of rotary devices used especially in Minoan Crete, the Aegean region from which the largest part of wheel fragments is coming. ${ }^{64}$ Instead of belonging to fast wheels (e. g. kick wheels), ${ }^{65}$ Minoan devices, as the archaeological data suggest, ${ }^{66}$ are associated with the type known as 'tournette', which is composed of a pivot disc rotating around an axis and reaching speeds not exceeding $100 \mathrm{rpm}^{67}$ Based on the abundant Minoan wheel remains, mainly clay wheel-heads, Don Evely and his colleagues have conducted different experiments to explore the mechanical properties of Minoan wheels. ${ }^{68}$ Based on experiments, it has been argued that the production of wheelthrown pottery is not exclusively dependent on the use of the fast wheel but can also be achieved by slow wheels $(60-80 \mathrm{rpm}){ }^{69}$ However, the experi-

62 Spencer 2007, 92-93, 120; 2010.

63 For macroscopic analysis of EBA wheelmade pottery see Choleva 2012; Choleva 2015, 468-493; Choleva 2020 b. For X-Ray analysis of the same material, see CHoleva 2020A. For the use of the same technique at MBA Vranas, Marathon, see CHOLEvA in press.

64 For a synthetic discussion, see Jefrra 2011, 44-53.

65 Rice 1987, 133-135, Fig. 5.9.

66 Knappett 1999, 116; JefFra 2011, 50-53; Berg 2013, $114-$ 116. For Minoan wheel typology, see Evely 1988; 2000. For an overview on the debate on the distinction about fast and slow wheels see Knappett 2004. For the suggestion concerning the presence of the kick wheel in Minoan Crete see Chatzi-Vallianou 1995, 1036-1046.

67 For an overview on evidence concerning the wheel devices in Minoan and Mycenaean period see BERG 2013, 114-116. For a recent synthesis of the archaeological evidence for wheel remains during the Bronze and Iron Ages in Greece, see HASAKi 2019, especially Fig. 12. For Egyptian tournettes called 'simple' wheels and related forming techniques see Arnold and Bourriau 1993, 44-84. For the experiments of Foster 1959 and those conducted by Berg see Berg 2013, 116, Tabs. 2-3. ments with such wheel-heads have demonstrated that wheel-throwing was possible only for small vessels and impossible for larger vessels. ${ }^{70}$ Those results are aligned with the conclusions drawn from experimental studies using other ancient tournettes found in $3^{\text {rd }}$ and $2^{\text {nd }}$ millennium Egypt and the Levant. ${ }^{71}$ These devices were suitable only for throwing smalls bowls (i.e. small lumps), while they are incompatible with centering and hollowing out heavier clay masses, i.e. larger pots. ${ }^{72}$ In addition, the experiments in the Levant have controlled the compatibility of tournettes with wheel-coiling methods and have shown that these devices were very effective in the rotation of coil-built pots of different shapes and dimensions. ${ }^{73}$

Contrary to Crete, no securely confirmed examples of turning devices are known from the Late Bronze Age contexts on the Greek mainland. ${ }^{74}$ Despite this lack of evidence, it is often assumed that Mycenaean potters used wheels of similar types like in Crete. ${ }^{75}$ At the Mycenaean settlement of Kontopigado, the frequent presence of pottery wasters within secondary deposits or dumps has been taken as evidence for the existence at this site of a pottery workshop that probably was in close connection to the Athenian Acropolis. ${ }^{76}$ Two finds have been interpreted in this respect as turning devices ${ }^{77}$, but this requires further investigation.

68 Evely and Morrison 2010; see also Morrison and Park 2007. For the classification of Minoan wheel-heads see Xanthoudides 1927 and Evely 1988; Evely 2000.

69 Evely and Morrison 2010, 285. For an overview but also for unpublished experiments see BERG 2013, 115-116.

70 Knappett 1999, 116; Berg 2013, 116-118.

71 Amiran and Shenhav 1984; Powell 1995; Roux and Miroschedji 2009.

72 For an overview of these studies see Roux and MiroschedJI 2009, 166; see also Pierret 1995, 29.

73 Roux and Miroschedji 2009, 166.

74 Wheel-heads of common Minoan types are reported from MH levels in Mycenae. See Hansen Streily 2000, 231. For an overview on the wheel remains in $\mathrm{MH}$ mainland Greece see BERG, 2013, 114-115.

75 BERG 2013, 116-117.

76 Kaza-Papageorgiou et al. 2011, 205, Fig. 3; see also Gilstrap et al. 2016.

77 Kaza-Papageorgiou et al. 2011, 206, Fig. 4.1; Kardamaki 2015A, 75, FIG. 14 (its exact location, on the floor of a court or inside the adjacent room $\mathrm{H}$, has to remain open, see Kardamaki 2015a, 52 fig. 4). Berg 2013, 114 for a summary on pottery kilns on the Greek mainland from $\mathrm{EH}$ to LBA. 
July Hruby has made detailed and very useful comments on the fabric, surface treatment and manufacturing techniques of the unpainted pots from the palace of Pylos but has expressed the opinion that the majority of the material was produced "off the hump". ${ }^{78}$ Christina Marabea has suggested that the Attic Mycenaean pottery from Kanakia on Salamis (dated to LH IIIC Early 1) was actually wheel-coiled. ${ }^{79}$ Also Berg did not exclude the possibility that in Mycenaean mainland like in Crete various wheel-based techniques were in use. ${ }^{80}$ Most recently, Bartłomiej Lis identified by means of macroscopic examination, among the material from room 60 at the palace of Pylos, the presence of both handmade and partially handmade (wheelmade) pottery. ${ }^{81}$ In some cases even the use of the paddle and anvil technique has been suggested. ${ }^{82}$

To sum up, the fact that the Mycenaean potters produced vessels according to different forming techniques has already begun to be recognized by some scholars, ${ }^{83}$ but the exact methods used for producing wheelmade pots were never investigated with an analytical tool such as X-Radiography combined with a detailed macroscopic examination. Moreover, the overall assumption that the largest part of the production is actually wheelthrown is still quite common, and this has not been questioned so far. This idea is so well rooted that some go so far to suggest that this may have been one of the main differences between the Mycenaean and Minoan/Minoanizing wares. ${ }^{84}$

\section{Methodology: identification of the wheel- based techniques}

Our study aims to address the question of forming techniques behind the wheelmade production during the Mycenaean period. For this purpose, a multiscale methodology has been developed in

\footnotetext{
Hruby 2006, 184.

Marabea 2012, 177 (wheel shaping/coiling).

Berg 2013, 117-118.

81 Lis 2016, 497-498, 507. Lis uses the term "wheelmade" independent of the exact method used, as opposed to "wheelthrown" signifying a pot thrown on the wheel from one piece of clay (Lis 2016, 497 n. 27).

$82 \quad$ Lis 2016, 498, Fig. 5; 507.

${ }^{83}$ See also Vitale 2018, 160-161, fig. 8.6 for the assemblages in Mitrou. The possible existence of wheelthrown pottery contemporary with pots produced by wheelfashioned techniques is suggested.
}

order to identify the complete production sequences, i.e. chaînes opératoires - the operational sequence of transforming raw materials into final objects ${ }^{85}$ which will here be distinguished on the base of specific ways (methods) of exploiting the potter's wheel in manufacture. ${ }^{86}$ Examining the wheelmade pottery in terms of chaînes opératoires and correlating the technical, morphological and stylistic characteristics of wheelmade pottery will allow exploring the craft behaviours enacting the wheelmade production.

More concretely, we have investigated the Mycenaean wheel-based technology by means of two complementary tools: macroscopic observation with X-Ray analysis. Our study will particularly focus on the identification of forming techniques and methods involved in the wheelmade pottery of Ayios Vasileios in Laconia where an extended macroscopic analysis of 169 vessels and vessels fragments bearing evidence of RKE followed by the X-Ray analysis of a selected sample of 14 pieces $^{87}$ have been conducted (see Tabs. 6-7). For purposes of comparison and in order to address wider questions about wheel usage in pottery production during the Mycenaean period, we conducted a complementary study of Argive pottery through the visual inspection of a small ceramic assemblage from Tiryns (26 vessels and vessel fragments) and visual examination combined with X-Ray analysis of selected finds (7 vessel fragments) found at Tall Zirā'a in Jordan (see Tabs. 12-13).

\subsection{Macroscopic analysis}

Independently of the technique used, the exploitation of RKE leaves a series of macro-features, such as concentric undulations, horizontal and parallel rilling, striations, symmetrical profiles and regular wall thickness. These traces were tradi-

\footnotetext{
4 Abell and Hilditch 2016, 166-

85 Schlanger 2005; For the chaîne opératoire approach see Roux 2009; 2011в. For the theoretical implications of the concept see Dobres and Horfmann 1994; Pigeot 2011.

86 For different case studies see Roux and Courty 2005; Roux 2009; Choleva 2020B.

87 Three more pieces coming from hand-made vessels have also been subjected to X-Ray analysis (a rim of pithos, a rim of jar and a body sherd with handle) but they will not be included in the present paper. Finally, two vessels from the group of the imported pottery were also examined via $\mathrm{X}$-Ray and will be presented elsewhere.
} 


\begin{tabular}{|c|c|l|l|}
\hline $\begin{array}{c}\text { Degree of wall } \\
\text { modification }\end{array}$ & Method & \multicolumn{1}{|c|}{ RKE features } & \multicolumn{1}{c|}{ Features of coil joins } \\
\hline \multirow{5}{*}{ Slight } & M1 & $\begin{array}{l}\text { Striations } \\
\text { Non-stretched clay walls }\end{array}$ & $\begin{array}{l}\text { No trace of coils on surface } \\
\text { Irregular relief } \\
\text { Uneven micro-topographies } \\
\text { Vertical/diagonal depressions Thickness } \\
\text { discontinuities }\end{array}$ \\
\cline { 2 - 4 } & M2 & $\begin{array}{l}\text { Striations } \\
\text { Rare rilling } \\
\text { Slight undulated surfaces } \\
\text { Slightly stretched clay walls }\end{array}$ & $\begin{array}{l}\text { Possible irregular wavy lines } \\
\text { Irregular micro-reliefs } \\
\text { Uneven micro-topographies } \\
\text { Thickness discontinuities }\end{array}$ \\
\hline \multirow{2}{*}{ Strong } & M3 & $\begin{array}{l}\text { Striations } \\
\text { Rilling/undulations in the form of bands } \\
\text { Stretched walls } \\
\text { Torsional strain and rippling }\end{array}$ & $\begin{array}{l}\text { Fissures along coil seams } \\
\text { Deep sub-parallel grooves }\end{array}$ \\
\cline { 2 - 5 } & M4 & $\begin{array}{l}\text { Striations } \\
\text { Regular rilling/undulations } \\
\text { Stretched clay walls } \\
\text { Torsional strain and rippling }\end{array}$ & $\begin{array}{l}\text { Parallel grooves } \\
\text { Ridges out of adjustment } \\
\text { Scalloped' profile (vertically) }\end{array}$ \\
\hline
\end{tabular}

Table 2 Main diagnostic macro-features of the four wheel-coiling techniques (based on Roux \& CourTy 19981998; JEFFRA 2011).

tionally interpreted as indicators for the wheelthrowing technique. ${ }^{88}$ However, Roux's work has revised the criteria previously used to identify this technique and has established a reference system drawn on experimental and archaeological data that enables the distinction between wheel-throwing and wheel-fashioning. ${ }^{89}$ The macroscopic analysis applied here follows the lines of this methodology and is founded on an elaborate system enabling the recognition of macro-features indicative of the manufacture of the roughout and the preform of a pot, and thus are suggestive of the primary and secondary forming techniques. ${ }^{90}$

More concretely, the identification of forming techniques is based on the observation and interpretation of those traces resulting from the operations on the clay and that are distributed over the surface, the topography and the break of the sherds. ${ }^{91}$ Despite the limitations of the visual inspection of the sherds, ${ }^{92}$ this system allows, in many instances, to distinguish the traces generated by the continuous pressures due to the use of RKE (i.e. concentric undulations, rilling, parallel

88 Roux 1994: 49-51; CourTy and Roux 1995, 16-17.

89 For a detailed presentation see Roux 2017, 101-121 with references.

90 Roux 2017, 167-250; see also Gosselain and LivingstoneSмith 2005. According to Roux's terminology, a "roughout" is "a hollow volume which does not present the final geometrical characteristics of the pot" whereas a preform is a pot "with its final geometrical characteristics but where the surface has not been (or will not be) subjected to horizontal striations, stretched clay walls, regular micro-topography, regular thickness), from those resulting from the presence of a handmade, e.g. coil-built, roughout (e.g. irregular reliefs and uneven micro-topographies corresponding to discontinuous pressures exerted on clay walls, and fissures and fractures on breaks and non rectilinear grooves (i.e. curving features) on surfaces corresponding to coil seams. ${ }^{93}$ In addition, the degree of wall modification of a coil-built roughout by RKE is an indicator for the operations during which the wheel enters the manufacturing process, and it is therefore suggestive of which wheel-coiling method applied. The idea is that the earlier the use of RKE, the stronger the elimination of hand-derived features and the stronger the wall modification under RKE. ${ }^{94}$ Consequently, pottery made by method 1 and 2 involving RKE only in final forming operations is characterized by relatively slight wall modification by RKE and preserves macrofeatures which are the result of discontinuous pressures applied during primary operations. On the contrary, pottery produced by methods 3 and 4

finishing techniques" (Roux and COURTY 1998, 763, appendix 1). The roughout is made by the so-called 'primary' forming techniques whereas the preform involves 'secondary’ forming techniques (RyE 1981, 1962).

91 Roux 2011b, 84; see also Choleva 2012, 112-130, tabs. 5-6.

92 Berg 2008, 1181; Berg 2009, 141.

93 Choleva 2012, 353-354, tabs. 5-6.

94 Roux 2017, 226-228. 
involving RKE since primary forming phases is characterized by a strong wall modification and is associated with more prominent RKE morphological qualities, such as undulations, intense rilling, and stretched clay walls (Tab. 2) ${ }^{95}$

\subsection{Microscopic analysis using $X$-Rays}

X-Radiography has become a standard method for the examination of the manufacturing techniques of prehistoric pottery and has the great benefit of being non-destructive. ${ }^{96}$ Although known and applied as early as the 1930s, the real potential of $\mathrm{X}$-Rays was recognized much later. ${ }^{97} \mathrm{X}$-Radiography produces detailed two-dimensional figures of the micro-structure of a pot, and together with an extended macroscopic analysis is essential for the reconstruction of the forming process. ${ }^{98}$ Rye was the first to introduce the main implications of $\mathrm{X}$-Radiography in ceramic studies by showing that the orientation of air voids and the alignment of inclusions in the clay matrix, created during the primary forming operations, was not affected or altered by secondary operations, and is thus conclusive for forming techniques. ${ }^{99}$ Despite its great potential, the X-Radiography ${ }^{100}$ has been very rarely used in the study of Aegean prehistoric pottery. There are some exceptions, namely Robert

95 Roux and Courty 1998, 746, tabs. 1, 3. For classification and description of the typology of RKE macro-traces, see JeFFrA 2011, 115-150; 2013, 7, tab. 2. For distinction of four methods, see also Choleva 2012, 353-358, tabs 7-8; see also RüCKL and JACOBS 2016. Despite some diagnostic traces, JEFFra 2013, 36 notes that the differentiation of method 4 from method 3 in small vessels is difficult. This was tested on experimental level by Berg but the sampled material has not been presented (BERG 2009).

96 Vandiver 1987; Carr 1990; Middleton 2005; LeVi and CAnnavò 2014; see Berg 2009, 137-138 for an overview.

97 Rye 1977. For description of the method see Pierret 1995, 51-81; Berg 2009, 140.

98 Pierret 1995, 37-50; Livingstone Smith 2007, 24-30; LivingSTONE Smith and Viseyrias 2010.

99 Rye 1977, 206; 1981, 61-62. For an overview of microtraces related to forming techniques see BeRg 2008, Fig. 1.

100 The accuracy of radiography in presenting the virtual composition of the object has a loss of about $30 \%$ (BERG $2009,143)$. For the variable parameters acting on the success of radiography see MidDLETon 2005. For a critical discussion on the problems of radiography see THÉr 2016, 214. For the potentials of X-Ray Computed Tomography (CT scanning) for getting 3D images of objects see LANG ET AL. 2005, 37; for recent applications in Aegean archaeology see Kozatsas et AL. 2018.
Johnston and Philip Betancourt on the EM III White-on-Dark east Cretan wares, Leonard et al. on a few Mycenaean stirrup jars found in Greece and in the Levant and finally Sara Levi and Valentina Cannavò on Mycenaean and Aegeanizing pottery from southern Italy. ${ }^{101}$ However, the biggest set of X-Ray data was recently produced by Berg who examined in this way 95 Minoan vessels dating from MM IB to LM IA. ${ }^{102}$ Berg was the first to introduce the distinction between wheel-throwing and wheel-coiling in the Bronze Age Aegean by elaborating the typology of micro-features established by Rye in the X-Ray analysis of pottery to investigate the Minoan ceramics from Knossos. ${ }^{103}$

According to Rye, the main criterion for discerning wheel-throwing, as opposed to hand-forming techniques, concerns the 'structural' porosity ${ }^{104}$ of the clay matrix. In the former case the non plastic and elongated air voids show a diagonal towards the rim orientation, when depicted in frontal view, and a parallel to the surface alignment in cross sections. Viewed from above, wheelthrown bowls present a spiral/circular orientation of elements. This distribution pattern is due to the application of vertical upwards and continuous gestures drawing the clay while turning. This results in the stretching and elongation of pockets of voids and their diagonal inclination. ${ }^{105}$ Rye also considered

101 Johnston and Betancourt 1984, 114-117, Pls. 9-10 (hand building techniques); LEONARD ET AL. 1993 produced X-ray images of three LH IIIA2 - IIIB stirrup jars found at Ialysos (Rhodes) and in the Argolid respectively. All three are Argive products according to chemical analyses by NAA (chemical group Mycenae/Berbati). These served as comparative material for finds from the Levant and Egypt, of which two Simple Style stirrup jars from Tell es-Sacidiyeh and a third stirrup jar from Gurob were examined by X-rays. Levi and Cannavò analyzed three Mycenaean imports and nine locally produced Mycenaean and Mycenaeanizing pots found at Broglio di Trebisacce in northern Calabria (Levi and Cannavò 2014, 365-368, fig. 5.1-5.2).

102 Berg 2008; 2009; Berg and Ambers 2011. Choleva (2020A) has recently studied 300 wheelmade and handmade pots/sherd from EBA mainland Greece.

103 Berg 2008, 1180-1181; 2009, 138, 143-146, fig. 1; Berg 2011: 58. For X-ray studies on wheel-fashioning techniques see VANDIVER 1987; PIERRET 1995.

104 For the distinction between structural voids and voids along assembled elements see Livingstone Smith and VisEYRIAS 2010, 131.

105 Rye 1977, 208; Rye 1981, 61-62, 79-80, Fig. 62 f-g; see also Pierret 1995, 113, 135-137; Thér 2016, 230-233, Figs. 5-7. 
the angle of the diagonally aligned inclusions/voids as indicative of the speed of the rotation: smaller angles suggest a slow lifting action whereas larger angles reaching $45^{\circ}$ witness faster rotation. ${ }^{106}$ However, the experiments conducted by Berg showed that this diagonal orientation could be achieved by both slow and fast rotations. ${ }^{107}$ This is an essential observation insofar as the various RKE techniques and methods may involve variably fluctuating speeds that, depending on the operations executed on the wheel, can affect, in variable ways, the arrangement of constituent elements in the clay matrix. ${ }^{108}$ Contrary to the wheelthrown pottery, according to Rye and Berg, the typical micro-features of a coil-built roughout are the horizontal alignment of elongated voids and inclusions in frontal view, their random orientation in cross section or, finally, in the case of bases viewed from above, their circular orientation. ${ }^{109}$ However, as other studies using X-Rays and CT scanning have shown, the porosities of coil-built roughouts can fluctuate from horizontal to random and the voids' shapes can vary from elongated to flattened/rounded depending on the pressures and their direction applied during joining coils. ${ }^{110}$ Coil seams, in turn, can be inferred either by a cluster of horizontally aligned inclusions on coil-seam zones ${ }^{111}$ or by elongated and shapeless voids indicating the air spaces between two coils that usually take the form of shapeless features. ${ }^{112}$

If the wheelthrown pottery displays a standard diagonal orientation of elongated elements and the coiled pottery presents randomly or horizontally aligned micro-features, what can be the expected distribution of the clay components of the wheelcoiled pots and to what extent can the typical microstructure of a coil-built roughout be altered by the different ways of exploiting the RKE. Considering the wheel's usage as a secondary forming technique not able to modify the microstructure of

\footnotetext{
106 RYE 1977, 208; 1981, 80.

107 Berg 2008, 1179-1180, 1180, Fig. 2; see also Pierret 1995, 113, 135-137; THÉR 2016, 235.

108 THÉR 2016, 230-233.

109 Rye 1981, 61-62, 68-69, Figs. 49a and 51; Berg 2009, 144. For the orientation of voids associated with other handbuilding techniques see Rye 1981; Pierret 1995; Kozatsas ET AL. 2018.

110 Thér 2016, 234; see also Kozatsas et Al. 2018.

111 Berg 2009, 143.

112 Berg 2009, 142-144; Livingstone Smith and Viseyrias 2010, 131. The coil seams as well as other micro-features
}

the coil-built roughout, Berg argued that the diagonal orientation of voids/inclusions is firm evidence for identifying wheelthrown pottery, while wheelcoiled pottery is characterized by horizontal void orientation. Based on experimental but limited data, she concluded that, at least, Roux's wheelcoiling methods 1 to 3 do not entail a modification of the initial orientation of coil porosities. ${ }^{113}$

However, other studies on the microstructure patterns of wheelmade pottery have disclosed a more complex picture. Roux and Courty, using scanning electron microscopy for characterizing the microstructure of experimentally wheelmade pots produced by the four wheel-coiling methods, have shown that the increasing use of RKE within the operational sequence has a wide-ranging impact on the configuration of the clay mass. According to these authors, methods 1 and 2 result in micro-structures slightly deformed by RKE, whereas method 3 and method 4 produce coil-built microstructures which are deformed by the use of the potter's wheel. This is caused by the increasing homogenization of the clay mass under the effect of RKE. ${ }^{114}$ Thér, in turn, who has analyzed thin sections under a petrographic microscope, and Pierret who analyzed via X-Rays experimental pottery, have demonstrated that the porosity of the clay mass is altered according to the degree of RKE exploitation. They both showed that while pots made by the wheel-coiling method 1 (shaping a coil-built roughout) preserve a rather horizontal distribution of clay components, the ones made by the wheel-coiling method 2 (thinning a coil-built roughout) start to present a deformation of clay micro-structures: the voids have the tendency to diagonally incline depending on the strength of the continuous pressures applied to each coil whereas coil seams appear as larger elongated voids indicative of stretching the air-voids during thinning on the wheel. ${ }^{115}$ This pattern is confirmed by the

areas, however, are not always visible or detectable on radiographic images because of the obscuring projection of a 3D-object in a 2D-image (KozATSAS ET AL. 2018, 104).

113 Berg 2008, 1181; Berg 2009, 143-145. Berg (2009, 145) suggests that the identification of method 4 is possible via $\mathrm{X}$-Radiography and she describes the alignment of voids and inclusions as "...a mixture of firmly horizontal and very lightly angled inclusions and void orientation”.

114 Roux and Courty 1998, 753-754, Tab. 4; Roux 2017, 114.

115 Thér 2016, 231, 233, Figs. 5 and 7; Pierret et AL. 1996, 436, Fig. 5. 


\begin{tabular}{|c|c|l|l|}
\hline $\begin{array}{c}\text { Degree of roughout } \\
\text { deformation }\end{array}$ & Method & \multicolumn{1}{|c|}{ RKE features } & \multicolumn{1}{|c|}{ Features of coils/joins } \\
\hline \multirow{2}{*}{ Slight } & M1 & $\begin{array}{l}\text { None RKE feature } \\
\text { Preservation of the initial orientation of } \\
\text { voids/inclusions }\end{array}$ & $\begin{array}{l}\text { Horizontal elongated/rounded voids } \\
\text { Rare horizontal and random shapeless fea- } \\
\text { tures/fissures } \\
\text { Thinned areas }\end{array}$ \\
\cline { 2 - 5 } & M2 & $\begin{array}{l}\text { Preservation of the initial orientation of } \\
\text { voids/inclusions } \\
\text { Rare slightly diagonal porosity }\end{array}$ & $\begin{array}{l}\text { Horizontal elongated/rounded voids } \\
\text { Rare larger shapeless voids } \\
\text { Thinned areas }\end{array}$ \\
\hline \multirow{2}{*}{ Strong } & M3 & $\begin{array}{l}\text { Diagonal orientation of voids/inclusions } \\
\text { Even alteration of thinned and thickened } \\
\text { zones (bands) }\end{array}$ & $\begin{array}{l}\text { Occasional horizontal orientation of voids/ } \\
\text { inclusions } \\
\text { Horizontal to strongly diagonal shapeless } \\
\text { to elongated voids } \\
\text { Occasional thinned areas }\end{array}$ \\
\cline { 2 - 5 } & M4 & $\begin{array}{l}\text { Diagonal orientation of voids/inclusions } \\
\text { Even alteration of thinned and thickened } \\
\text { zones (bands) }\end{array}$ & $\begin{array}{l}\text { Horizontal to strongly diagonal shapeless } \\
\text { to elongated voids }\end{array}$ \\
\hline
\end{tabular}

Table 3 Proposed diagnostic micro-features of the four wheel-coiling techniques (based on Pierret et al. 1996; Roux and CourTy 1998; BERG 2009; THÉr 2016).

results of a recent extended radiographic analysis of Early Bronze Age wheelmade pots from the Greek mainland: the stronger the implementation of RKE (methods 1 to 3 ) the more the voids exhibit a diagonal distribution. Interestingly, vessels presenting macroscopic features indicative of the wheel-coiling method 3 are also characterized by diagonally inclined elongated voids corresponding to coil-seams that had been radically deformed by RKE. ${ }^{116}$

In the light of these contradictory results, the actual data demonstrate complex modalities according to which a coil-built microstructure can be modified under RKE depending on the extent and nature of its exploitation in the forming process. It seems that when the wheel is used during the later stages of the forming process, the initial microstructure of coils is barely and variably modified by the subsequent use of RKE. On the contrary, when RKE is exploited effectively during the forming process, the microstructure of coils can be altered by the continuous and upwards pressures applied on the clay and thus the clay components can get a diagonal inclination. The fact that this diagonal pattern is not necessarily

\footnotetext{
116 ChOleVA 2020A.

117 Middleton 2005, 87; see also Rye 1981; Pierret 1995.
}

associated with the centering and hollowing of clay lumps, but, on the contrary, is due to the stretching of clay walls by RKE during joining and/or thinning operations, ${ }^{117}$ renders this kind of micro-feature equivocal and not a firm evidence for differentiating wheel-throwing from wheelcoiling - contrary to what Berg has argued. Moreover, since the coil-built roughout is, contrary to the wheelthrown lumps, a heterogeneous volume consisting of different elements worked separately during several forming operations, the microstructure generated under the homogenizing impact of RKE can present differentiation in the distribution of clay components throughout the entire clay matrix. Variables such as the stages and operations conducted with the wheel, the fluctuation of the wheel speed during the different operations, and the forces and their direction applied while working the different coils are factors impacting on the microstructure of each coil and thus on the overall configuration of the clay mass ${ }^{118}$. This could account for the differentiated organization of micro-features at different areas of the microstructure and for the different degrees of modification of each coil (Tab. 3).

\footnotetext{
118 Pierret 1995, 44-50; Courty and Roux 1995, 24-26; Roux and Courty 1998, 748-751; Berg 2009, 143-146.
} 


\section{Mycenaean Pottery Production}

\subsection{Mycenaean Pottery Production in Laconia}

An assemblage including 169 wheelmade vessels and fragments from Ayios Vasileios were selected after the visual inspection of the pottery from the site (see Tab. 6). After a detailed macroscopic examination and photographic documentation, a small part consisting of 14 samples was selected and submitted for X-Rays analysis. ${ }^{119}$ This assemblage contains a variety of vessels representative of the main morphological types revealing evidence of the wheel's use (see Tab. 7).

\subsubsection{The contexts and their dates}

The material from Ayios Vasileios treated in the present study derives from five different locations of the palace and dates from the latest LH IIIA1 to earliest LH IIIC Early (see Tabs. 6-7). Except for the pots from the destruction deposits on the floor of the stoas, the rest of the material derives from secondary deposits: terrace fills $(\Gamma 14 \beta)$ or other fills (foundation trench in $\Gamma 14 \beta$, Building B, layers above the court) and dumps (southeastern deposit, fresco dump). The vessels from Building B come from a room whose floor was not preserved. ${ }^{120}$

The majority of the examined finds come from the so-called southeastern deposit, a large dump to the south of the court dating to LH IIIA2 Early or LH IIIA2 Middle that yielded a large number of drinking cups. ${ }^{121}$ The terrace fill and the foundation trench in square $\Gamma 14 \beta$ contains some LH II but the latest sherds date to the latest LH IIIA1 and LH IIIA2 Early respectively. LH IIIA1 and LH IIIA2 Early are major palace construction phases during which the monumental court and the stoas were built. Pure LH IIB and LH IIIA1 deposits were rare in the area included in our study. The very few identified contexts of these phases yielded very fragmented material that did

119 Three pieces coming from hand-made vessels have also been submitted to X-Rays analysis (a rim of pithos, a rim of jar and a body sherd with handle) but we did not include them in the present paper focusing exclusively on wheelmaking techniques.

120 For the contexts see KARdAMAKi 2017.

121 Vasilogamvrou 2014, 64; Kardamaki 2017, 106-111.

122 For possible LH IIB fills and a LH IIIA1 pebble surface in Building B see KardamaKi 2017.

123 For these areas see Hachtmann forthcoming.

124 The LH IIIB2 Late material is not yet sufficient to provide this information. not allow any detailed examination. ${ }^{122}$ Even earlier deposits (MH III-LH IIA) are so far represented mainly in the area of the North Cemetery to the north of the court and are not included in this study. ${ }^{123}$ The latest Mycenaean phase identified at Ayios Vasileios (LH IIIC Early) is represented in this study by just one vessel, a deep bowl, that was examined only macroscopically.

The analysis of the finds led to the identification of several pottery wares. Regarding manufacturing techniques, a broad distinction was made between wheelmade and handmade wares. Manufacture on the wheel seems to be the dominant technique at Ayios Vasileios from LH IIB onwards and is commonly applied on fine painted and plain pottery and some cooking wares. ${ }^{124}$ Thus, wheelmade production is characteristic of the typical, everyday use pottery of Ayios Vasileios such as kylikes, cups and various bowls. ${ }^{125}$ Handmade pottery is, however, not at all uncommon during $\mathrm{LH}$ IIB and LH IIIA. One of the most characteristic handmade wares is the gritty ware that continues from MH III. After LH IIA the gritty ware is represented mainly by closed storage vessels, e.g. hydrias and jugs. Gritty ware drops from $13 \%$ in LH IIB ${ }^{126}$ to around $3-6 \%$ of the total rims in LH IIIA1 and LH IIIA2 Early and Middle. ${ }^{127}$ A second very common handmade pottery class consists mainly of tripods and button-based cooking jugs with schistose clay. Button-based cooking jugs represent typical $\mathrm{MH}$ cooking equipment but at Ayios Vasileios they seem to continue at least to LH IIIA2 Early. Finally, another group of handmade pots consists of coarse basins and pithoi. ${ }^{128}$

Most of the handmade and wheelmade wares identified in the material are frequent and assumed to be of local or more broadly Laconian production. ${ }^{129}$ However, some others have a distinct fabric that can be assigned macroscopically with relative confidence to production centres in Kythera (Red Silver Mica). Another fabric group closely resem-

\footnotetext{
125 In general, fine plain pottery dominates Ayios Vasileios assemblages from LH IIB to LH IIIB Middle while fine painted pottery (mainly monochrome and to a less extent pattern/linear painted) is rarer and encompasses around $10-20 \%$ of the fine wares. See also Kardamaki 2017.

126 KARDAMAKI 2017.

127 KARDAMAKi 2017. Some gritty hand-made goblets exist in LH IIB - LH IIIA2 contexts but these may be earlier pieces.

128 KARDAMAKi 2017.

129 RUtTER 2015 distinguishes between local, regional and supraregional production.
} 
bles pottery from south central Crete $\mathrm{e}^{130}$ and consists of coarse transport containers such as large wheelmade coarse-ware stirrup jars but also a few other handmade closed vessels. Some of the presumed Kytheran imports are handmade vessels. Finally, there is a group of medium coarse wheelmade closed vessels and cooking tripods made from a micaceous clay (Figs. 41.6, 42.3) that resembles that of Kytheran wares but is probably local.

Most of the material examined here by X-Ray or macroscopic analysis comes from fine painted and especially plain wheelmade wares and represents typical Mycenaean shapes of the phases LH IIIA1 and LH IIIA2 Early to LH IIIB2 Late, with only few examples belonging to wheelmade cooking wares (Tab. 7). ${ }^{131}$ These are conical cups FS 204 (Figs. 41.5, 42.1-2), carinated kylikes FS 267 (Fig. 41.2), rounded kylikes FS 264/266 (Fig. 41.1), goblets FS 263 (Fig. 40.1), cups FS 220 (Fig. 40.2), craters (Fig. 41.3), large and small angular bowls FS 295 (Fig. 41.4), and one painted deep bowl FS 284 (Fig. 40.5). There are also some small closed vessels such as an alabastron (Fig. 40.4) and finally vessels of special, possibly ritual function such as rhyta (Fig. 40.3). Among the most frequent wheelmade fine wares there is some variation in the material regarding surface finishing, colours and texture of the clay of the vessels. For example, the conical cup, one of the most common shapes in LH IIIA2, ${ }^{132}$ is the only shape that bears string-cutting marks underneath the base. The clay of the conical cups usually has more inclusions than other plain wares and is sometimes very micaceous. These differences may hint to products of different workshops within Laconia while for some pots and sub-wares a nonLaconian origin is also possible.

The only wheelmade coarse ware vessel examined by X-Ray analysis and presented here is a local Laconian cooking tripod (276AV/XRay sample 18). In terms of typology, it belongs to a hybrid type combining elements from both Kytheran and local cooking pots. ${ }^{133}$

\footnotetext{
130 Haskell et al. 2011; Kardamaki et al. 2016.

131 In this article, we are not discussing the handmade pots, which we have studied in the framework of our technology project. They will be the subject of a separate publication.

132 Kardamaki 2017. $12 \%$ of the plain rims from the $\mathrm{LH}$ IIIA2 fresco dump belongs to this shape.

133 See KARDAMAKi 2017, 104-105 for a similar cooking tripod of possible Kytheran provenance.
}

\subsubsection{Macroscopic examination}

The macroscopic analysis of the wheelmade pottery from Ayios Vasileios has revealed a great variability in macro-features indicative of forming operations. The most typical RKE evidence is the presence of a great variety of concentric parallel undulations in the form of bands running around the internal surfaces of the pots; their maintenance on the external surface is rare because of their obliteration by a secondary surface treatment. These undulations are usually deep and intense and are unevenly distributed along the surfaces. Their presence is due to continuous pressures applied to the clay during the roughing out stage (Fig. 1). The second typical macro-feature diagnostic of RKE comprises a variety of horizontal and rectilinear striations in the form either of fine to stacked rilling running around both internal and/or external surfaces or of incised grooves on the exterior. Their presence indicates a variable use of the wheel during final forming operations such as shaping the walls or treating the surfaces on the wheel (Fig. 2). Among the rarer RKE traces there are also wrinkles of the surfaces, a feature that results from compression operations during thinning and shaping (Fig. 3). String marks in the form of a variety of striations underneath the bases are also typical, indicating that some vessels have been removed from the wheel while rotating with the help of a string (semi-circular marks) whereas others were elaborated on the wheel when upside down (concentric marks) (Fig. 4).

Apart from those RKE-derived traces, however, a series of surface features reveal the presence of a coil-built roughout and thus the use of the wheel-coiling instead of wheel-throwing technique: the major part of the material $(81 \%$ of the examined pottery) provides clear indications of coil seams and discontinuous pressures. ${ }^{134}$ A firm evidence of coiling is the presence of elongated fissures in the section (breaks) along the coil joints (Fig. 5a-e). Coil seams are also sometimes visible

\footnotetext{
134 The rest of the studied material (19\%) does not present indications of coils. Given that the visibility of features on surfaces and breaks like coil seams is strongly contingent upon random factors, the absence of such traces is rather expected. However, these pots preserve, in their surfaces, RKE features which are identical with those observed on the identified wheel-coiled pottery. On account of these similarities, they should be considered as wheel-coiled instead of wheelthrown.
} 


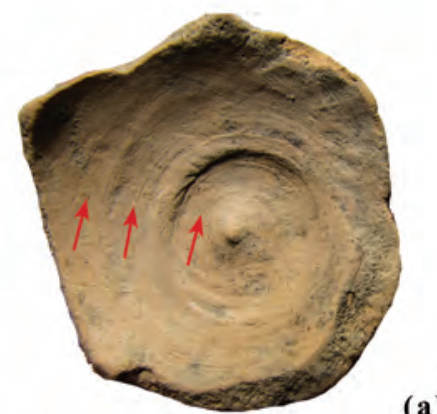

(a)
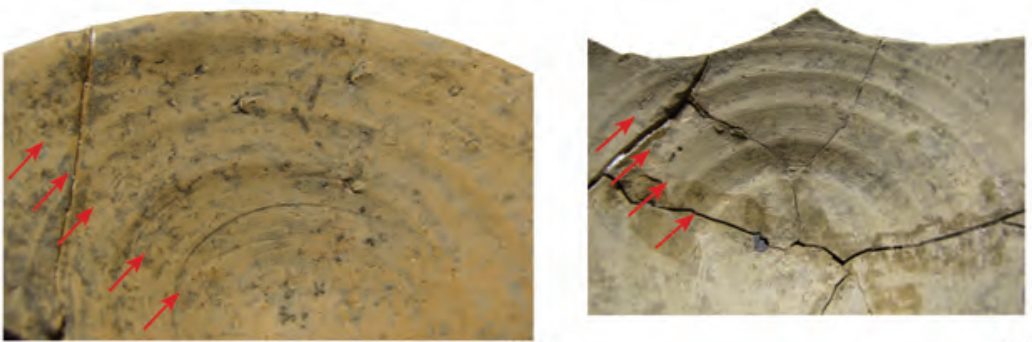

(b)

(c)

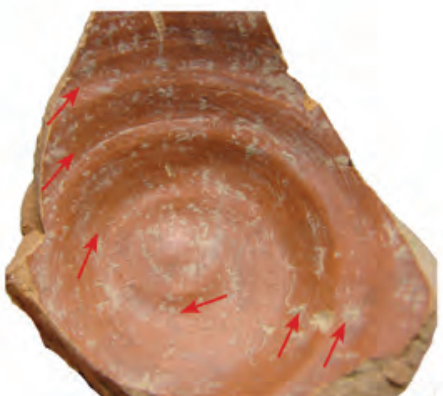

(d)

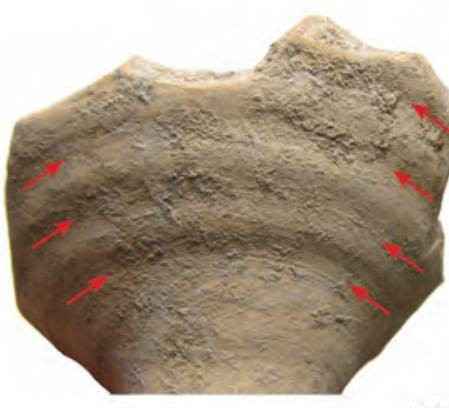

(e)

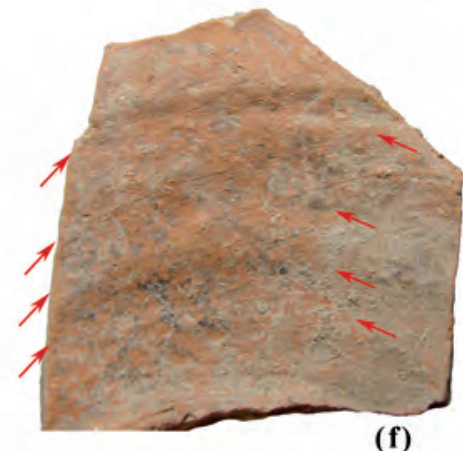

(f)

Fig. 1 Ayios Vasileios. Examples of concentric parallel undulations in the form of bands on internal/external surfaces: (a) 62AV; (b) 1AV; (c) 3AV; (d) 194AV; (e) 71AV; (f) 96AV (Photos by M. Choleva)

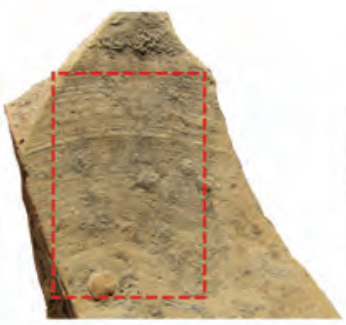

(a)

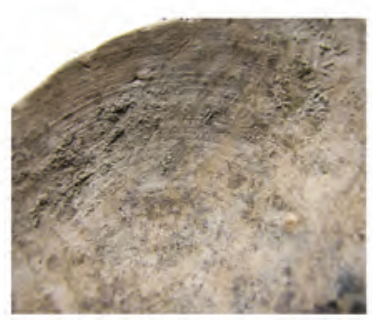

(b)

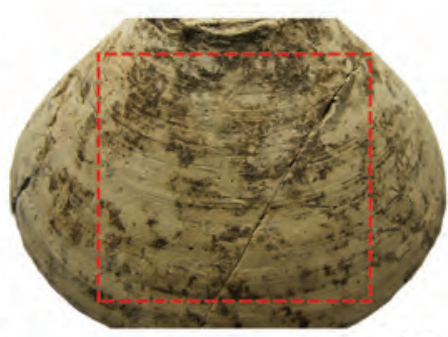

(c)

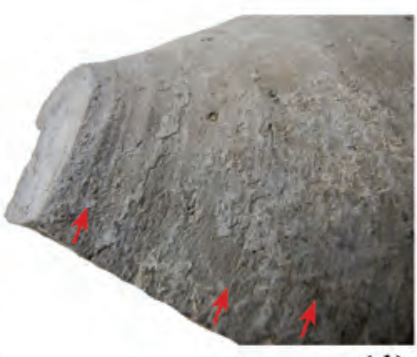

(d)

Fig. 2 Ayios Vasileios. Examples of horizontal and rectilinear striations on internal/external surfaces: (a) 7AV; (b) 43AV; (c) 2AV; (d) 268AV (XRay sample 9) (Photos by M. Choleva)
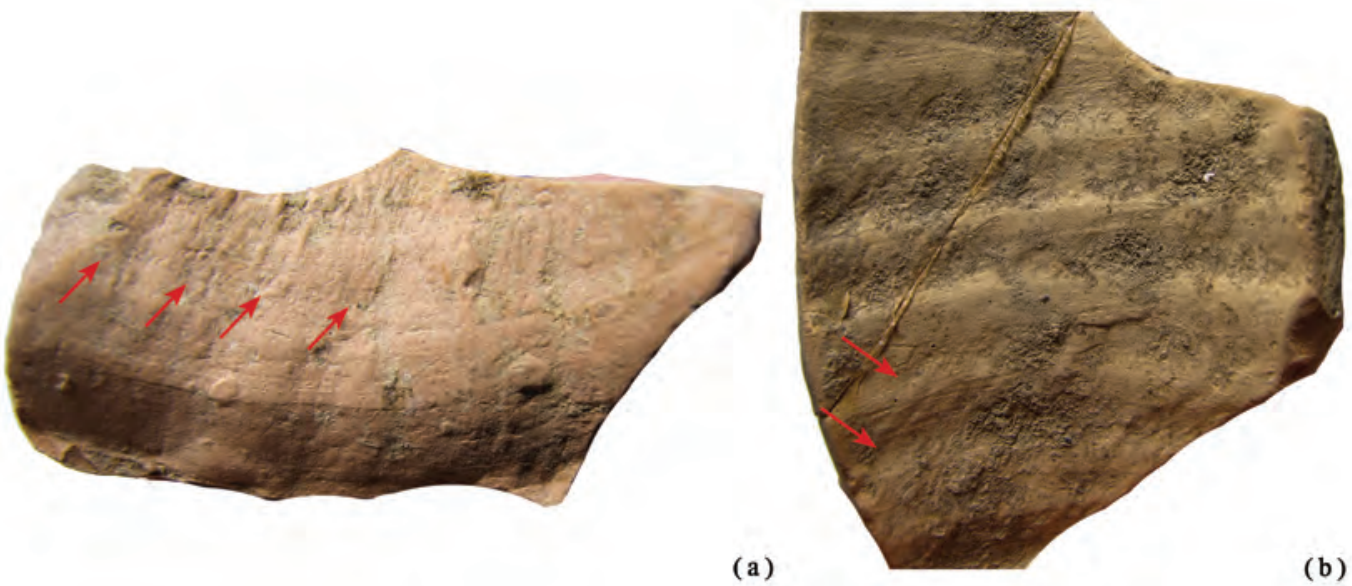

Fig. 3 Ayios Vasileios. RKE-derived compression ripples on internal surfaces: (a) 180AV; (b) 55AV (Photos by M. Choleva) 
on surfaces in the form of oblique and small shapeless 'hollowed' features or non-rectilinear or wavy deep grooves (Fig. $\mathbf{5 f}-\mathbf{h})$. Micro-variations in wall thicknesses (Fig. 6a-b) and uneven microtopographies along the horizontal or vertical axis (Fig. 6c) are also indicative of assembled elements and of discontinuous pressures applied during the joining of coils and thinning of the roughout. Finally, coiling is sometimes indicated by preferred breaks along the junctions of assembled coils (Fig. 7). A few pots also exhibit long, parallel to the surface, fissures visible in the
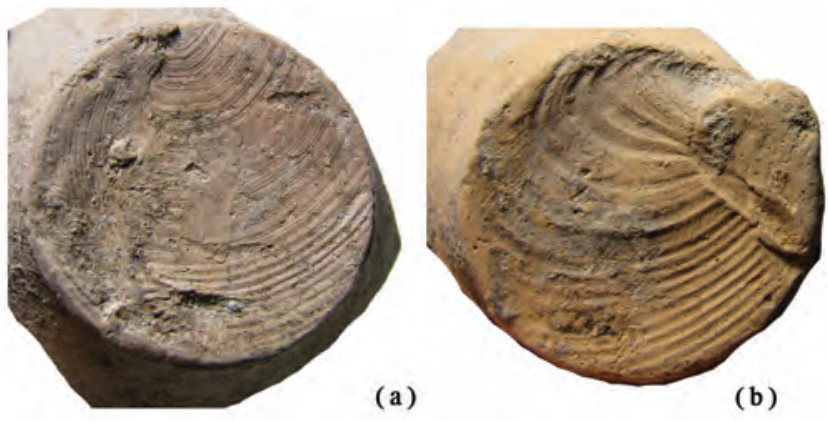

(b)

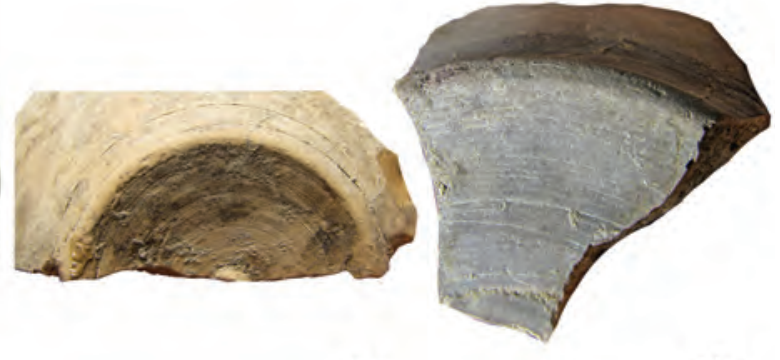

(c)

(d)

Fig. 4 Ayios Vasileios. Variety of striations underneath the bases: (a) 87AV; (b) 139AV; (c) 13AV; (d) 181AV

(Photos by M. Choleva)
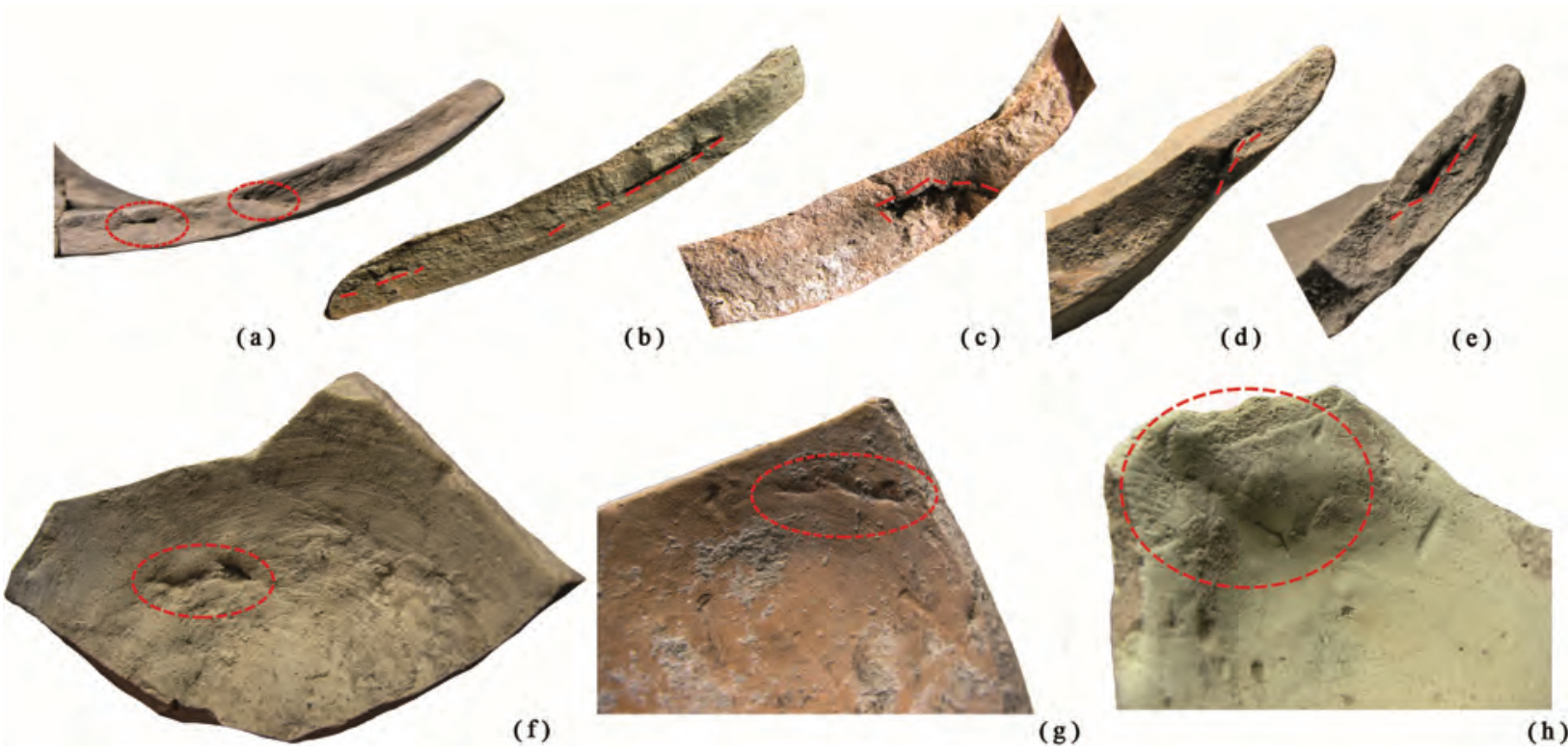

Fig. 5 Ayios Vasileios. Variety of coil seams visible on surfaces and breaks: (a) 202AV; (b) 48 AV; (c) 105AV; (d) 7AV; (e) 71AV; (f) 198AV; (g) 87AV; (h) 156AV (Photos by M. Choleva)

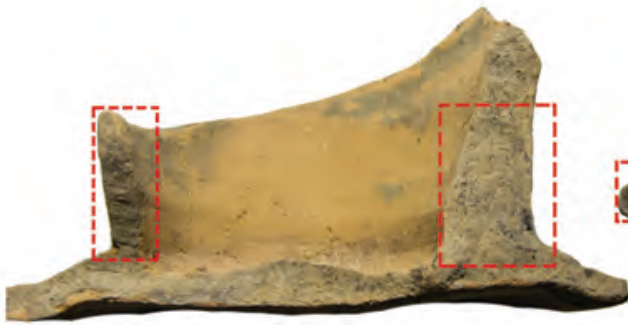

(a)

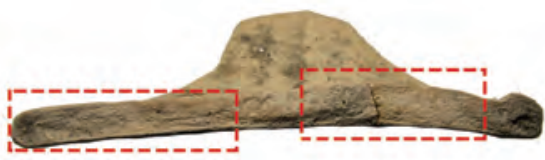

(b)

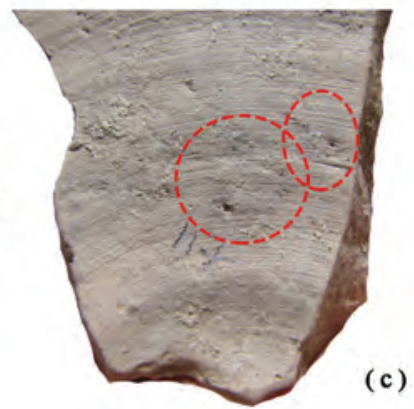

(c)

Fig. 6 Ayios Vasileios. Micro-variations in wall thicknesses and uneven micro-topographies: (a) 148AV; (b) 55AV; (c) 10AV (Photos by M. Choleva) 

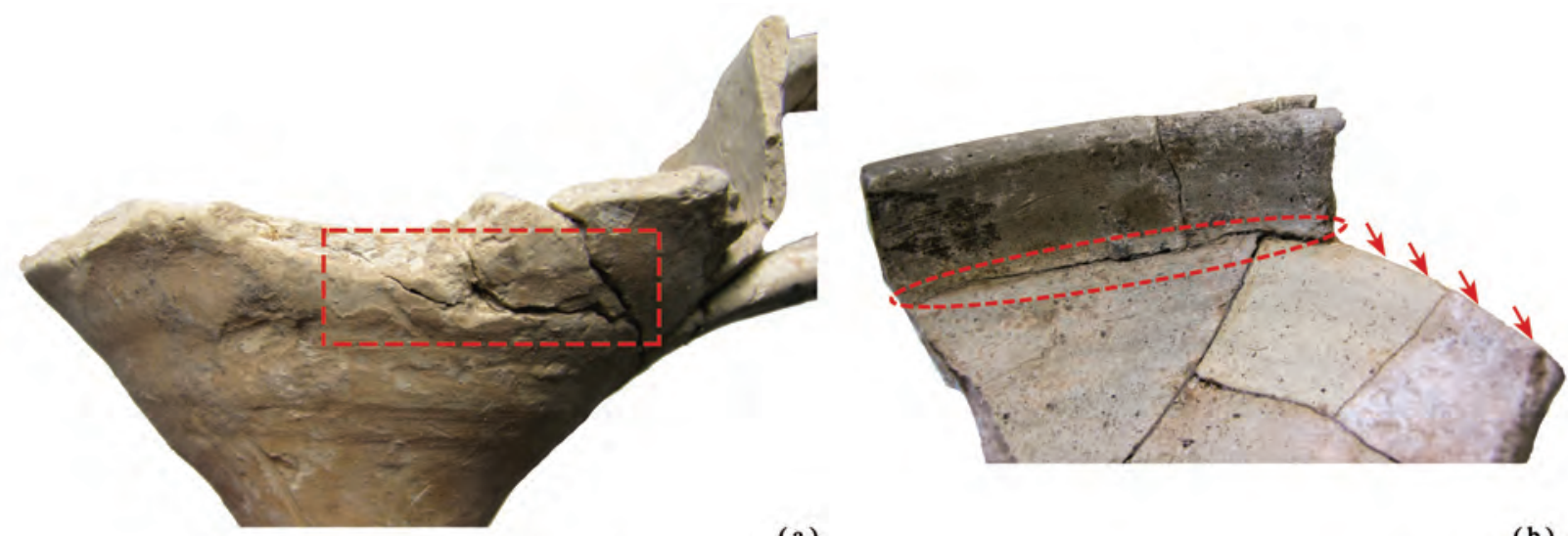

(a)

(b)

Fig. 7 Ayios Vasileios. Preferred breaks on the weak zones of assembled coils: (a) 157AV; (b) 274AV (Photos by M. Choleva)

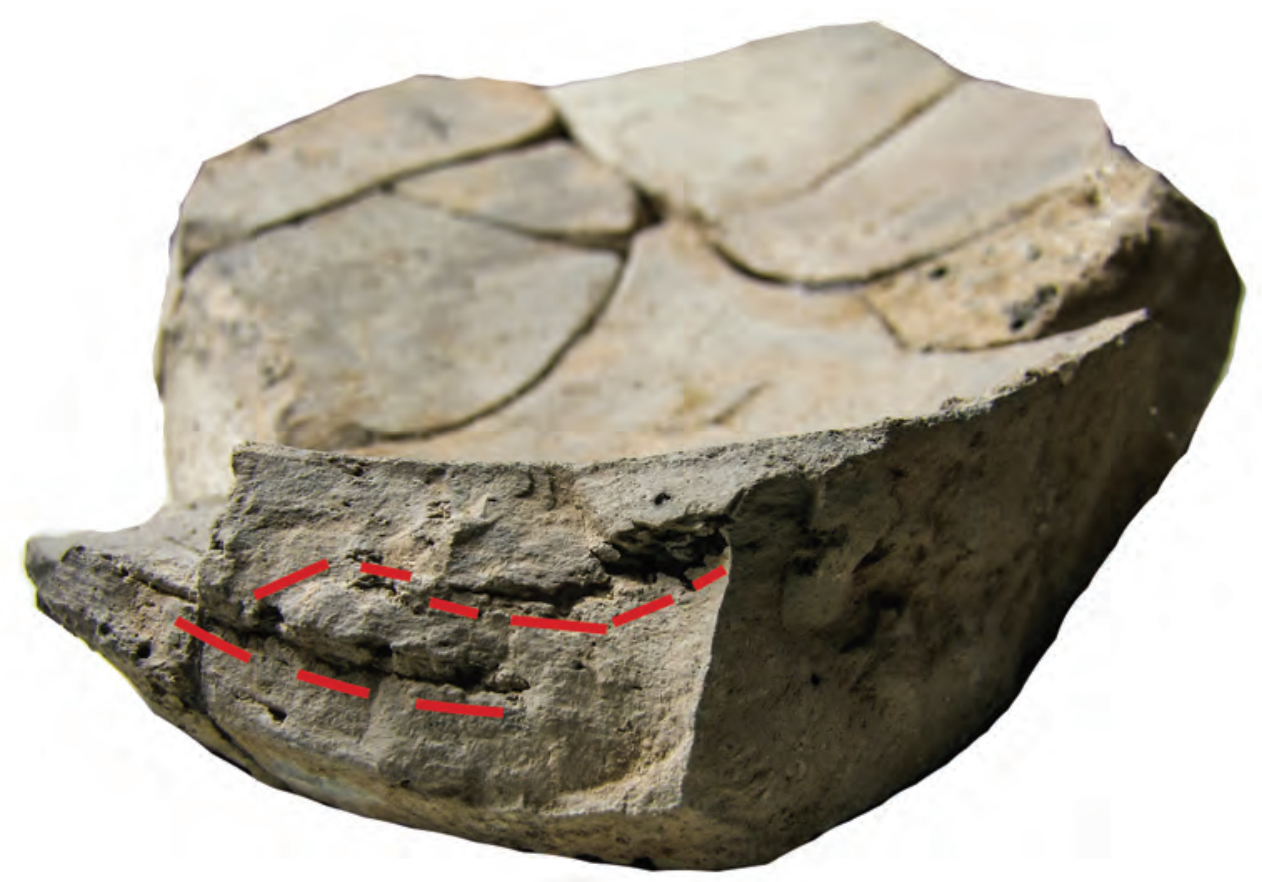

Fig. 8 Ayios Vasileios. Joint slabs on the section of the base of the sherd 174AV (Photo by M. Choleva)

sections of the bases that might indicate slabs instead of coils being used for the formation of bottoms (Fig. 8).

\subsubsection{X-Ray analysis}

The radiographic analysis of a selected sample of wheelmade pots has confirmed the results of the macroscopic examination: it has not provided any evidence for wheel-throwing and has demonstrated that the wheel-coiling technique is typical of the wheelmade pottery at Ayios Vasileios. The majority of the samples feature a diagonal orientation of voids that are dispersed throughout the clay matrix, while alignment is usually circular on bases when viewed from above (Fig. 9). However, in many cases, the diagonal distribution of voids is "disturbed" by restricted areas with horizontally and randomly distributed elongated and flattened voids suggesting specific coil-built zones that were not affected by RKE (Fig. 10). Very few pots are characterized exclusively by horizontally and randomly oriented porosities, suggesting a roughout not modified by RKE (Fig. 11). In some sherds/ pots, mainly made in coarser fabrics, the orientation of voids is hardly visible. The voids between joined coils are distinguished from the 'structural' voids by their morphology and the manners of 


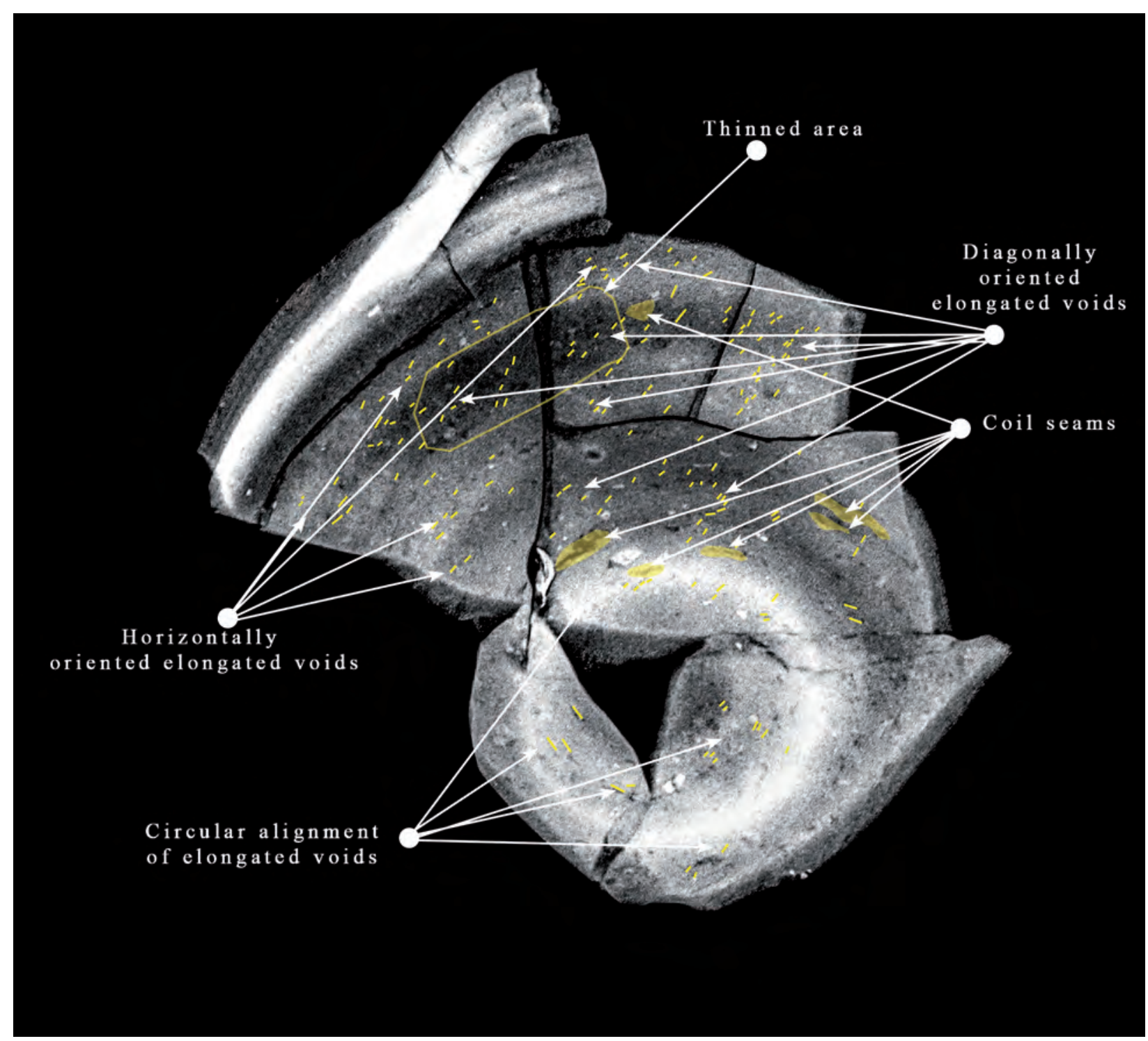

Fig. 9 Ayios Vasileios. Diagonal and circular orientation of 'structural' voids observed in 274AV (XRay sample 16) (XRay by I. Basourakos, medical center Sparta)

their distribution throughout the clay matrix. More specifically, coil seams are indicated by air pockets appearing in the forms of shapeless, non-rectilinear and often oblique or horizontal elongated fissures with sharp to diffuse boundaries ${ }^{135}$. Voids along coil seams are either scattered unevenly over the clay matrix or parallel along the horizontal axis, thus indicating a sub-parallel succession of assembled coils. Their orientation is either random or, in some cases, diagonal following the overall distribution pattern of 'structural' voids

135 See Livingstone Smith and Viseyrias 2010, 131, fig. 12 for comparison.

136 It is noteworthy that the visible coil seams are fewer than expected and, in many cases, joints visible macroscopical-
(Fig. 12). ${ }^{136}$ As regards the direction of inclusions that are usually rounded, they are mostly distributed randomly without presenting a clear orientation pattern. When they are elongated, they are sometimes characterized by either a predominantly diagonal or predominantly horizontal orientation. Diagonally aligned inclusions are usually combined with diagonal void's orientations and reveal the effect of RKE use (Fig. 13). In few cases, occasional darker areas indicate a variation of the wall thickness and reveal zones of assembled coils

ly are totally invisible in X-Ray images. This is due to three probable factors: the very efficient joining of coils and the homogenizing impact of RKE on coil-built areas as well as the obscuring effect of $2 \mathrm{D}$ images. 


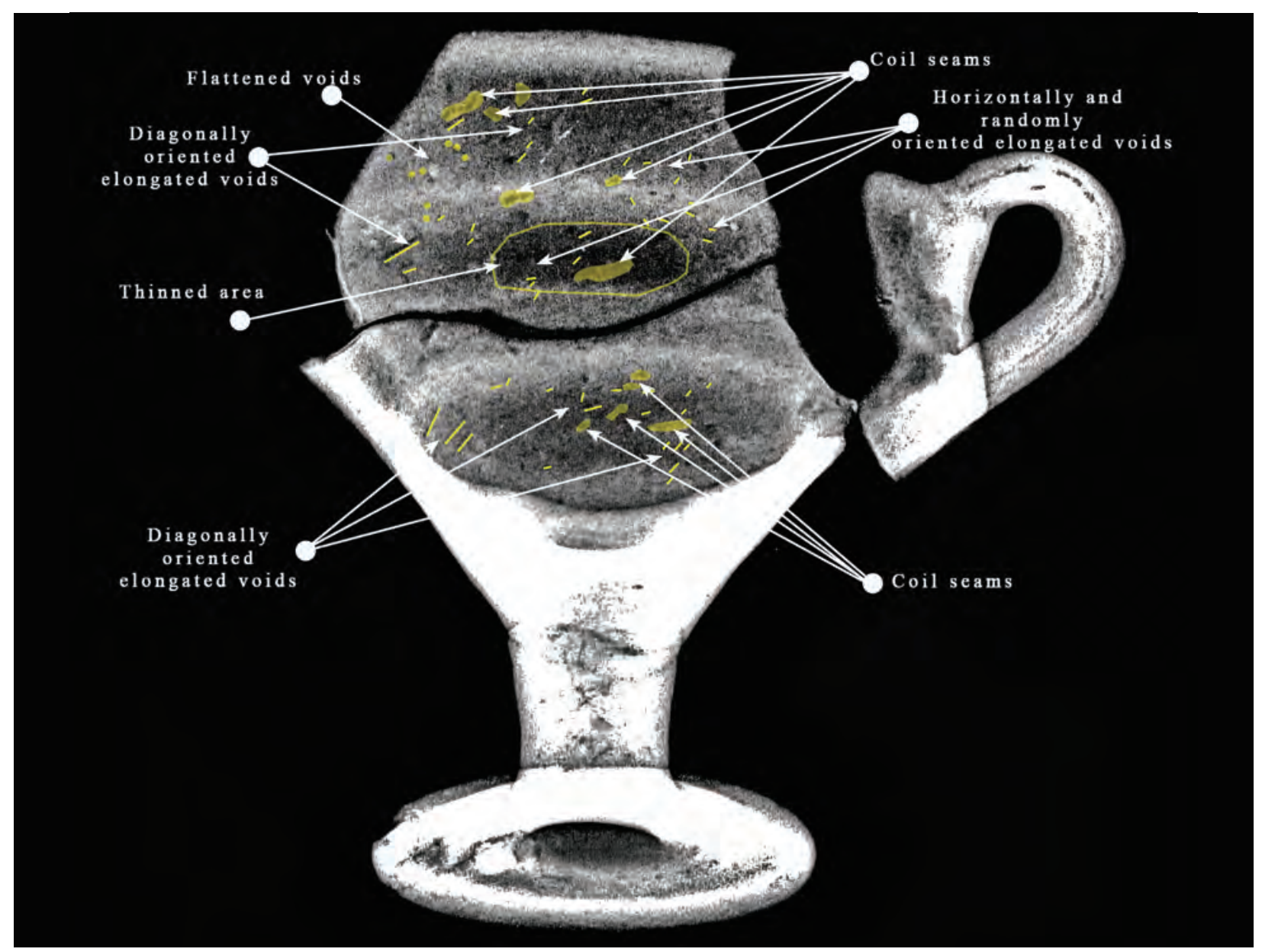

Fig. 10 Ayios Vasileios. Coexistence of diagonally, horizontally and randomly oriented 'structural' voids observed in 269AV (XRay sample 10) (XRay by I. Basourakos, medical center Sparta)

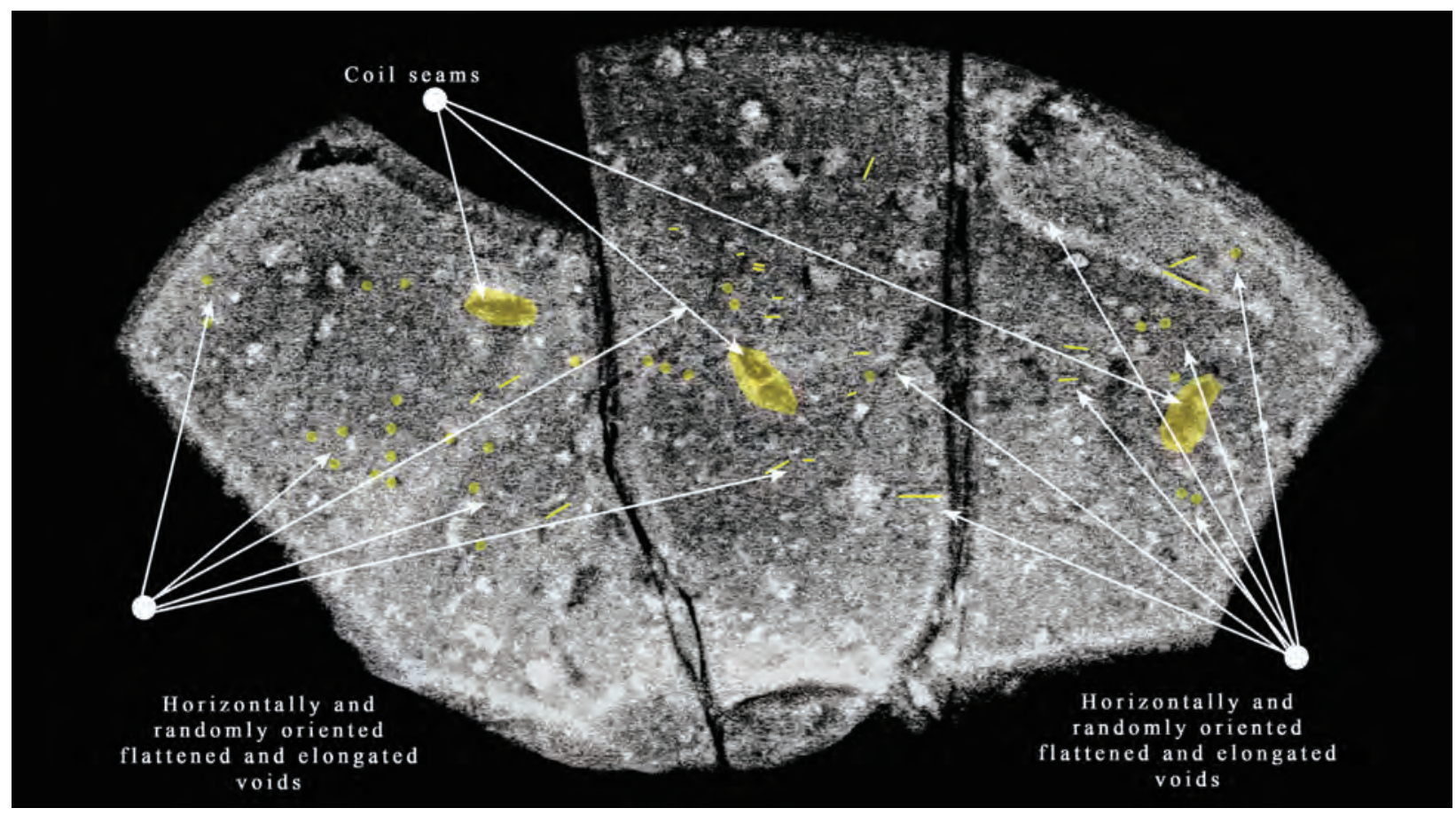

Fig. 11 Ayios Vasileios. Horizontally and randomly distributed 'structural' voids observed in 267AV (XRay sample 8) (XRay by I. Basourakos, medical center Sparta) 
to which discontinuous pressures have been applied during coiling (see Fig. 12b). Supplementary evidence for wheel-coiling is the irregular alteration of thinned (darker) and thickened (lighter) bands which corresponds to coils of different thickness regularized by RKE (see Figs. 9-10, 12).

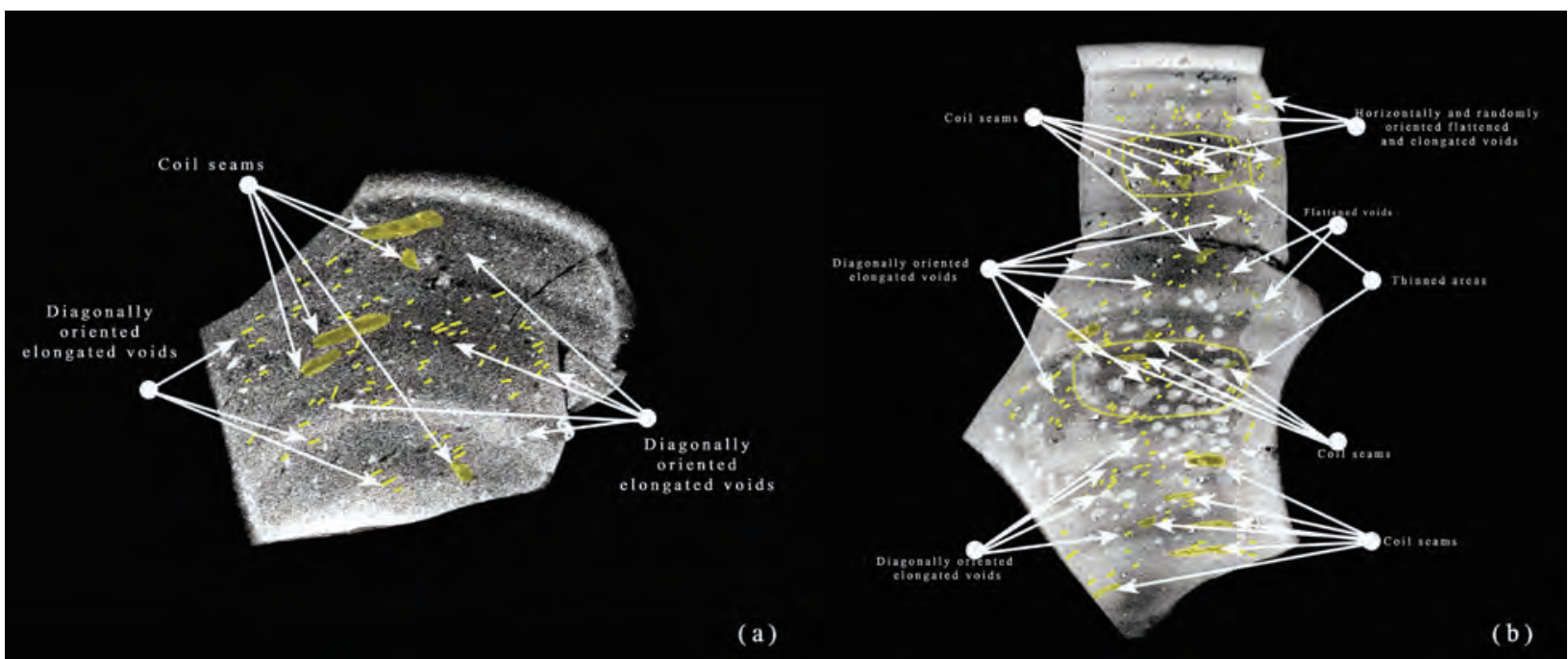

Fig. 12 Ayios Vasileios. Different types of elongated fissures and voids along coil seams observed in (a) 273AV (XRay sample 14) and (b) 261AV (XRay sample 2) (XRay by I. Basourakos, medical center Sparta)

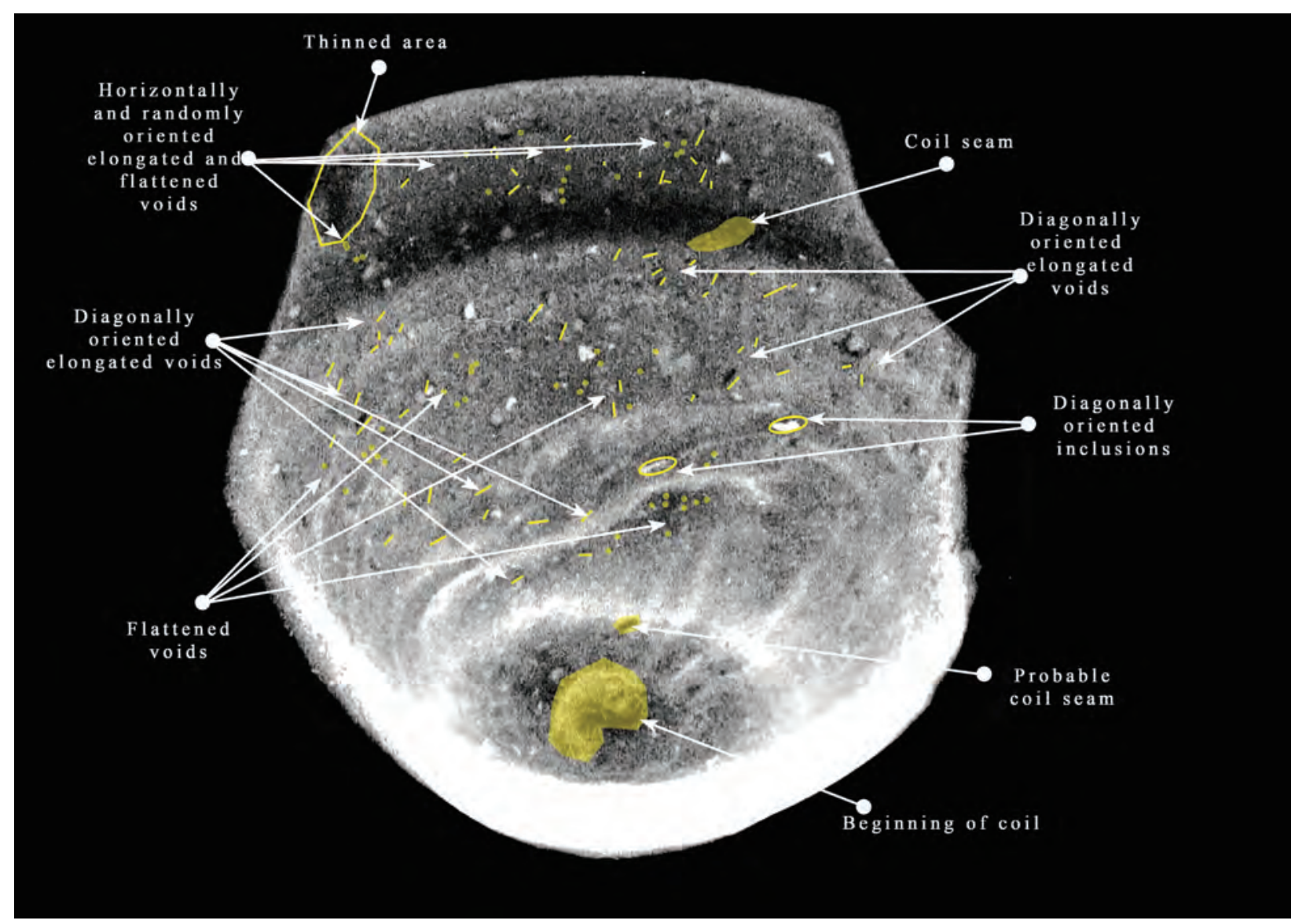

Fig. 13 Ayios Vasileios. Diagonally aligned inclusions observed in 264AV (XRay sample 5) (XRay by I. Basourakos, medical center Sparta) 
4.1.4. Degrees of roughout modification and wheel-coiling methods

Both macro- and micro-features were conclusive for the degree of roughout modification by RKE suggesting two main different ways of using the wheel during the forming operations (Tab. 4-5).

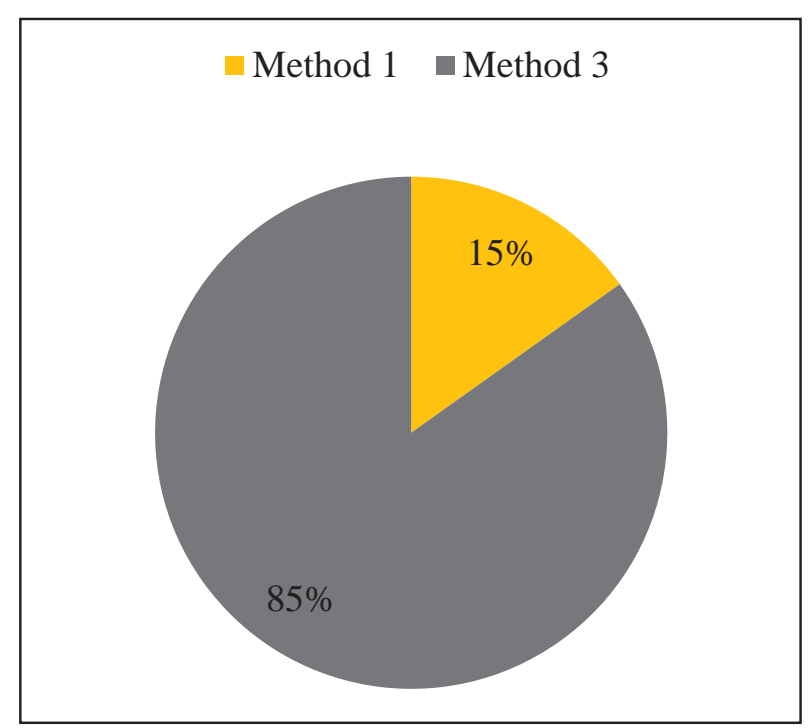

Table 4 Ayios Vasileios. Distribution of identified methods in the macroscopically examined assemblage

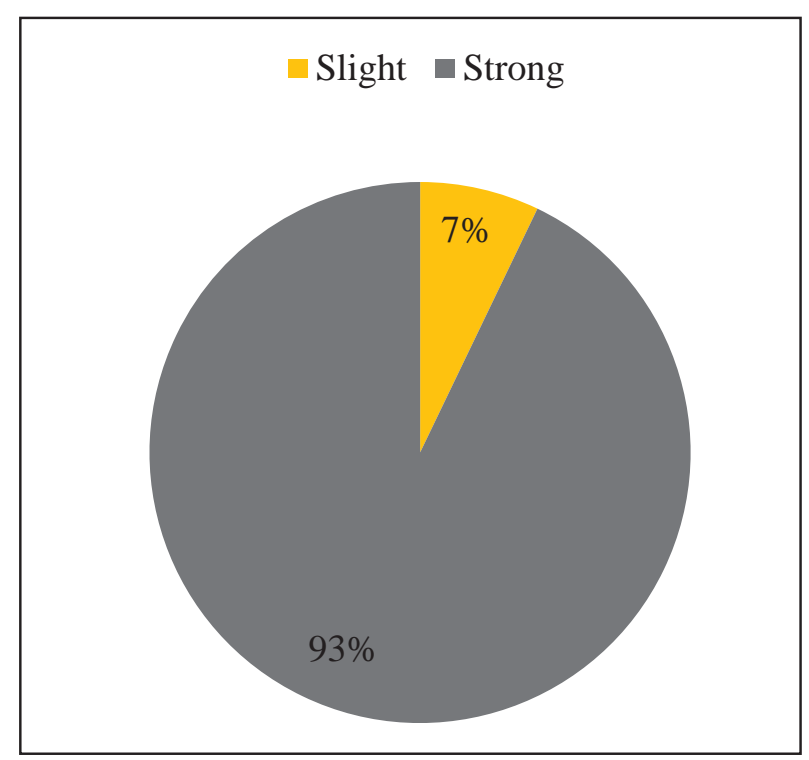

Table 5 Ayios Vasileios. Degrees of wall modification by RKE identified in the microscopically examined assemblage

Coil-built roughouts strongly deformed by RKE The major part of the examined material shares macroscopically a homogeneous visual 'appearance' characterized by strongly undulated exterior/ interior surfaces along with rilling, stretched clay walls, regular thickness variations and even reliefs that are indicative of a strong modification of the roughout under the impact of RKE and therefore of an extensive exploitation of the wheel during primary forming operations. Those pots/sherds present characteristic macro-features, which might be ascribed to what Roux and Courty have called wheel-coiling method 3. From the radiographic point of view, this material is characterized by a regular alteration of darker and lighter bands corresponding to undulations as well as a diagonal orientation of voids distributed over the clay matrix. These micro-features suggest continuous upwards pressures on the clay during the construction of the walls. Horizontally and randomly aligned voids, which occur locally at particular spots, disclose those coil's parts whose microstructure has not been affected by RKE. The presence of these horizontal voids among the diagonal ones suggests the fluctuation of rotational speed as well the alteration of different pressures exerted on the different coil-built areas during the operation of joining. In addition, the occurrence of sporadic irregular thinned areas suggests the local application of discontinuous or stronger continuous pressures on specific zones along assembled coils. The entire set of micro-features suggest, conclusively, a strong modification of the roughout by RKE, while at the same time the diminished homogeneity of the clay mass reveals the use of the wheel since the operation of joining the coils as a component of the primary forming technique employed.

\section{Coil-built roughouts slightly deformed by RKE}

A minor part of the examined material provides evidence of slight modification of walls, indicative of what Roux and Courty have described as wheel-coiling method 1 . Those pots/sherds are characterized by non-stretched clay walls, differential surface morphologies, irregular wall thickness and uneven reliefs due to discontinuous pressures applied while joining the coils and thinning the walls without RKE. The use of the wheel is only confirmed by macro-features such as horizontal and rectilinear striations, rare slightly undulated surfaces corresponding to coils that have been created during the final operations of shaping the roughout by RKE. The pots providing such macro-features are discerned by the prominent horizontal and random orientation of voids/inclusions. This kind of distribution implies different types of discontinuous pressures for joining coils 
Table 6 Chaînes opératoires identified at Ayios Vasileios through macroscopic examination and X-Ray analysis. For description of contexts see KARDAMAKI 2017

\begin{tabular}{|c|c|c|c|c|c|c|}
\hline Chaîne & $\begin{array}{l}\text { Roux's } \\
\text { method }\end{array}$ & Shape & Category & Context & Chronology & Total \\
\hline \multirow{23}{*}{ LAC1 } & M3 & Goblet FS 263 & Fine painted & $\begin{array}{l}\text { Southeastern deposit, } \\
\text { Foundation Trench } \Gamma 14 \beta\end{array}$ & $\begin{array}{l}\text { LH IIIA1/LH AIII2, LH } \\
\text { IIIA2 Middle }\end{array}$ & 10 \\
\hline & M3 & $\begin{array}{l}\text { Globular kylix } \\
\text { FS } 264\end{array}$ & Fine painted & Southeastern deposit & LH IIIA2 Middle & 1 \\
\hline & M3 & Crater/goblet & Fine painted & Southeastern deposit & LH IIIA2 Middle & 1 \\
\hline & M3 & Kylix/goblet & Fine painted & Foundation Trench $\Gamma 14 \beta$ & LH IIIA1/LH III2 & 1 \\
\hline & M3 & $\begin{array}{l}\text { Alabastron } \\
\text { FS 84/85 }\end{array}$ & Fine painted & Southeastern deposit & LH IIIA2 Middle & 1 \\
\hline & M3 & Closed shapes & Fine painted & $\begin{array}{l}\text { Southeastern deposit, } \\
\text { Foundation Trench } \Gamma 14 \beta\end{array}$ & $\begin{array}{l}\text { LH IIIA1/LH III2, LH } \\
\text { IIIA2 Middle }\end{array}$ & 6 \\
\hline & M3 & $\begin{array}{l}\text { Cups } \\
\text { FS 219/220 }\end{array}$ & Fine painted & Southeastern deposit & LH IIIA2 Middle & 2 \\
\hline & M3 & $\begin{array}{l}\text { Conical bowl } \\
\text { FS 290/300/301 }\end{array}$ & Fine painted & Building B & LH IIIA2 Early & 1 \\
\hline & M3 & Deep bowl FS 284 & Fine painted & $\begin{array}{l}\text { Post-destruction layers } \\
\text { above court }\end{array}$ & $\begin{array}{l}\text { LH IIIB2 Late/LH IIIC } \\
\text { Early }\end{array}$ & 1 \\
\hline & M3 & Miscelaneous/open & Fine painted & $\begin{array}{l}\text { Foundation Trench } \Gamma 14 \beta \\
\text { Southeastern deposit, } \\
\text { Building B }\end{array}$ & $\begin{array}{l}\text { LH IIIA1/LH III2-LH } \\
\text { IIIA2 Late }\end{array}$ & 3 \\
\hline & M3 & Rhyton FS 199 & Fine painted & Southeastern deposit & LH IIIA2 Middle & 2 \\
\hline & M3 & Kylix FS 267 & Fine Plain & $\begin{array}{l}\text { Southeastern deposit, } \\
\text { Building B, Fresco dump }\end{array}$ & $\begin{array}{l}\text { LH IIIA2 Middle-LH } \\
\text { IIIA2 Late }\end{array}$ & 16 \\
\hline & M3 & Kylix FS 264/266 & Fine Plain & $\begin{array}{l}\text { Southeastern deposit, } \\
\text { Foundation Trench } \Gamma 14 \beta\end{array}$ & $\begin{array}{l}\text { LH IIIA2 Early-LH IIIA2 } \\
\text { Late }\end{array}$ & 2 \\
\hline & M3 & $\begin{array}{l}\text { Kylix-bases and } \\
\text { kylix-stems }\end{array}$ & Fine Plain & $\begin{array}{l}\text { Southeastern deposit, } \\
\text { Foundation Trench } \Gamma 14 \beta \text {, } \\
\text { Building B, Fresco dump }\end{array}$ & $\begin{array}{l}\text { LH IIIA1/LH III2-LH } \\
\text { IIIA2 Late }\end{array}$ & 48 \\
\hline & M3 & Goblet/kylix & Fine Plain & Southeastern deposit & LH IIIA2 Middle & 1 \\
\hline & M3 & Goblet FS 263 & Fine Plain & $\begin{array}{l}\text { Southeastern deposit, } \\
\text { Fresco dump }\end{array}$ & $\begin{array}{l}\text { LH IIIA2 Middle-LH } \\
\text { IIIA2 Late }\end{array}$ & 4 \\
\hline & M3 & $\begin{array}{l}\text { Angular bowl } \\
\text { FS } 295\end{array}$ & Fine Plain & $\begin{array}{l}\text { Southeastern deposit, } \\
\text { Fresco dump, south stoa }\end{array}$ & $\begin{array}{l}\text { LH IIIA2 Middle-LH IIIB } \\
\text { Middle }\end{array}$ & 5 \\
\hline & M3 & Con. cup FS 204 & Fine Plain & $\begin{array}{l}\text { Southeastern deposit, } \\
\text { Foundation Trench } \Gamma 14 \beta \text {, } \\
\text { Building B, Fresco dump }\end{array}$ & $\begin{array}{l}\text { LH IIIA1/LH IIIA2-LH } \\
\text { IIIA2 Late }\end{array}$ & 23 \\
\hline & M3 & $\begin{array}{l}\text { Crater (horizontal } \\
\text { and vertical handles) }\end{array}$ & Fine Plain & $\begin{array}{l}\text { Southeastern deposit, } \\
\text { Fresco dump, }\end{array}$ & $\begin{array}{l}\text { LH IIIA2 Middle-LH } \\
\text { IIIA2 Late }\end{array}$ & 5 \\
\hline & M3 & Dipper FS 236 & Fine Plain & Southeastern deposit & LH IIIA2 Middle & 1 \\
\hline & M3 & Open shape & Fine Plain & $\begin{array}{l}\text { Southeastern deposit, } \\
\text { Fresco dump }\end{array}$ & $\begin{array}{l}\text { LH III2 Middle-LH IIIA2 } \\
\text { Late }\end{array}$ & 2 \\
\hline & M3 & Closed shape & Fine Plain & $\begin{array}{l}\text { Southeastern deposit, south } \\
\text { stoa }\end{array}$ & $\begin{array}{l}\text { LH IIIA2 Middle-LH IIIB } \\
\text { Middle }\end{array}$ & 2 \\
\hline & M3 & $\begin{array}{l}\text { Flat based cooking } \\
\text { jug, cooking rims, } \\
\text { lamp }\end{array}$ & $\begin{array}{l}\text { Plain Medium } \\
\text { Coarse/cooking }\end{array}$ & $\begin{array}{l}\text { Southeastern Deposit, } \\
\text { Fresco dump }\end{array}$ & $\begin{array}{l}\text { LH IIIA2 Middle, LH } \\
\text { IIIA2 Late }\end{array}$ & 4 \\
\hline
\end{tabular}




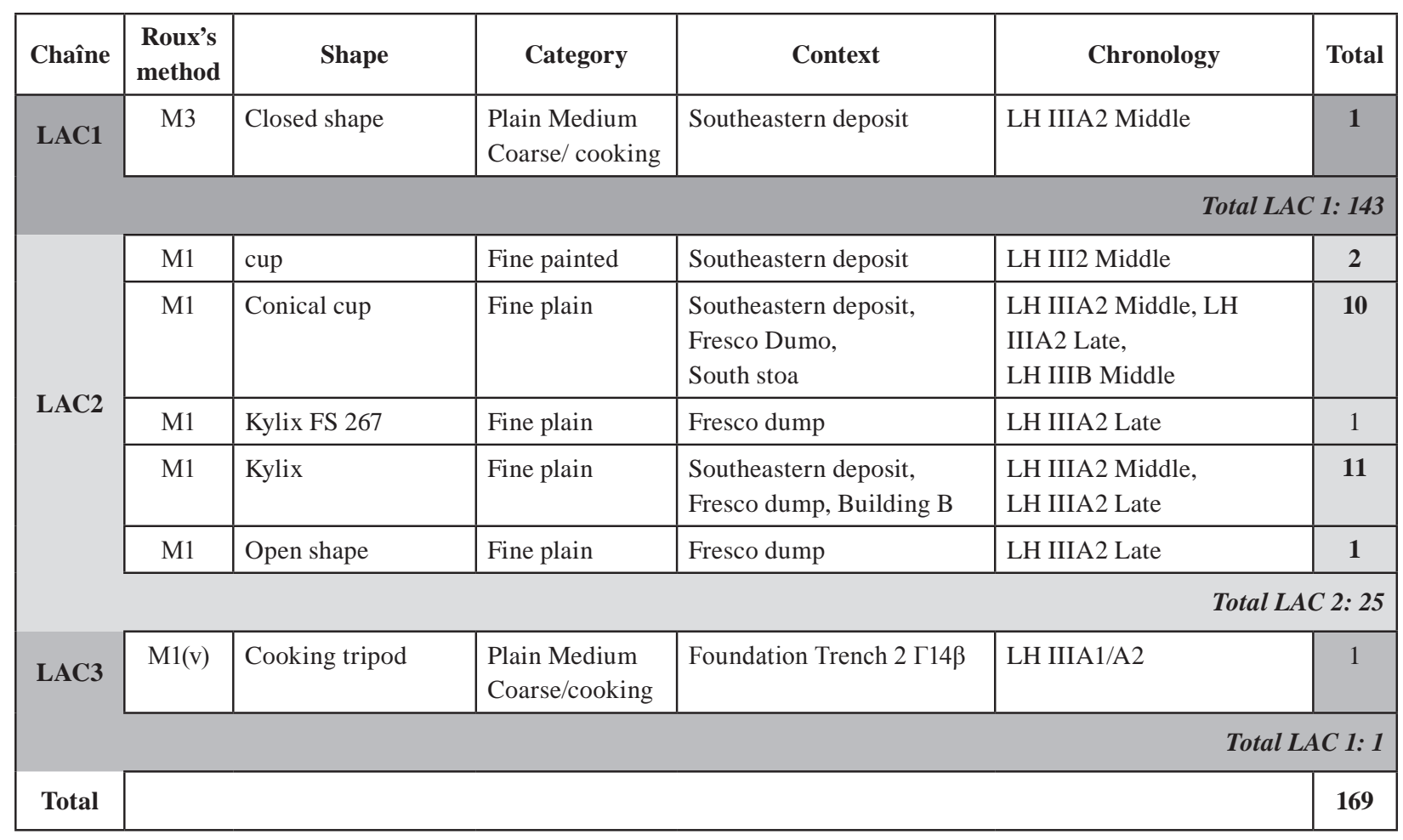

and thinning the walls and shows that the later introduction of RKE into the process has not influenced the microstructure of coils. In some pots, we can discern small zones with diagonally oriented voids that indicate the effect of RKE on particular vessel's parts, like rims, where the wheel was probably used more intensively. Otherwise, the overall microstructure suggests coil-built roughouts that preserve most of the characteristics of coiling and indicate the use of the wheel only during the final operations as a secondary forming technique ${ }^{137}$.

\subsubsection{Identification of chaînes opératoires}

Regarding the use of wheel-coiling techniques at Ayios Vasileios, the combination of the macroscopic and X-Ray data along with the typological and stylistic features of the examined assemblage has allowed the classification of wheelmade pottery according to chaînes opératoires (Tabs. 6-7). Two main chaînes opératoires have been identified, each one based on a specific wheel-coiling method (Tabs. 8-9).

137 Of the two X-Ray samples showing the wheel-coiling method 1, the first belongs to a large coarse vessel (sample XRay 18; Fig. 26) and the other to a small plain conical cup of medium fine fabric (sample XRay 8; Figs. 11 and (a) Chaîne opératoire LAC 1 (Fig. 14): This popular chaîne opératoire is based on the wheelcoiling method 3 and occurs in a great variety of fine vessels including small and mediumsized open and closed shapes belonging to plain, monochrome and painted wares: conical cups and other types of cups, kylikes, goblets, kraters, bowls including the angular type, as wells as miscellaneous vessel shapes such as a rhyton and an alabastron (see Tab. 10). It is also identified in some coarser vessels like cooking pots. These vessels are made by coils formed by discontinuous pressures (Fig. 15c-d), whereas the wheel with fluctuating speeds is used from an early stage of joining the coils, thinning the walls, and shaping the roughout. These operations mediated by RKE and involving continuous pressures on the clay walls account for the strongly deformed coil-built roughouts (Fig. 15a-b). Regarding the particular potting practices involved in this chaîne, it is interesting to note that the way of forming the bases varies among the pots, especially bowls and cups. Most of the bases are made by

21). Two further X-Ray samples exhibiting wheel-coiling method 1 belong to non-local fabrics and will be published elsewhere (see above n. 131). 
Table 7 Catalogue of the samples examined through macroscopic and X-ray analysis at Ayios Vasileios. From the sherds studied only macroscopically, the table contains only the samples that are illustrated in the present study. For description of contexts see KARDAMAKi 2017.

\begin{tabular}{|c|c|c|c|c|c|c|c|c|c|c|}
\hline $\begin{array}{c}\text { Sample } \\
\text { no. }\end{array}$ & $\begin{array}{c}\text { XRay } \\
\text { sample }\end{array}$ & $\begin{array}{l}\text { Roux's } \\
\text { method }\end{array}$ & Chaîne & Shape & $\begin{array}{l}\text { Cate- } \\
\text { gory }\end{array}$ & $\begin{array}{l}\text { Fabric } \\
\text { code }\end{array}$ & Context & $\begin{array}{c}\text { Chrono- } \\
\log y\end{array}$ & Figure & $\begin{array}{c}\text { Publication } \\
\text { reference }\end{array}$ \\
\hline 01AV & & M3 & LAC1 & $\begin{array}{l}\text { Con. cup } \\
\text { FS } 204\end{array}$ & $\begin{array}{l}\text { Fine } \\
\text { plain }\end{array}$ & $\begin{array}{l}4 \mathrm{~b} / \mathrm{c} \\
\text { medium } \\
\text { fine }\end{array}$ & $\begin{array}{l}\text { Southeastern deposit } \\
\text { (context nr. 768) }\end{array}$ & \begin{tabular}{|l|} 
LH IIIA2 \\
Middle
\end{tabular} & $1 \mathrm{~b}$ & \\
\hline 02AV & & М3 & LAC1 & $\begin{array}{l}\text { Con. cup } \\
\text { FS } 204\end{array}$ & $\begin{array}{l}\text { Fine } \\
\text { plain }\end{array}$ & $4 c$ & Southeastern deposit & $\begin{array}{l}\text { LH IIIA2 } \\
\text { Middle }\end{array}$ & 2c, $18 \mathrm{~d}$ & $\begin{array}{l}\text { KARDAMAKI } \\
2017, \\
\text { Fig. } 20.306\end{array}$ \\
\hline 03AV & & М3 & LAC1 & \begin{tabular}{|l} 
Kylix \\
FS 264?
\end{tabular} & $\begin{array}{l}\text { Fine } \\
\text { plain }\end{array}$ & $4 c$ & $\begin{array}{l}\text { Southeastern deposit } \\
\text { (context nr. 768) }\end{array}$ & $\begin{array}{l}\text { LH IIIA2 } \\
\text { Middle }\end{array}$ & $1 \mathrm{c}$ & \\
\hline 06AV & & M3 & LAC1 & $\begin{array}{l}\text { Con. cup } \\
\text { FS } 204\end{array}$ & $\begin{array}{l}\text { Fine } \\
\text { plain }\end{array}$ & $4 \mathrm{~b} / \mathrm{c}$ & Southeastern deposit & $\begin{array}{l}\text { LH IIIA2 } \\
\text { Middle }\end{array}$ & 16a & \\
\hline 07AV & & М3 & LAC1 & Kylix & $\begin{array}{l}\text { Fine } \\
\text { plain }\end{array}$ & $4 \mathrm{~b} / \mathrm{c}$ & $\begin{array}{l}\text { Southeastern deposit } \\
\text { (context nr. 779) }\end{array}$ & $\begin{array}{l}\text { LH IIIA2 } \\
\text { Middle }\end{array}$ & 2a, 5d & \\
\hline $10 \mathrm{AV}$ & & M3 & LAC1 & $\begin{array}{l}\text { Open } \\
\text { shape }\end{array}$ & \begin{tabular}{|l} 
Fine \\
plain
\end{tabular} & $4 c$ & $\begin{array}{l}\text { Southeastern deposit } \\
\text { (context nr. 779) }\end{array}$ & $\begin{array}{l}\text { LH IIIA2 } \\
\text { Middle }\end{array}$ & $6 c$ & \\
\hline $12 \mathrm{AV}$ & & М3 & LAC1 & $\begin{array}{l}\text { Con. cup } \\
\text { FS } 204\end{array}$ & $\begin{array}{l}\text { Fine } \\
\text { plain }\end{array}$ & $4 \mathrm{~b} / \mathrm{c}$ & $\begin{array}{l}\text { Southeastern deposit } \\
\text { (context nr. 779) }\end{array}$ & $\begin{array}{l}\text { LH IIIA2 } \\
\text { Middle }\end{array}$ & $15 b$ & \\
\hline $13 A V$ & & М3 & LAC1 & $\begin{array}{l}\text { Open } \\
\text { shape }\end{array}$ & $\begin{array}{l}\text { Fine } \\
\text { plain }\end{array}$ & $4 \mathrm{~b} / \mathrm{c}$ & $\begin{array}{l}\text { Southeastern deposit } \\
\text { (context nr. 779) }\end{array}$ & $\begin{array}{l}\text { LH IIIA2 } \\
\text { Middle }\end{array}$ & $4 \mathrm{c}$ & \\
\hline 19AV & & M3 & LAC1 & Kylix & \begin{tabular}{|l} 
Fine \\
plain
\end{tabular} & $4 \mathrm{~b} / \mathrm{c}$ & $\begin{array}{l}\text { Southeastern deposit } \\
\text { (context nr. 779) }\end{array}$ & $\begin{array}{l}\text { LH IIIA2 } \\
\text { Middle }\end{array}$ & $17 \mathrm{~d}$ & \\
\hline $25 \mathrm{AV}$ & & М3 & LAC1 & Kylix & $\begin{array}{l}\text { Fine } \\
\text { plain }\end{array}$ & $4 \mathrm{~b} / \mathrm{c}$ & Southeastern deposit & $\begin{array}{l}\text { LH IIIA2 } \\
\text { Middle }\end{array}$ & $17 a$ & \\
\hline $31 \mathrm{AV}$ & & M1 & LAC2 & Kylix & \begin{tabular}{|l} 
Fine \\
plain
\end{tabular} & $4 \mathrm{~b} / \mathrm{c}$ & $\begin{array}{l}\text { Southeastern deposit } \\
\text { (context nr. 779) }\end{array}$ & $\begin{array}{l}\text { LH IIIA2 } \\
\text { Middle }\end{array}$ & $25 c$ & \\
\hline $35 \mathrm{AV}$ & & M3 & LAC1 & Kylix & $\begin{array}{l}\text { Fine } \\
\text { plain }\end{array}$ & 4 gray & $\begin{array}{l}\text { Southeastern deposit } \\
\text { (context nr. 779) }\end{array}$ & $\begin{array}{l}\text { LH IIIA2 } \\
\text { Middle }\end{array}$ & $20 \mathrm{~b}$ & \\
\hline $38 \mathrm{AV}$ & & M1 & LAC2 & kylix & \begin{tabular}{|l} 
Fine \\
plain
\end{tabular} & $4 \mathrm{~b} / \mathrm{c}$ & Southeastern deposit & $\begin{array}{l}\text { LH IIIA2 } \\
\text { Middle }\end{array}$ & $17 \mathrm{c}$ & \\
\hline 43AV & & М3 & LAC1 & Kylix & \begin{tabular}{|l} 
Fine \\
plain
\end{tabular} & $4 \mathrm{~b} / \mathrm{c}$ & $\begin{array}{l}\text { Southeastern deposit } \\
\text { (context nr. 779) }\end{array}$ & $\begin{array}{l}\text { LH IIIA2 } \\
\text { Middle }\end{array}$ & $2 \mathrm{~b}$ & \\
\hline $48 \mathrm{AV}$ & & М3 & LAC1 & $\begin{array}{l}\text { Open } \\
\text { shape }\end{array}$ & $\begin{array}{l}\text { Fine } \\
\text { painted }\end{array}$ & & $\begin{array}{l}\text { Southeastern deposit } \\
\text { (context nr. 765) }\end{array}$ & $\begin{array}{l}\text { LH IIIA2 } \\
\text { Middle }\end{array}$ & $5 b$ & \\
\hline $55 \mathrm{AV}$ & & М3 & LAC1 & $\begin{array}{l}\text { Conical } \\
\text { Rhyton } \\
\text { FS } 199\end{array}$ & $\begin{array}{l}\text { Fine } \\
\text { painted }\end{array}$ & $\begin{array}{l}\text { 3f light } \\
\text { red }\end{array}$ & Southeastern deposit & \begin{tabular}{|l} 
LH IIIA2 \\
Middle
\end{tabular} & $3 b, 6 b$ & $\begin{array}{l}\text { KARDAMAKI } \\
\text { 2017, } \\
\text { Fig. } 17.281\end{array}$ \\
\hline 59AV & & M3 & LAC1 & Goblet & $\begin{array}{l}\text { Fine } \\
\text { painted }\end{array}$ & $3 \mathrm{f}$ & Southeastern deposit & $\begin{array}{l}\text { LH IIIA2 } \\
\text { Middle }\end{array}$ & $17 \mathrm{f}$ & \\
\hline
\end{tabular}




\begin{tabular}{|c|c|c|c|c|c|c|c|c|c|c|}
\hline $\begin{array}{c}\text { Sample } \\
\text { no. }\end{array}$ & $\begin{array}{c}\text { XRay } \\
\text { sample }\end{array}$ & $\begin{array}{l}\text { Roux's } \\
\text { method }\end{array}$ & Chaîne & Shape & $\begin{array}{l}\text { Cate- } \\
\text { gory }\end{array}$ & $\begin{array}{c}\text { Fabric } \\
\text { code }\end{array}$ & Context & $\begin{array}{c}\text { Chrono- } \\
\operatorname{logy}\end{array}$ & Figure & $\begin{array}{c}\text { Publication } \\
\text { reference }\end{array}$ \\
\hline 61AV & & M1 & LAC2 & $\begin{array}{l}\text { Kylix/ } \\
\text { kantharos }\end{array}$ & $\begin{array}{l}\text { Fine } \\
\text { plain }\end{array}$ & $4 \mathrm{~b} / \mathrm{c}$ & Southeastern deposit & $\begin{array}{l}\text { LH IIIA2 } \\
\text { Middle }\end{array}$ & $22 \mathrm{a}$ & $\begin{array}{l}\text { KARDAMAKI } \\
\text { 2017, } \\
\text { Fig. } 18.297\end{array}$ \\
\hline 62AV & & M3 & LAC1 & $\begin{array}{l}\text { Miniature } \\
\text { cup }\end{array}$ & $\begin{array}{l}\text { Fine } \\
\text { painted }\end{array}$ & $\begin{array}{l}\text { 3f light } \\
\text { red }\end{array}$ & Southeastern deposit & $\begin{array}{l}\text { LH IIIA2 } \\
\text { Middle }\end{array}$ & 1a & $\begin{array}{l}\text { KARDAMAKI } \\
\text { 2017, } \\
\text { Fig. } 17.278\end{array}$ \\
\hline 68AV & & M2 & LAC2 & Kylix & $\begin{array}{l}\text { Fine } \\
\text { plain }\end{array}$ & $4 \mathrm{~b} / \mathrm{c}$ & $\begin{array}{l}\text { Southeastern deposit } \\
\text { (context nr. 776) }\end{array}$ & $\begin{array}{l}\text { LH IIIA2 } \\
\text { Middle }\end{array}$ & $22 b$ & \\
\hline 71AV & & M3 & LAC1 & Kylix & $\begin{array}{l}\text { Fine } \\
\text { plain }\end{array}$ & $4 \mathrm{~b} / \mathrm{c}$ & $\begin{array}{l}\text { Southeastern deposit } \\
\text { (context nr. 779) }\end{array}$ & $\begin{array}{l}\text { LH IIIA2 } \\
\text { Middle }\end{array}$ & $1 e, 5 e$ & \\
\hline 76AV & & M3 & LAC1 & Kylix & $\begin{array}{l}\text { Fine } \\
\text { plain }\end{array}$ & $4 \mathrm{c}$ & $\begin{array}{l}\text { Southeastern deposit } \\
\text { (context nr. 779) }\end{array}$ & $\begin{array}{l}\text { LH IIIA2 } \\
\text { Middle }\end{array}$ & $20 c$ & \\
\hline 79AV & & M1 & LAC2 & $\begin{array}{l}\text { Cup } \\
\text { FS219 }\end{array}$ & \begin{tabular}{|l} 
Fine \\
painted
\end{tabular} & $3 g$ & Southeastern deposit & $\begin{array}{l}\text { LH IIIA2 } \\
\text { Middle }\end{array}$ & 23a & $\begin{array}{l}\text { KARDAMAKI } \\
\text { 2017, } \\
\text { Fig. } 17.277\end{array}$ \\
\hline 81AV & & M3 & LAC1 & $\begin{array}{l}\text { Con. cup } \\
\text { FS } 204\end{array}$ & $\begin{array}{l}\text { Fine } \\
\text { plain }\end{array}$ & $4 \mathrm{~b} / \mathrm{c}$ & Southeastern deposit & $\begin{array}{l}\text { LH IIIA2 } \\
\text { Middle }\end{array}$ & $16 \mathrm{c}$ & $\begin{array}{l}\text { KARDAMAKI } \\
\text { 2017, } \\
\text { Fig. } 20.311\end{array}$ \\
\hline 83AV & & M1 & LAC2 & $\begin{array}{l}\text { Con. cup } \\
\text { FS } 204\end{array}$ & $\begin{array}{l}\text { Fine } \\
\text { plain }\end{array}$ & $4 \mathrm{~b} / \mathrm{c}$ & $\begin{array}{l}\text { Southeastern deposit } \\
\text { (context nr. 769) }\end{array}$ & $\begin{array}{l}\text { LH IIIA2 } \\
\text { Middle }\end{array}$ & $23 b$ & \\
\hline 87AV & & M1 & LAC2 & $\begin{array}{l}\text { Con. cup } \\
\text { FS } 204\end{array}$ & $\begin{array}{l}\text { Fine } \\
\text { plain }\end{array}$ & $4 \mathrm{~b} / \mathrm{c}$ & $\begin{array}{l}\text { Southeastern deposit } \\
\text { (context nr. 773) }\end{array}$ & $\begin{array}{l}\text { LH IIIA2 } \\
\text { Middle }\end{array}$ & $4 a, 5 g$ & \\
\hline 89AV & & M1 & LAC2 & Kylix & $\begin{array}{l}\text { Fine } \\
\text { plain }\end{array}$ & $4 \mathrm{c}$ & $\begin{array}{l}\text { Southeastern deposit } \\
\text { (context nr. 773) }\end{array}$ & $\begin{array}{l}\text { LH IIIA2 } \\
\text { Middle }\end{array}$ & $24 a$ & \\
\hline 96AV & & M3 & LAC1 & $\begin{array}{l}\text { Closed } \\
\text { shape }\end{array}$ & $\begin{array}{l}\text { Medium } \\
\text { coarse }\end{array}$ & $\begin{array}{l}5 \text { Mica- } \\
\text { ceous }\end{array}$ & Southeastern deposit & $\begin{array}{l}\text { LH IIIA2 } \\
\text { Middle }\end{array}$ & 1f & \\
\hline 102AV & & M1 & LAC2 & $\begin{array}{l}\text { Con. cup } \\
\text { FS } 204\end{array}$ & $\begin{array}{l}\text { Fine } \\
\text { plain }\end{array}$ & $4 \mathrm{~b} / \mathrm{c}$ & $\begin{array}{l}\text { Southeastern deposit } \\
\text { (context nr. 763) }\end{array}$ & $\begin{array}{l}\text { LH IIIA2 } \\
\text { Middle }\end{array}$ & $24 \mathrm{~b}$ & \\
\hline 105AV & & M3 & LAC1 & $\begin{array}{l}\text { Open } \\
\text { shape }\end{array}$ & $\begin{array}{l}\text { Fine } \\
\text { plain }\end{array}$ & & $\begin{array}{l}\text { Southeastern deposit } \\
\text { (context nr. 777) }\end{array}$ & $\begin{array}{l}\text { LH IIIA2 } \\
\text { Middle }\end{array}$ & $5 c$ & \\
\hline 107AV & & М3 & LAC1 & $\begin{array}{l}\text { Carinated } \\
\text { kylix } \\
\text { FS } 267\end{array}$ & $\begin{array}{l}\text { Fine } \\
\text { plain }\end{array}$ & $4 \mathrm{~b} / \mathrm{c}$ & Southeastern deposit & $\begin{array}{l}\text { LH IIIA2 } \\
\text { Middle }\end{array}$ & $20 \mathrm{a}$ & $\begin{array}{l}\text { KARDAMAKI } \\
\text { 2017, } \\
\text { Fig. } 18.291\end{array}$ \\
\hline 109AV & & M1 & LAC2 & Kylix & $\begin{array}{l}\text { Fine } \\
\text { plain }\end{array}$ & $4 \mathrm{~b} / \mathrm{c}$ & $\begin{array}{l}\text { Southeastern deposit } \\
\text { (context nr. 773) }\end{array}$ & $\begin{array}{l}\text { LH IIIA2 } \\
\text { Middle }\end{array}$ & $22 d$ & \\
\hline 121AV & & M3 & LAC1 & Kylix & $\begin{array}{l}\text { Fine } \\
\text { plain }\end{array}$ & $4 \mathrm{~b} / \mathrm{c}$ & Building B/Room 6 & $\begin{array}{l}\text { LH IIIA2 } \\
\text { Late }\end{array}$ & $17 e$ & $\begin{array}{l}\text { KARDAMAKI } \\
2017, \\
\text { Fig. } 10.176\end{array}$ \\
\hline 132AV & & M3 & LAC1 & Kylix & $\begin{array}{l}\text { Fine } \\
\text { plain }\end{array}$ & $4 \mathrm{~b} / \mathrm{c}$ & $\begin{array}{l}\text { Fresco Dump } \\
\text { (context nr. 122a) }\end{array}$ & $\begin{array}{l}\text { LH IIIA2 } \\
\text { Late }\end{array}$ & $\begin{array}{l}17 \mathrm{i} \\
20 \mathrm{~d}\end{array}$ & \\
\hline
\end{tabular}




\begin{tabular}{|c|c|c|c|c|c|c|c|c|c|c|}
\hline $\begin{array}{c}\text { Sample } \\
\text { no. }\end{array}$ & $\begin{array}{c}\text { XRay } \\
\text { sample }\end{array}$ & $\begin{array}{l}\text { Roux's } \\
\text { method }\end{array}$ & Chaîne & Shape & $\begin{array}{l}\text { Cate- } \\
\text { gory }\end{array}$ & $\begin{array}{l}\text { Fabric } \\
\text { code }\end{array}$ & Context & $\begin{array}{c}\text { Chrono- } \\
\text { logy }\end{array}$ & Figure & $\begin{array}{c}\text { Publication } \\
\text { reference }\end{array}$ \\
\hline 139AV & & М3 & LAC1 & $\begin{array}{l}\text { Con. cup } \\
\text { FS } 204\end{array}$ & $\begin{array}{l}\text { Fine } \\
\text { plain }\end{array}$ & $4 \mathrm{~b} / \mathrm{c}$ & Fresco Dump & $\begin{array}{l}\text { LH IIIA2 } \\
\text { Late }\end{array}$ & $4 \mathrm{~b}$ & $\begin{array}{l}\text { KARDAMAKI } \\
2017, \\
\text { Fig. } 14.221\end{array}$ \\
\hline 148AV & & M3 & LAC1 & Crater & $\begin{array}{l}\text { Fine } \\
\text { plain }\end{array}$ & $4 \mathrm{~b} / \mathrm{c}$ & Fresco Dump & $\begin{array}{l}\text { LH IIIA2 } \\
\text { Late }\end{array}$ & $6 a$ & $\begin{array}{l}\text { KARDAMAKI } \\
2017, \\
\text { Fig. } 14.222\end{array}$ \\
\hline 156AV & & M1 & LAC2 & Kylix & $\begin{array}{l}\text { Fine } \\
\text { plain }\end{array}$ & 4 green & Fresco Dump & $\begin{array}{l}\text { LH IIIA2 } \\
\text { Late }\end{array}$ & $\begin{array}{l}5 h, \\
25 a-b\end{array}$ & $\begin{array}{l}\text { KARDAMAKI } \\
2017, \\
\text { Fig. } 13.211\end{array}$ \\
\hline 157AV & & M3 & LAC1 & $\begin{array}{l}\text { Carinated } \\
\text { kylix } \\
\text { FS } 267\end{array}$ & $\begin{array}{l}\text { Fine } \\
\text { plain }\end{array}$ & 4 green & Building B/Room 6 & $\begin{array}{l}\text { LH IIIA2 } \\
\text { Late }\end{array}$ & $\begin{array}{l}7 \mathrm{a}, \\
41.2\end{array}$ & $\begin{array}{l}\text { KARDAMAKI } \\
2017, \\
\text { Fig. } 10.174\end{array}$ \\
\hline 172AV & & M1 & LAC2 & $\begin{array}{l}\text { Open } \\
\text { shape }\end{array}$ & $\begin{array}{l}\text { Fine } \\
\text { plain }\end{array}$ & $4 \mathrm{~b} / \mathrm{c}$ & $\begin{array}{l}\text { Fresco Dump } \\
\text { (context nr. 166III) }\end{array}$ & $\begin{array}{l}\text { LH IIIA2 } \\
\text { Late }\end{array}$ & 22c & \\
\hline 174AV & & M3 & LAC1 & $\begin{array}{l}\text { Closed } \\
\text { shape? }\end{array}$ & $\begin{array}{l}\text { Fine } \\
\text { plain }\end{array}$ & $\begin{array}{l}\text { Second. } \\
\text { burnt }\end{array}$ & $\begin{array}{l}\text { South Stoa } \\
\text { (context nr. 1054) }\end{array}$ & $\begin{array}{l}\text { LH IIIB } \\
\text { Middle }\end{array}$ & 8 & \\
\hline 175AV & & M1 & LAC2 & $\begin{array}{l}\text { Con. cup } \\
\text { FS } 204\end{array}$ & $\begin{array}{l}\text { Fine } \\
\text { plain }\end{array}$ & $\begin{array}{l}\text { 4b/c } \\
\text { light }\end{array}$ & $\begin{array}{l}\text { South Stoa } \\
\text { (context nr. 1054) }\end{array}$ & $\begin{array}{l}\text { LH IIIB } \\
\text { Middle }\end{array}$ & $\begin{array}{l}24 c \\
42.2\end{array}$ & \\
\hline 176AV & & М3 & LAC1 & $\begin{array}{l}\text { Carinated } \\
\text { kylix } \\
\text { FS } 267\end{array}$ & $\begin{array}{l}\text { Fine } \\
\text { plain }\end{array}$ & $\begin{array}{l}\text { Second. } \\
\text { burnt }\end{array}$ & $\begin{array}{l}\text { South Stoa } \\
\text { (context nr. 1054) }\end{array}$ & $\begin{array}{l}\text { LH IIIB } \\
\text { Middle }\end{array}$ & 17b, h & \\
\hline $180 \mathrm{AV}$ & & M3 & LAC1 & $\begin{array}{l}\text { Closed } \\
\text { shape }\end{array}$ & $\begin{array}{l}\text { Fine } \\
\text { painted }\end{array}$ & & $\begin{array}{l}\text { Construction Fill } \\
\text { Trench } 2 \\
\text { Square } \Gamma 14 \beta \\
\text { (context nr. 982) }\end{array}$ & $\begin{array}{l}\text { LH IIIA2 } \\
\text { Early }\end{array}$ & 3a & \\
\hline 181AV & & M3 & LAC1 & $\begin{array}{l}\text { Closed } \\
\text { shape }\end{array}$ & $\begin{array}{l}\text { Fine } \\
\text { painted }\end{array}$ & 3 gray & $\begin{array}{l}\text { Construction Fill } \\
\text { Trench } 2 \\
\text { Square } \Gamma 14 \beta \\
\text { (context nr. 982) }\end{array}$ & $\begin{array}{l}\text { LH IIIA2 } \\
\text { Early }\end{array}$ & $4 d$ & \\
\hline 185AV & & M3 & LAC1 & $\begin{array}{l}\text { Open } \\
\text { shape }\end{array}$ & $\begin{array}{l}\text { Fine } \\
\text { painted }\end{array}$ & 3 & Southeastern deposit & $\begin{array}{l}\text { LH IIIA2 } \\
\text { Middle }\end{array}$ & $15 \mathrm{e}$ & \\
\hline 189AV & & M3 & LAC1 & $\begin{array}{l}\text { Conical } \\
\text { cup }\end{array}$ & $\begin{array}{l}\text { Fine } \\
\text { plain }\end{array}$ & $\begin{array}{l}\text { 4b/c } \\
\text { medium } \\
\text { fine }\end{array}$ & $\begin{array}{l}\text { Construction Fill } \\
\text { Trench } 2 \\
\text { Square } \Gamma 14 \beta \\
\text { (context nr. 971) }\end{array}$ & $\begin{array}{l}\text { LH IIIA2 } \\
\text { Early }\end{array}$ & 18a & \\
\hline 194AV & & M3 & LAC1 & $\begin{array}{l}\text { Goblet } \\
\text { FS } 263\end{array}$ & $\begin{array}{l}\text { Fine } \\
\text { painted }\end{array}$ & $\begin{array}{l}3 f \text { light } \\
\text { red }\end{array}$ & \begin{tabular}{|l} 
Construction Fill \\
Trench 2 \\
Square $\Gamma 14 \beta$ \\
(context nr. 979)
\end{tabular} & $\begin{array}{l}\text { LH IIIA2 } \\
\text { Early }\end{array}$ & $1 \mathrm{~d}$ & \\
\hline 197AV & & M3 & LAC1 & $\begin{array}{l}\text { Kylix } \\
\text { FS } 266\end{array}$ & $\begin{array}{l}\text { Fine } \\
\text { plain }\end{array}$ & $4 \mathrm{~b} / \mathrm{c}$ & $\begin{array}{l}\text { Construction Fill } \\
\text { Trench } 2 \\
\text { Square } \Gamma 14 \beta \\
\text { (context nr. 975) }\end{array}$ & $\begin{array}{l}\text { LH IIIA2 } \\
\text { Early }\end{array}$ & $\begin{array}{l}17 g \\
41.1\end{array}$ & \\
\hline
\end{tabular}




\begin{tabular}{|c|c|c|c|c|c|c|c|c|c|c|}
\hline $\begin{array}{c}\text { Sample } \\
\text { no. }\end{array}$ & $\begin{array}{c}\text { XRay } \\
\text { sample }\end{array}$ & $\begin{array}{l}\text { Roux's } \\
\text { method }\end{array}$ & Chaîne & Shape & $\begin{array}{l}\text { Cate- } \\
\text { gory }\end{array}$ & $\begin{array}{l}\text { Fabric } \\
\text { code }\end{array}$ & Context & $\begin{array}{c}\text { Chrono- } \\
\operatorname{logy}\end{array}$ & Figure & $\begin{array}{c}\text { Publication } \\
\text { reference }\end{array}$ \\
\hline 198AV & & M3 & LAC1 & $\begin{array}{l}\text { Con. cup } \\
\text { FS } 204\end{array}$ & $\begin{array}{l}\text { Fine } \\
\text { plain }\end{array}$ & $4 \mathrm{~b} / \mathrm{c}$ & $\begin{array}{l}\text { Construction Fill } \\
\text { Trench } 2 \\
\text { Square } \Gamma 14 \beta \\
\text { (context nr. 975) }\end{array}$ & $\begin{array}{l}\text { LH IIIA2 } \\
\text { Early }\end{array}$ & $5 f, 16 b$ & \\
\hline 202AV & & M3 & LAC1 & \begin{tabular}{|l} 
Deep \\
bowl \\
FS 284
\end{tabular} & $\begin{array}{l}\text { Fine } \\
\text { painted }\end{array}$ & $\begin{array}{l}\text { 3f light } \\
\text { red }\end{array}$ & Trench E13 $\delta$ & $\begin{array}{l}\text { LH IIIB2/ } \\
\text { IIIC Early }\end{array}$ & $\begin{array}{l}5 a, \\
40.5\end{array}$ & $\begin{array}{l}\text { KARDAMAKI } \\
\text { - VASILO- } \\
\text { GAMVROU } \\
\text { forthcoming }\end{array}$ \\
\hline 261AV & $\begin{array}{c}\text { XRay } \\
\text { sample } \\
2\end{array}$ & M3 & LAC1 & Crater & $\begin{array}{l}\text { Fine } \\
\text { plain }\end{array}$ & $\begin{array}{l}\text { 4b/c } \\
\text { light, } \\
4 \text { gray }\end{array}$ & Southeastern deposit & $\begin{array}{l}\text { LH IIIA2 } \\
\text { Middle }\end{array}$ & $\begin{array}{l}12 \mathrm{~b} \\
41.3\end{array}$ & $\begin{array}{l}\text { KARDAMAKI } \\
\text { 2017, } \\
\text { Fig. } 19.302\end{array}$ \\
\hline 262AV & $\begin{array}{c}\text { XRay } \\
\text { sample } \\
3\end{array}$ & M3 & LAC1 & Crater & $\begin{array}{l}\text { Fine } \\
\text { plain }\end{array}$ & $4 \mathrm{c}$ & Southeastern deposit & $\begin{array}{l}\text { LH IIIA2 } \\
\text { Middle }\end{array}$ & & $\begin{array}{l}\text { KARDAMAKI } \\
2017, \\
\text { Fig. } 19.300\end{array}$ \\
\hline 263AV & $\begin{array}{c}\text { XRay } \\
\text { sample } \\
4\end{array}$ & M3 & LAC1 & $\begin{array}{l}\text { Globular } \\
\text { kylix } \\
\text { FS } 264\end{array}$ & $\begin{array}{l}\text { Fine } \\
\text { plain }\end{array}$ & $\begin{array}{l}\text { 4c, } \\
4 \text { gray }\end{array}$ & $\begin{array}{l}\text { South stoa, destruc- } \\
\text { tion deposit }\end{array}$ & $\begin{array}{l}\text { LH IIIB } \\
\text { Middle }\end{array}$ & & $\begin{array}{l}\text { KARDAMAKI } \\
\text { 2017, } \\
\text { Fig. } 20.318\end{array}$ \\
\hline 264AV & $\begin{array}{c}\text { XRay } \\
\text { sample } \\
5\end{array}$ & M3 & LAC1 & $\begin{array}{l}\text { Con. cup } \\
\text { FS } 204\end{array}$ & $\begin{array}{l}\text { Fine } \\
\text { plain }\end{array}$ & $\begin{array}{l}\text { 4b/c } \\
\text { medium } \\
\text { fine }\end{array}$ & $\begin{array}{l}\text { Southeastern deposit } \\
\text { (context nr. 779) }\end{array}$ & $\begin{array}{l}\text { LH IIIA2 } \\
\text { Middle }\end{array}$ & $\begin{array}{l}13, \\
41.5\end{array}$ & \\
\hline 265AV & $\begin{array}{c}\text { XRay } \\
\text { sample } \\
6\end{array}$ & M3 & LAC1 & $\begin{array}{l}\text { Alabas- } \\
\text { tron }\end{array}$ & $\begin{array}{l}\text { Fine } \\
\text { painted }\end{array}$ & $\begin{array}{l}\text { 3f light } \\
\text { red }\end{array}$ & Southeastern deposit & $\begin{array}{l}\text { LH IIIA2 } \\
\text { Middle }\end{array}$ & $\begin{array}{l}15 d, \\
40.4\end{array}$ & $\begin{array}{l}\text { KARDAMAKI } \\
\text { 2017, } \\
\text { Fig. } 17.283\end{array}$ \\
\hline 266AV & $\begin{array}{c}\text { XRay } \\
\text { sample } \\
7\end{array}$ & M3 & LAC1 & Crater & $\begin{array}{l}\text { Fine } \\
\text { plain }\end{array}$ & 4c & Southeastern deposit & $\begin{array}{l}\text { LH IIIA2 } \\
\text { Middle }\end{array}$ & 19a & $\begin{array}{l}\text { KARDAMAKI } \\
2017, \\
\text { Fig. } 19.301\end{array}$ \\
\hline 267AV & $\begin{array}{c}\text { XRay } \\
\text { sample } \\
8\end{array}$ & M1 & LAC2 & $\begin{array}{l}\text { Con. cup } \\
\text { FS } 204\end{array}$ & $\begin{array}{l}\text { Fine } \\
\text { plain }\end{array}$ & $\begin{array}{l}\text { 4b/c } \\
\text { medium } \\
\text { fine }\end{array}$ & Southeastern deposit & $\begin{array}{l}\text { LH IIIA2 } \\
\text { Middle }\end{array}$ & $\begin{array}{l}11,21, \\
42.1\end{array}$ & $\begin{array}{l}\text { KARDAMAKI } \\
\text { 2017, } \\
\text { Fig. } 20.312\end{array}$ \\
\hline 268AV & $\begin{array}{c}\text { XRay } \\
\text { sample } \\
9\end{array}$ & M3 & LAC1 & $\begin{array}{l}\text { Angular } \\
\text { bowl } \\
\text { Large FS } \\
295\end{array}$ & $\begin{array}{l}\text { Fine } \\
\text { Plain } \\
\text { (over- } \\
\text { fired?) }\end{array}$ & 4 gray & Southeastern deposit & $\begin{array}{l}\text { LH IIIA2 } \\
\text { Middle }\end{array}$ & $\begin{array}{l}2 \mathrm{~d}, 14, \\
15 \mathrm{a}, \\
16 \mathrm{~d}, \\
41.4\end{array}$ & $\begin{array}{l}\text { KARDAMAKI } \\
\text { 2017, } \\
\text { Fig. } 20.303\end{array}$ \\
\hline 269AV & $\begin{array}{c}\text { XRay } \\
\text { sample } \\
10\end{array}$ & M3 & LAC1 & \begin{tabular}{|l} 
Carin. \\
kylix \\
FS 267
\end{tabular} & $\begin{array}{l}\text { Fine } \\
\text { plain }\end{array}$ & 4 gray & Fresco dump & $\begin{array}{l}\text { LH IIIA2 } \\
\text { Late }\end{array}$ & 10 & $\begin{array}{l}\text { KARDAMAKI } \\
\text { 2017, } \\
\text { Fig. } 13.202\end{array}$ \\
\hline 270AV & $\begin{array}{c}\text { XRay } \\
\text { sample } \\
11\end{array}$ & M3 & LAC1 & $\begin{array}{l}\text { Goblet } \\
\text { FS } 263\end{array}$ & $\begin{array}{l}\text { Fine } \\
\text { painted }\end{array}$ & $\begin{array}{l}\text { 3f light } \\
\text { red (dust } \\
\text { size } \\
\text { silver } \\
\text { spark- } \\
\text { ling } \\
\text { incl.) }\end{array}$ & Southeastern deposit & $\begin{array}{l}\text { LH IIIA2 } \\
\text { Middle }\end{array}$ & $\begin{array}{l}18 c, \\
40.1\end{array}$ & $\begin{array}{l}\text { KARDAMAKI } \\
\text { 2017, } \\
\text { Fig. } 15.252\end{array}$ \\
\hline
\end{tabular}




\begin{tabular}{|c|c|c|c|c|c|c|c|c|c|c|}
\hline $\begin{array}{c}\text { Sample } \\
\text { no. }\end{array}$ & $\begin{array}{l}\text { XRay } \\
\text { sample }\end{array}$ & $\begin{array}{l}\text { Roux's } \\
\text { method }\end{array}$ & Chaîne & Shape & $\begin{array}{l}\text { Cate- } \\
\text { gory }\end{array}$ & $\begin{array}{l}\text { Fabric } \\
\text { code }\end{array}$ & Context & $\begin{array}{c}\text { Chrono- } \\
\log y\end{array}$ & Figure & $\begin{array}{c}\text { Publication } \\
\text { reference }\end{array}$ \\
\hline 272AV & $\begin{array}{c}\text { XRay } \\
\text { sample } \\
13\end{array}$ & M3 & LAC1 & $\begin{array}{l}\text { Rhyton } \\
\text { FS } 199\end{array}$ & $\begin{array}{l}\text { Fine } \\
\text { painted }\end{array}$ & $\begin{array}{l}\text { 3f light } \\
\text { red }\end{array}$ & Southeastern deposit & $\begin{array}{l}\text { LH IIIA2 } \\
\text { Middle }\end{array}$ & 40.3 & $\begin{array}{l}\text { KARDAMAKI } \\
2017, \\
\text { Fig. } 17.280\end{array}$ \\
\hline 273AV & $\begin{array}{c}\text { XRay } \\
\text { sample } \\
14\end{array}$ & M3 & LAC1 & $\begin{array}{l}\text { Cup } \\
\text { FS } 220\end{array}$ & $\begin{array}{l}\text { Fine } \\
\text { painted }\end{array}$ & $\begin{array}{l}\text { 3f light } \\
\text { brown }\end{array}$ & Southeastern deposit & $\begin{array}{l}\text { LH IIIA2 } \\
\text { Middle }\end{array}$ & $\begin{array}{l}12 \mathrm{a}, \\
18 \mathrm{~b}, \\
40.2\end{array}$ & $\begin{array}{l}\text { KARDAMAKI } \\
2017, \\
\text { Fig. } 17.274\end{array}$ \\
\hline 274AV & $\begin{array}{c}\text { XRay } \\
\text { sample } \\
16\end{array}$ & M3 & LAC1 & $\begin{array}{l}\text { Angular } \\
\text { bowl } \\
\text { FS } 295\end{array}$ & $\begin{array}{l}\text { Fine } \\
\text { plain }\end{array}$ & $\begin{array}{l}\text { 4b/c } \\
\text { light }\end{array}$ & $\begin{array}{l}\text { South stoa, destruc- } \\
\text { tion deposit }\end{array}$ & $\begin{array}{l}\text { LH IIIB } \\
\text { Middle }\end{array}$ & $\begin{array}{l}7 \mathrm{~b}, 9 \\
19 \mathrm{~b}\end{array}$ & $\begin{array}{l}\text { KARDAMAKI } \\
2017, \\
\text { Fig. } 20.320\end{array}$ \\
\hline 276AV & $\begin{array}{c}\text { XRay } \\
\text { sample } \\
18\end{array}$ & M1(v) & LAC3 & $\begin{array}{l}\text { Cooking } \\
\text { tripod }\end{array}$ & $\begin{array}{l}\text { Medium } \\
\text { coarse } \\
\text { (Local?) }\end{array}$ & $\begin{array}{l}5 \text { Mica- } \\
\text { ceous }\end{array}$ & $\begin{array}{l}\text { Foundation Trench } 1 \\
\text { Square } \Gamma 14 \beta \\
\text { (context nr. 724) }\end{array}$ & $\begin{array}{l}\text { LH IIIA1/ } \\
\text { LH IIIA2 }\end{array}$ & $\begin{array}{l}26-27 \\
42.3\end{array}$ & \\
\hline 300AV & & M3 & LAC1 & Lamp & $\begin{array}{l}\text { Medium } \\
\text { coarse } \\
\text { (Local?) }\end{array}$ & $\begin{array}{l}5 \text { Mica- } \\
\text { ceous }\end{array}$ & Southeastern deposit & $\begin{array}{l}\text { LH IIIA2 } \\
\text { Middle }\end{array}$ & $15 c$ & \\
\hline
\end{tabular}

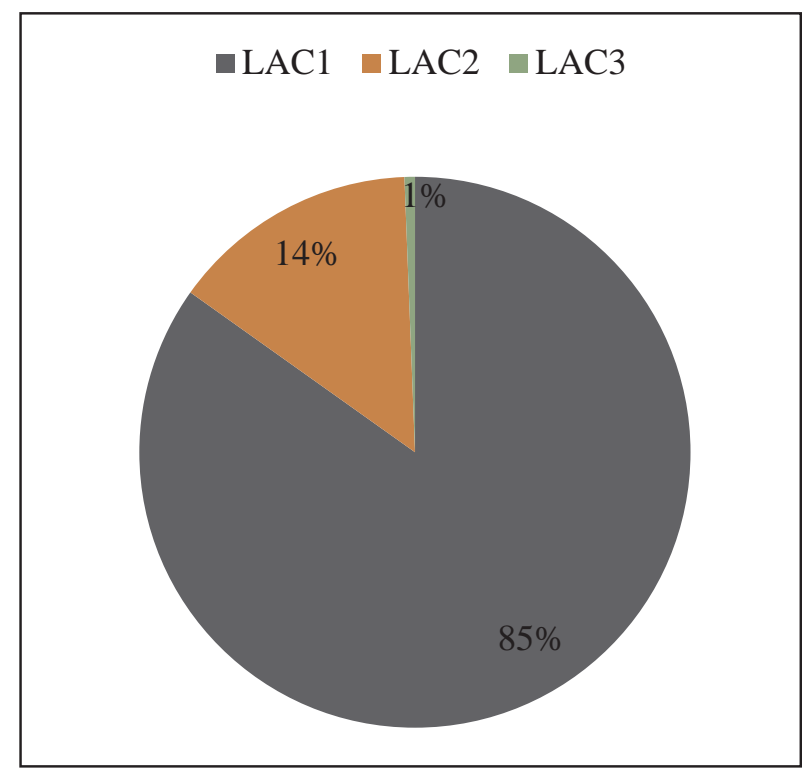

Table 8 Ayios Vasileios. Distribution of chaînes opératoires over the examined wheelmade assemblage

a coil deployed as a spiral (Fig. 16a-b) whereas a smaller part is characterized by bases made by one flattened slab or even more clay layers (flattened pieces of clay) (Fig. 16c-d), on

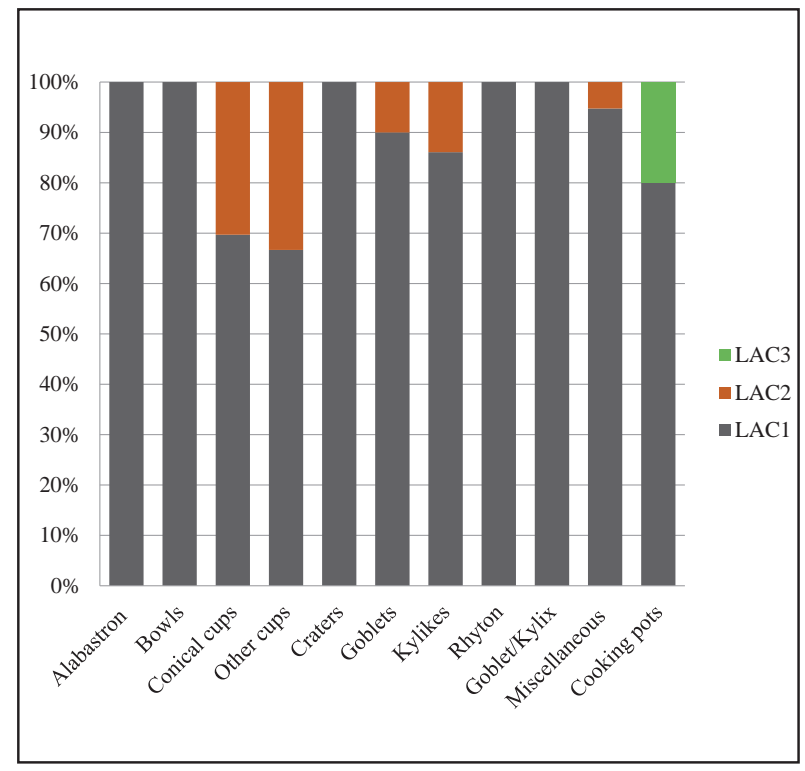

Table 9 Ayios Vasileios. Wheelmade shapes over identified chaînes opératoires

which the coils of the body are subsequently successively built one upon the other. ${ }^{138}$ Regarding such composite shapes as kylikes and goblets, it seems that the different parts are

138 For the slab-layer technique, see Kozatsas ET AL. 2018; For the combination of this technique with RKE see TODARO 2019. 
made separately, to be attached one after the other from the bottom to the top. On the one hand, the stem is added to a flattened disc made usually by coiling and sometimes by a slab, and both parts seem to be attached and shaped with the help of RKE (Fig. 17a-b). On the other hand, the coils are placed around the upper part of the stem (Fig. 17c-f) in order to

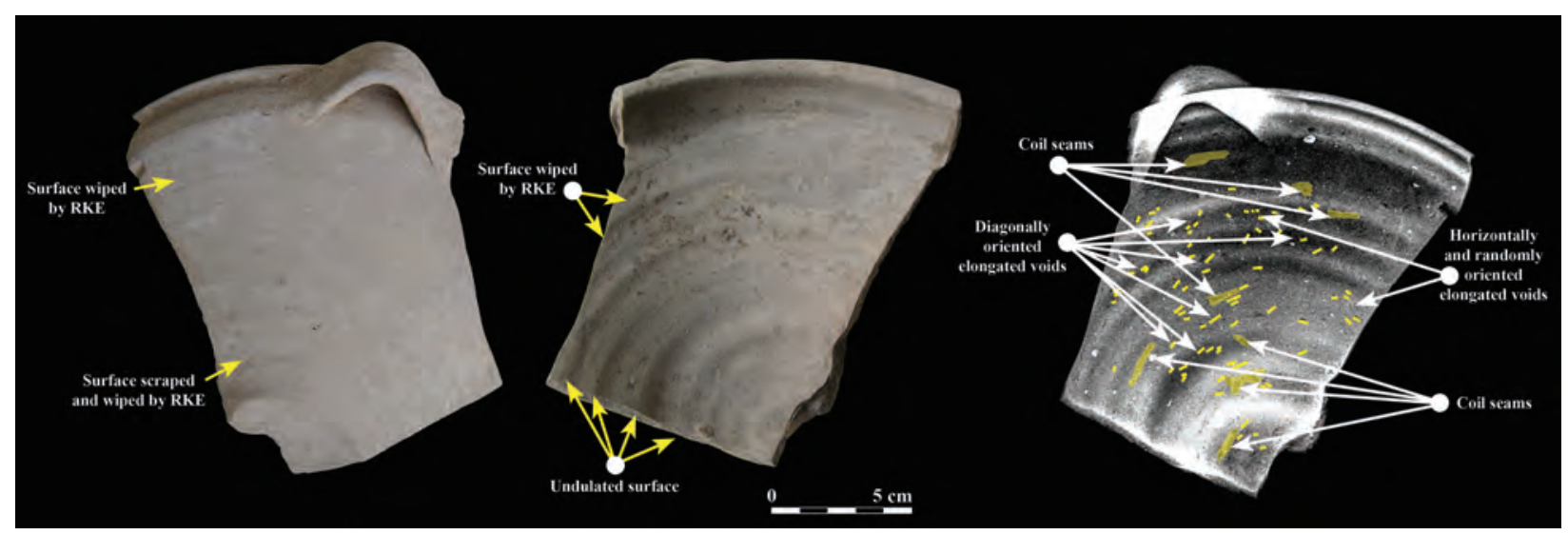

Fig. 14 Ayios Vasileios. Example of the chaîne opératoire LAC1 (268AV - XRay sample 9) (Photo by M. Choleva) (XRay by I. Basourakos, medical center Sparta)

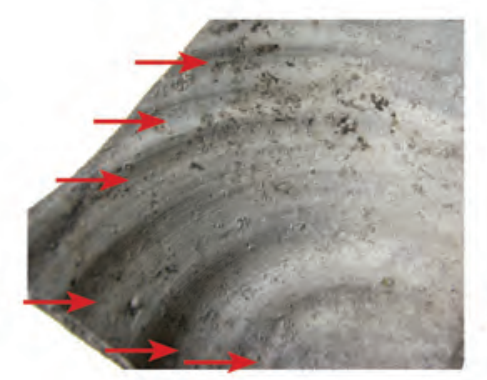

(a)

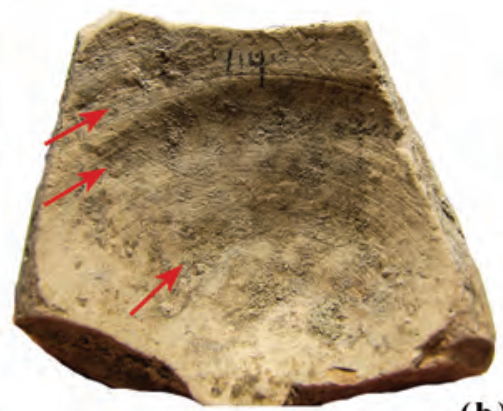

(b)

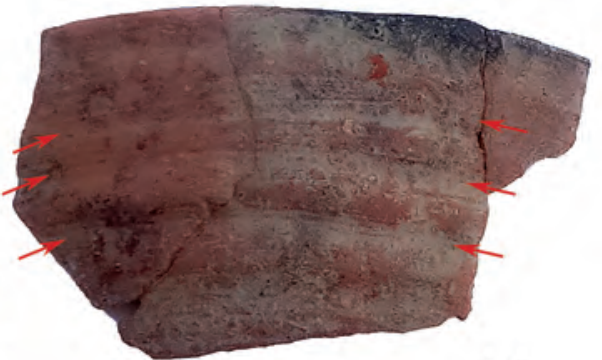

(c)
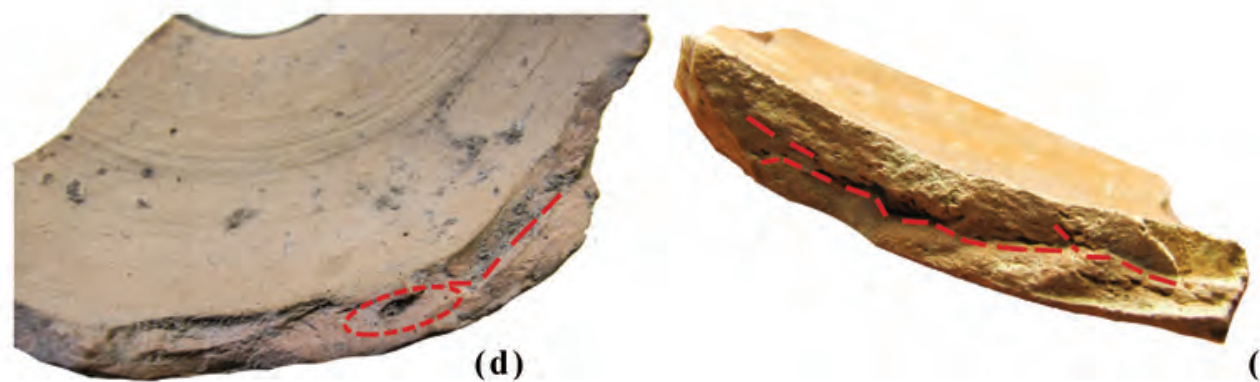

(e)

Fig. 15 Ayios Vasileios. Macro-features indicative of the wheel-coiling method 3: (a) 268AV (XRay sample 9); (b) 12AV; (c) 300AV; (d) 265AV (XRay sample 6); (e) 185AV (Photos by M. Choleva)
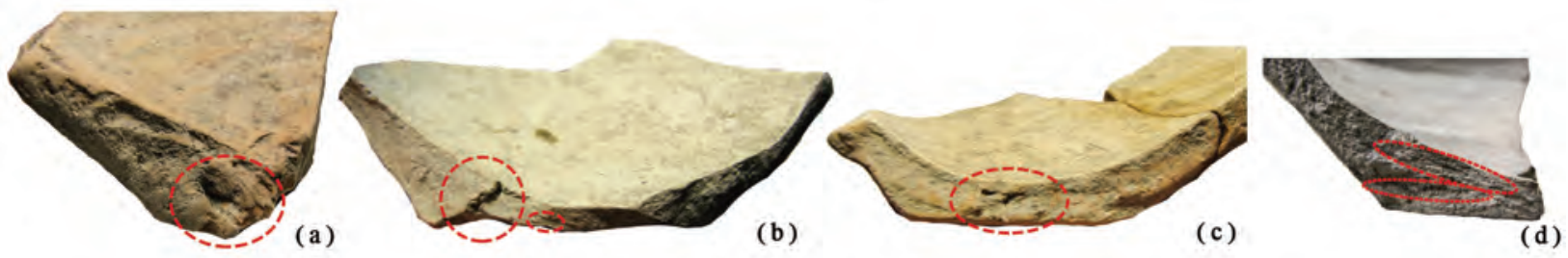

Fig. 16 Ayios Vasileios. Macro-features indicative of bases made by a spiraled coil or a slab: (a) 6AV; (b) 198AV; (c) 81AV; (d) 268AV (Photos by M. Choleva) 
build up the body of the bowl with coils (Fig. 17g-h), following the operations identified in other open shapes, i.e. joining the coils, thinning and shaping the roughout by RKE. The bottom-up construction of kylikes and goblets is suggested by the following evidence: the upper edge of the stem of many pots present a 'pointed'-like shape, which seems to 'serve' a kind of surface for joining the coils of the bowl's body. Coil seams observed on this joining area between the stem and the body run around the aforementioned edge, thus indicating the building of the bowl on the stem (see Fig. 17d-g). The absence of expected torsional ripples (see below) suggests that this operation is executed either without the involvement of RKE or with the use of very low speeds. Once the roughout stage has been completed, the various vessels are submitted to different finishing operations. The most common surface treatment is smoothing/wiping the surface by RKE when humid, as the fine and dense striations on

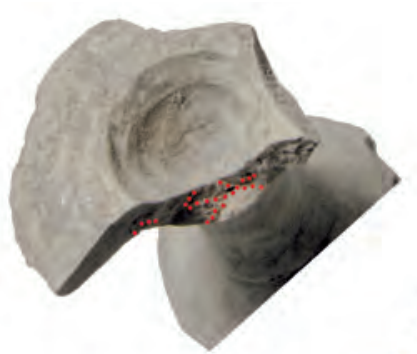

(a)

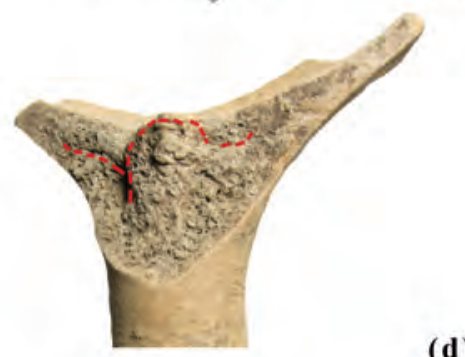

(d)

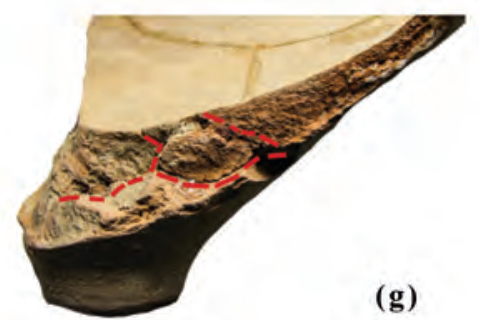

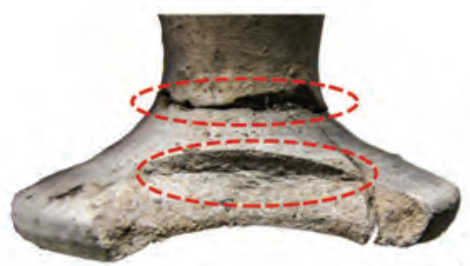

(b)

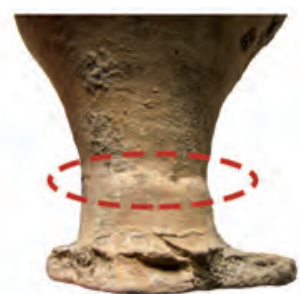

(c)

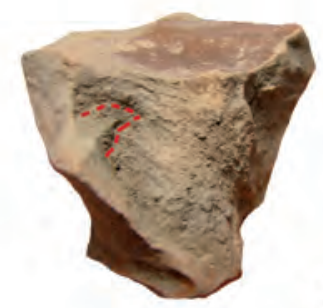

(f)

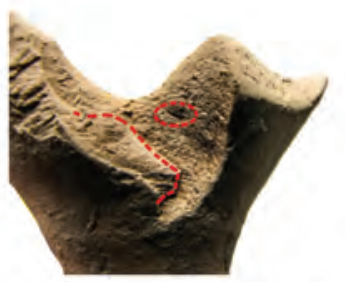

(i)

Fig. 17 Ayios Vasileios. Macro-features indicative of forming operations involved in composite shapes: (a) 25AV; (b) 176AV; (c) 38AV; (d) 19AV; (e) 121AV; (f) 59AV; (g) 197AV; (h) 176AV; (i) 132AV (Photos by M. Choleva)
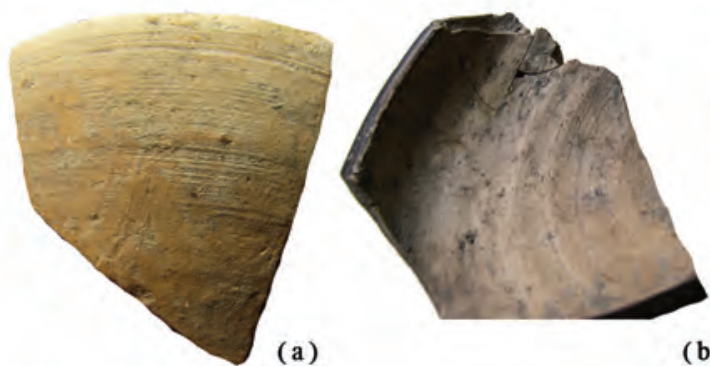

(b)

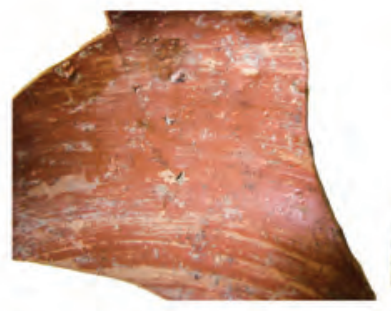

(c)

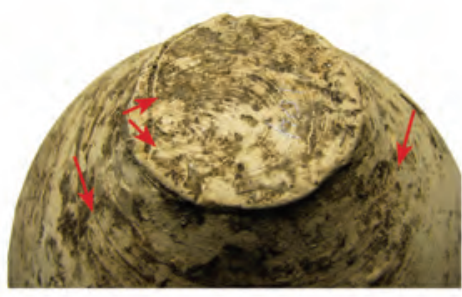

(d)

Fig. 18 Ayios Vasileios. Macro-features indicative RKE finishing operations: (a) 189AV; (b) 273AV (XRay sample 14); (c) 270AV (XRay sample 11); (d) 2AV (Photos by M. Choleva) 


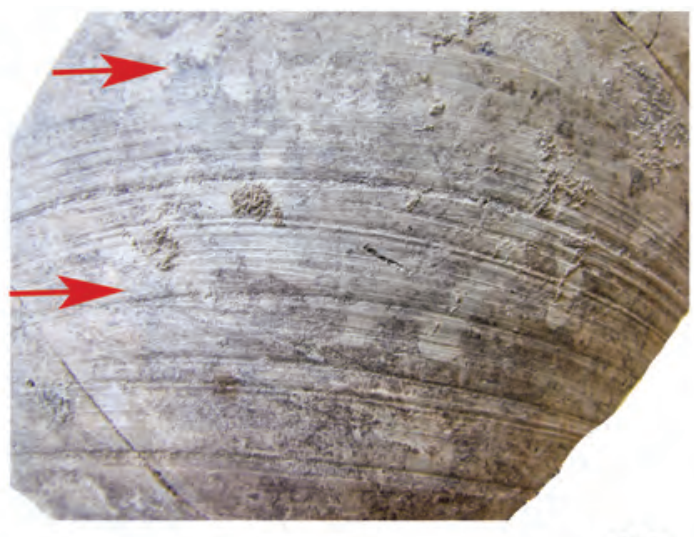

(a)

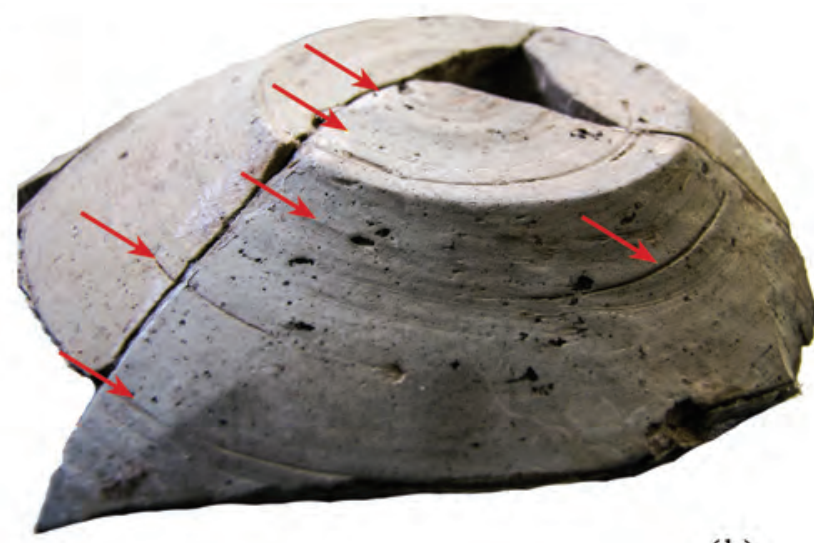

(b)

Fig. 19 Ayios Vasileios. Macro-features indicative of turning: (a) 266AV (XRay sample 7); (b) 274AV (XRay sample 16) (Photos by M. Choleva)

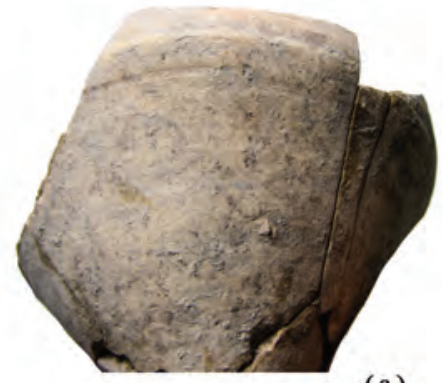

(a)

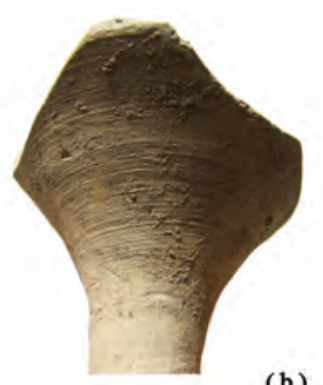

(b)

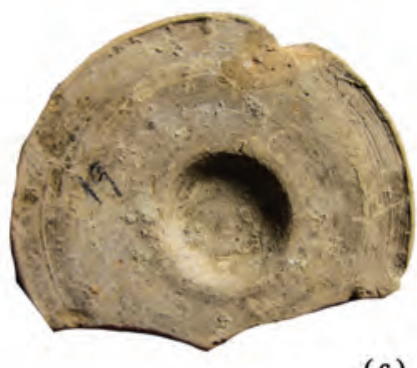

(c)

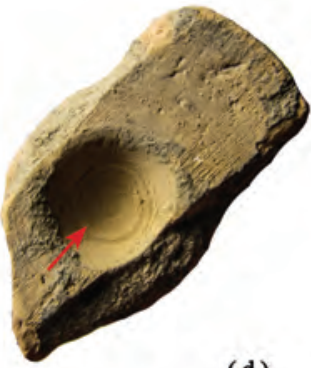

(d)

Fig. 20 Ayios Vasileios. Macro-features indicative of finishing operations involved in composites shapes: (a) 107AV; (b) 35AV; (c) 76AV; (d) 132AV (Photos by M. Choleva)

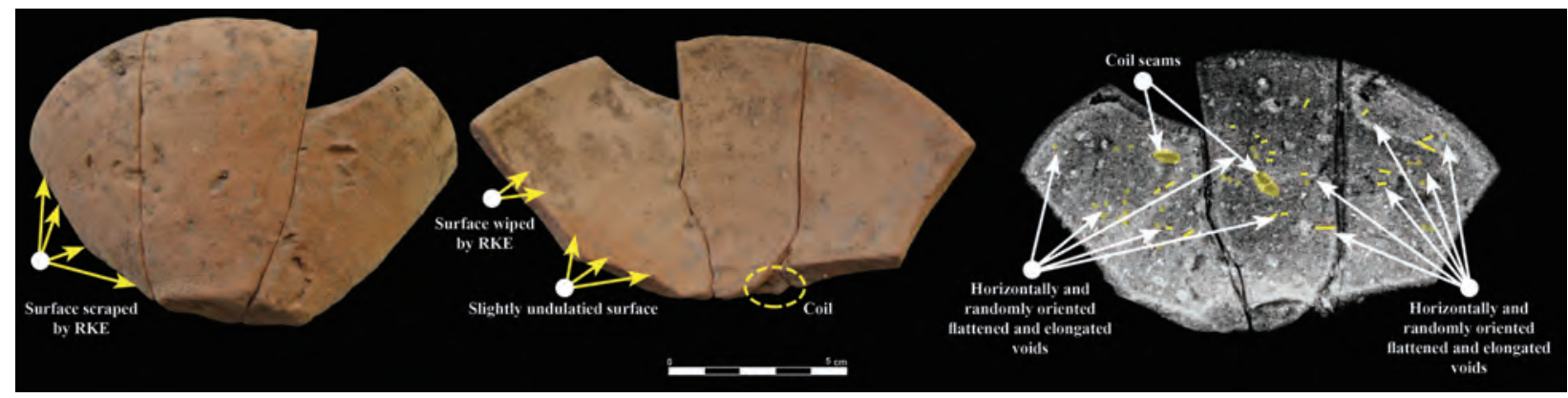

Fig. 21 Ayios Vasileios. Example of the chaîne opératoire LAC2 (267AV - XRay sample 8) (Photo by M. Choleva) (XRay by I. Basourakos, medical center Sparta)

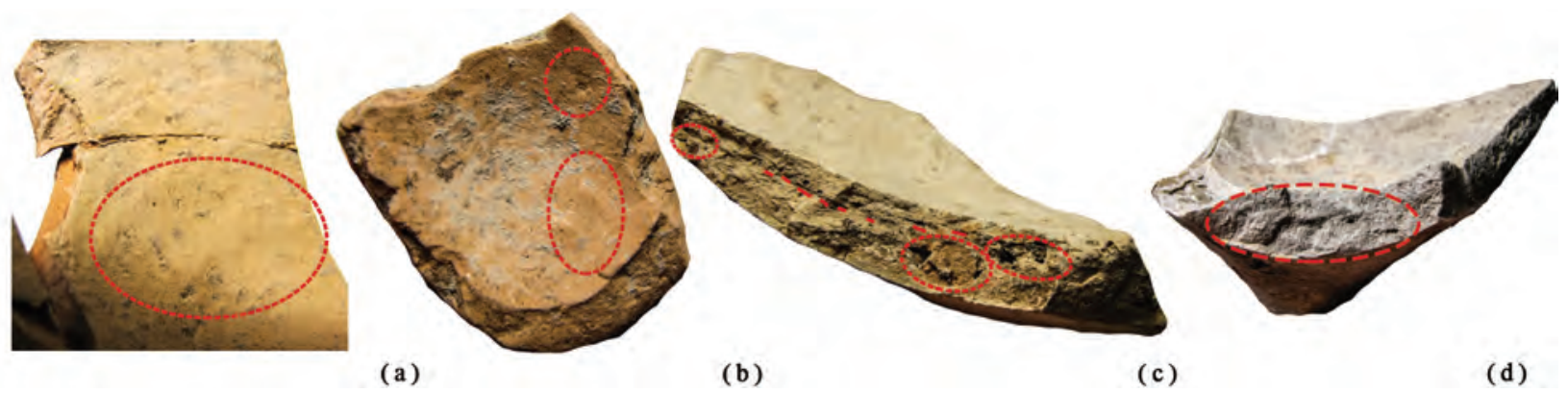

Fig. 22 Ayios Vasileios. Macro-features indicative of the wheel-coiling method 1: (a) 61AV; (b) 68AV; (c) 172AV; (d) 109AV (Photos by M. Choleva) 
the interior and exterior surfaces indicate (Fig. 18a-c). Especially the conical cups are detached from the wheel while rotating with a string (semi-circular striations underneath) (Fig. 18d). A few pots, however, are treated in a different way. Some bowls and cups are placed upside-down and are turned when leather hard (scraped while rotating) to regularize the lower part; this operation creates deep and sharp horizontal and rectilinear striations on surfaces and concentric striations underneath the base (Fig. 19a-b). For the kylikes and goblets, it seems that all the parts of the vessels are finally wiped in tandem through slow rotations that leave fine superficial striations all over the surfaces (Fig. 20a-b). At some final stage of the finishing operations, these pots must have been placed upside down and treated on the wheel, as the dome and the concentric striations made by RKE underneath the disc suggest (Fig. 20c-d).

(b) Chaîne opératoire LAC 2 (Fig. 21): This chaîne sporadically occurs among fine and medium fine plain conical cups and kylikes and among some painted vessels such as goblets or cups, and thus overlaps in its shape repertoire with that of the preceding chaîne LAC 1 (see
Tab. 9). However, the vessels of chaîne LAC 2 are made according to the wheel-coiling method 1: the coils are formed and joined, and the roughout is thinned by discontinuous pressures (Fig. 22c-d). RKE is only used during the final operation of shaping the roughout. The pots are thus only slightly modified by RKE (Fig. 22cd). The ways of forming the bases vary as in the case of the previous chaîne: bases are made either of a slab (Fig. 23a) or a spiral coil (Fig. 23b). Most of the pots are wiped with the help of RKE (Fig. 24a) whereas some of them are either self-slipped (i.e. covered by a thin layer of clay) and left untreated by any subsequent finishing operation (Fig. 24b) or smoothed without RKE (Fig. 24c). The pots, especially the conical cups, are removed from the wheel while rotating (see Fig. 24b), whereas the kylikes seem to be made in the same way as those of the chaîne LAC 1 (Fig. 25a-b).

(c) Chaîne opératoire LAC 3 (Fig. 26): This rare chaine is identified by a variation of the wheelcoiling method 1 and is represented by a single sample, belonging to a medium coarse cooking tripod. The wheel seems to be involved in the very end of the manufacturing process for shaping the preform of the vessel. The identi-

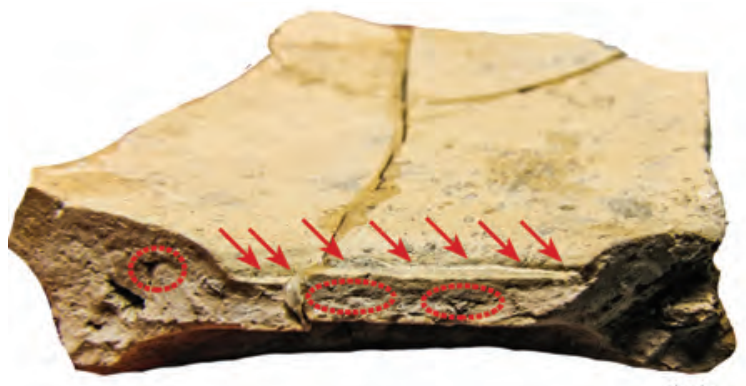

(a)

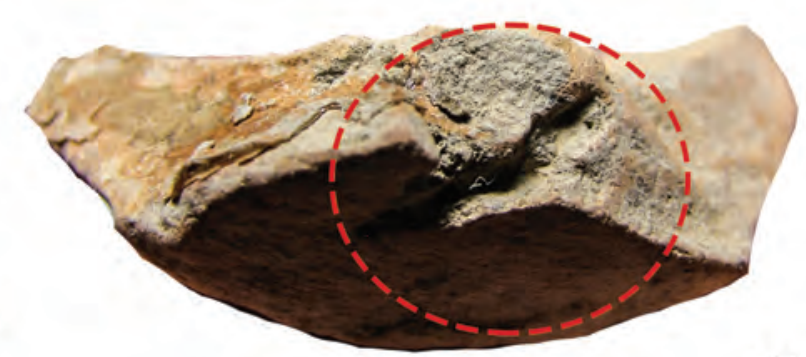

(b)

Fig. 23 Ayios Vasileios. Macro-features indicative of bases made by a spiraled coil or a slab: (a) 79AV; (b) 83AV (Photos by M. Choleva)

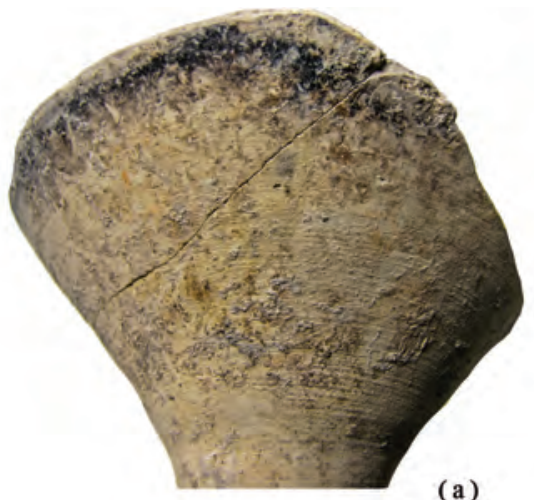

(a)

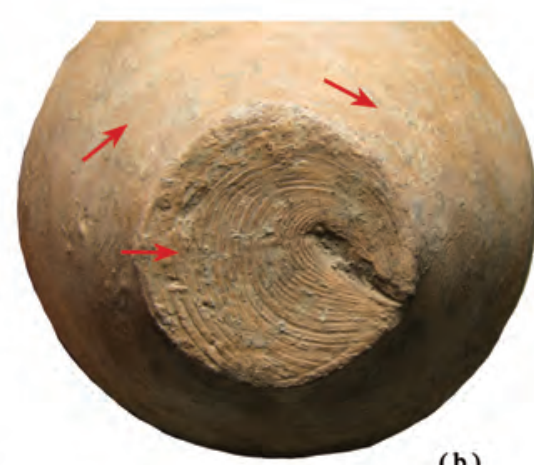

(b)

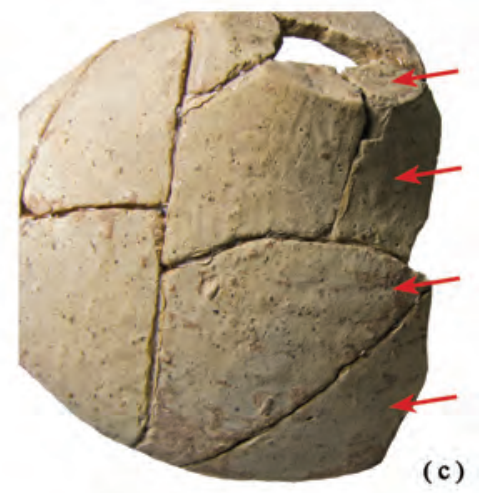

(c)

Fig. 24 Ayios Vasileios. Macro-features indicative of finishing operations: (a) 89AV; (b) 102AV; (c) 175AV (Photos by M. Choleva) 


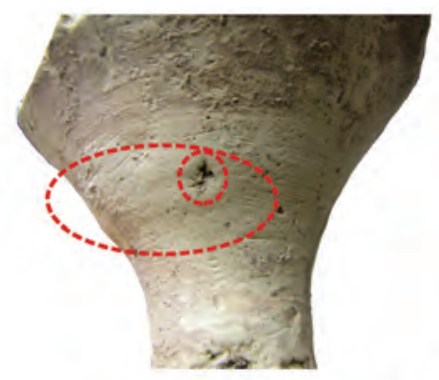

(a)

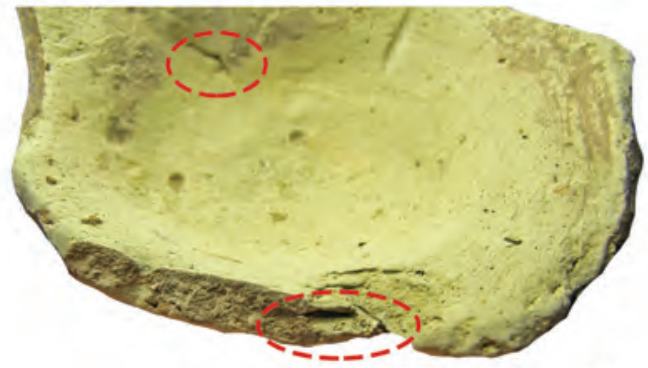

(b)

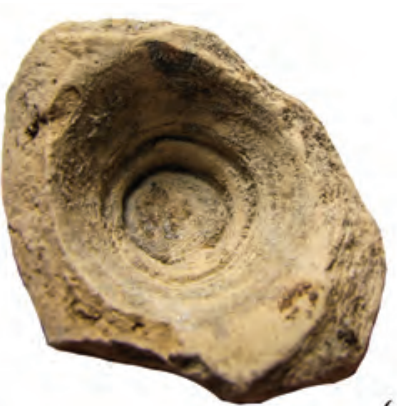

(c)

Fig. 25 Ayios Vasileios. Macro-features indicative of forming operations involved in composite shapes: (a) 156AV; (b) 156AV; (c) 31AV (Photos by M. Choleva)

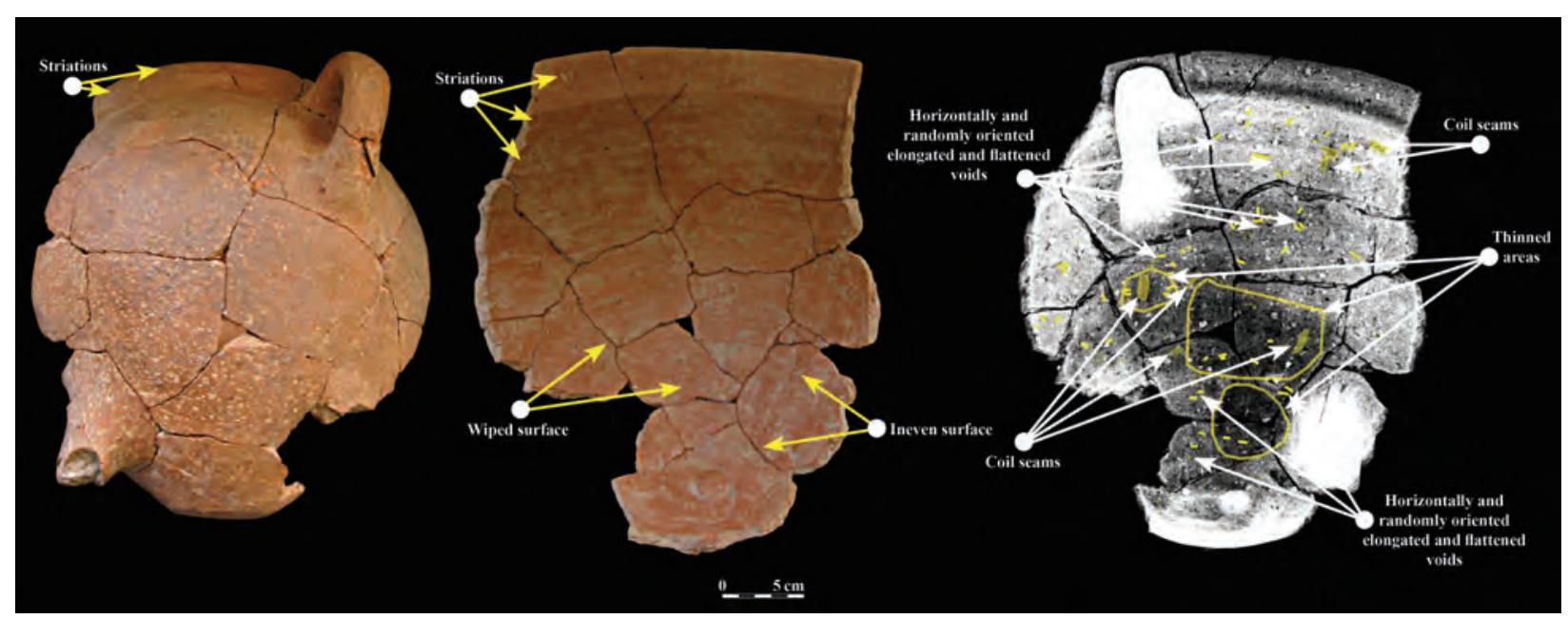

Fig. 26 Ayios Vasileios. Example of the chaîne opératoire LAC3 (276AV - XRay sample 18) (Photo by M. Choleva) (XRay by I. Basourakos, medical center Sparta)

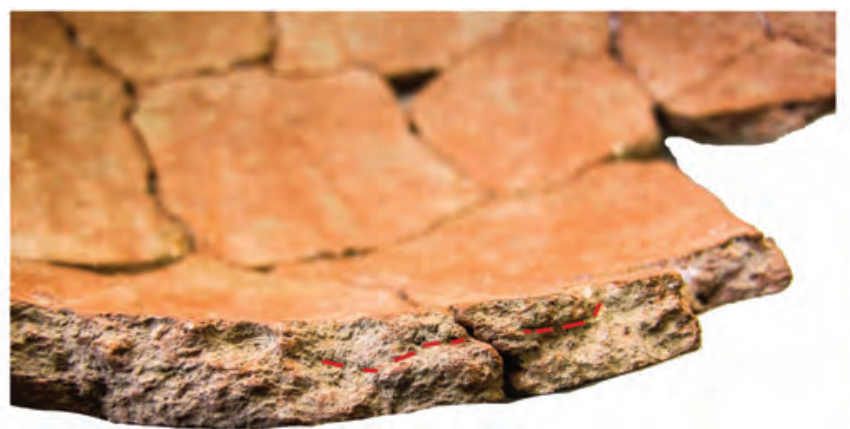

(a)

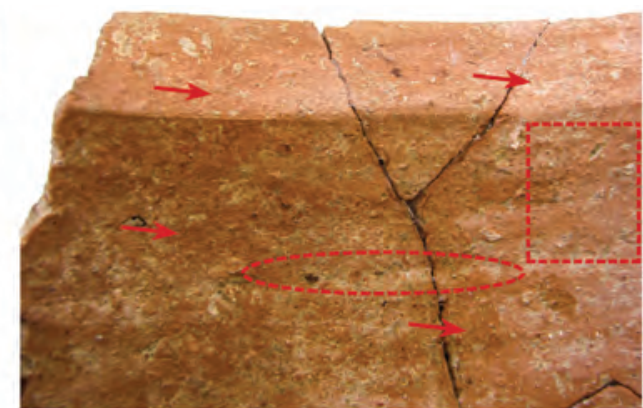

(b)

Fig. 27 Ayios Vasileios. Macro-features indicative of a variation of the wheel-coiling method 1: (a-b) 276AV (XRay sample 18) (Photos by M. Choleva)

fied macro-features like fine horizontal and superficial striations rather suggest a rotational movement enacted by the hands on a support and not necessarily by a potter's wheel able to produce RKE (Fig. 27b). The roughout of this pot is probably made by big coils. However, the randomly distributed elongated voids along with long horizontal joints on breaks could also indicate the use of slabs (Fig. 27a). ${ }^{139}$ After being regularized by rotational movement, the pot is then submitted to finishing operations such as smoothing without RKE.

139 For microtraces related to slab-building, see VANDIVER 1987. 


\subsubsection{Craft behaviours over time}

The identification of three chaînes opératoires within the wheelmade production at Ayios Vasileios reveals distinct levels of technical specialization embedded in the use of the wheel, each one implying different craft behaviours that seem to have varied slightly over time (Tabs. 10-11).

The chaîne LAC 1 (method 3) is founded on well-coordinated and organized gestures mediated by RKE that imply a specific set of specialized motor and cognitive skills activating the manufacturing process. These skills correspond to a specific know-how that merges the coiling operations with usage of the wheel from an early stage of the forming process. This technical knowledge characterizes a highly specialized craft behaviour that underlies the manufacture of a wide spectrum of shapes over time, mainly belonging to fine to medium fine vessels. This craft behaviour is con- firmed since LH IIB whereas it represents the commonest forming technology enacting the wheelmade production throughout LH IIIA in the course of which the wheel-based typology has been considerably enlarged (see Tab. 10). It also occurs in the only pot of LH IIIB2/IIIC Early date among the wheelmade vessels that we have examined for this study (see Tab. 11).

The chaîne LAC 2 (method 1), in turn, is grounded in an 'elementary' knowledge of the potter's wheel which is inserted in the manufacturing process only during the final stage of the primary forming process. It is therefore associated with a craft behaviour that is mostly founded on gestures that are not mediated by RKE. Contrary to chaîne LAC 1, the gestures related to the mastery of RKE during shaping operations in LAC 2 imply a lower technical specialization and are related to a set of motor and cognitive skills specific to a craft behaviour founded on less familiarity with the
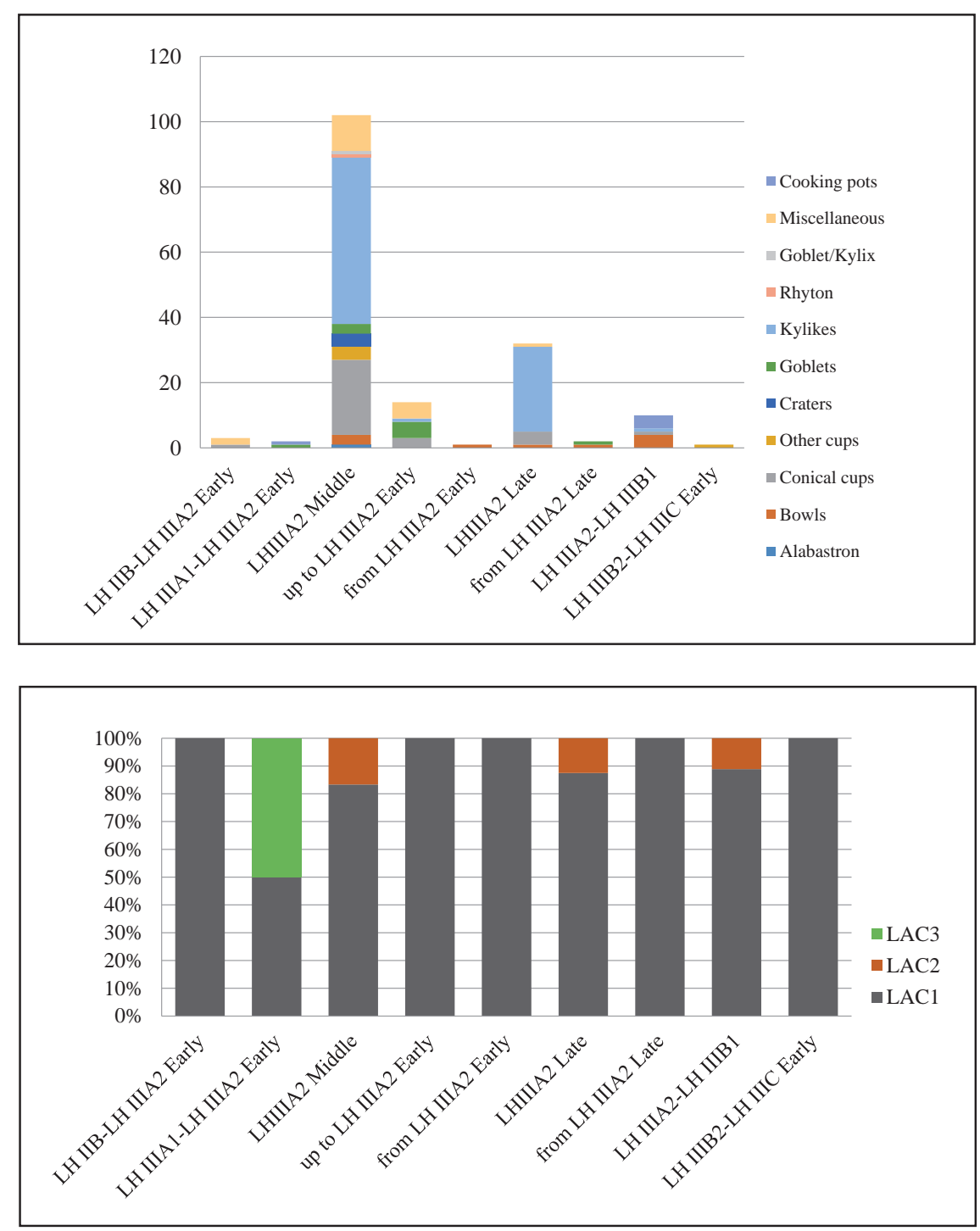

Table 10 Ayios Vasileios. Wheelmade shapes over time

Table 11 Ayios Vasileios. Chaînes opératoires over studied phases 
potter's wheel. This craft behaviour is marginal within the studied assemblage and it is associated with pots dating to LH IIIA2-IIIB1, whereas it occurs in a limited range of shapes which are all typical of the chaîne LAC 1.

Finally, the chaîne LAC 3 (variation of method 1) is founded on a craft behaviour that is exclusively built upon gestures not mediated by RKE. The use of the wheel is exploited only to regularize the surfaces and it does not necessarily imply some specialized knowledge of the potter's wheel. The underlying craft behaviour is related to a different kind of pottery in terms of both morphostylistic types and fabrics and it is associated with the manufacture of one medium coarse cooking tripod of a micaceous fabric closely related to Kytheran and Cretan pottery traditions.

\subsection{Comparative data from the Argolid}

The potting technology underlying wheelmade production in the Argolid has been explored through the macroscopic examination of 26 selected vessels and vessel fragments from Tiryns and 7 vessel fragments from Tall Zirāaca (Tabs. 12-13). The analysis has been completed by X-ray analysis of the 7 samples from Tall Zirāca. The examined pottery mostly belongs to fine wares, both painted and plain, and they include deep bowls, cups, stemmed bowls, one goblet, kylikes, kraters, alabastra, stirrup jars, piriform jars and cooking pots.

The finds from Tiryns predominantly consist of vessels produced either in the last phase of the palace period (LH IIIB Final, 15 samples) or in the earliest phase of the post-palatial period (LH IIIC Early 1, 7 samples). They were all found in the layers stratified on top of the Western Staircase, a main ascent to the Upper Citadel ${ }^{140}$. These include painted and unpainted fine ware vessels as well as medium coarse cooking pots (Fig. 43). In addition, we examined four painted fine-ware vessels found on the Lower Citadel in strata belonging to earlier phases of the palace period (LH IIIB Early and LH IIIB Middle) (Tab. 12). ${ }^{141}$ According to our macroscopic examination, one group of these Tirynthian finds belongs to fabrics examples of which could be assigned to the northern Argolid by means of NAA in other research projects (chemical group MYBE) (Tab. 12, 4, 6-7, 9-10, 25-26). ${ }^{142}$ Another

\footnotetext{
${ }^{140}$ For that stratigraphy see KARDAMAKI 2009; KARDAMAKI 2015b.

141 SCHÖNFELD 1988.
}

group of painted vessels show slightly different fabric characteristics and may represent local products of the southern Argolid, the region of Tiryns itself (see Tab. 12 for description of fabrics).

All the Mycenaean fragments found at the site of Tall Zirāca, which is situated to the east of the Jordan valley, come from disturbed settlement contexts. ${ }^{143}$ Yet, they can be typologically dated and belong to the early and developed palatial period. More specifically, five vessels are certainly or with high probability LH IIIA1 products (Fig. 44.1-4, 6), while two were most probably made during LH IIIA2 (Fig. 44.5, 7). Chemical analyses (NAA) conducted by Hans Mommsen revealed the production regions for three of these vessels, which all date to LH IIIA1. A kylix and a medium-sized piriform jar (samples 5TZ and 8TZ) show the characteristic chemical pattern of the northern Argolid (MYBE), while a goblet (sample 6TZ) came from the southern Argolid (chemical pattern TIR). Those four for which no NAA results are available (samples 1TZ, 2TZ, 4TZ and 7TZ), can all be assigned to the northern Argolid based on the fabric similarity they exhibit in comparison with the two MYBE samples. In conclusion, we can take the seven Tall Zirāa a vessels as representative of Argive painted fine wares made during the early to developed palace period. Furthermore, their find place in Jordan suggests that they represent products of those very workshops in the Argolid that became mainly engaged in a specialized export production from LH IIIA onwards.

4.2.1. The macroscopic and X-Ray examination of the Argive wheelmade pottery

\section{Macro- and micro-features}

As at Ayios Vasileios, the macroscopic analysis of pottery from Tiryns and Tall Zirāa a revealed the use of the wheel-coiling technique instead of wheel-throwing. On the one hand, the studied material from both sites is macroscopically characterized by the presence of concentric parallel deep undulations in the form of bands, uniform relief and regular profiles, suggesting strongly modified roughouts under the impact of RKE (Fig. 28). Horizontal rectilinear dense striations

\footnotetext{
142 Demakopoulou et AL. 2017.

143 JunG Forthcoming.
} 
Table 12 Catalogue of the samples examined through macroscopic analysis at Tiryns. Density of inclusions is described as "occasional, some, frequent, high" following Rutter 1993. Size of inclusions: dust size, small ( $<2 \mathrm{~mm})$, medium $(2-4 \mathrm{~mm})$, big $(>4 \mathrm{~mm})$. For colour of clay and surfaces in fine painted ware see Kardamaki 2009. In fine plain Munsell colours vary between light red, red and light brown. Surfaces in fine plain classified as: rough (wheel marks visible), standard (wheel marks smoothed), polished

(cf. WARDLE 1969, 281).

\begin{tabular}{|c|c|c|c|c|c|c|c|c|c|}
\hline $\begin{array}{c}\text { Sample } \\
\text { no. }\end{array}$ & $\begin{array}{l}\text { Roux's } \\
\text { method }\end{array}$ & Chaîne & Shape & Category & Fabric code & Context & Chronology & Figure & $\begin{array}{c}\text { Publication } \\
\text { reference }\end{array}$ \\
\hline $1 \mathrm{Ti}$ & M3 & ARG1 & $\begin{array}{l}\text { Deep bowl } \\
\text { A FS } 284\end{array}$ & $\begin{array}{l}\text { Fine } \\
\text { painted } \\
\text { (lustrous } \\
\text { paint) }\end{array}$ & $\begin{array}{l}\text { cf. Jung } 2008, \text { M10-13 for } \\
\text { colors, but with small white } \\
\text { soft, gray, brown particles } \\
\text { (density: "occasional” to } \\
\text { "some”) (very rarely size of } \\
\text { inclusions between 2-4 mm) }\end{array}$ & $\begin{array}{l}\text { Western } \\
\text { staircase, } \\
\text { Zone } 2\end{array}$ & $\begin{array}{l}\text { LH IIIB2 } \\
\text { Late }\end{array}$ & $\begin{array}{l}\text { 30d, } \\
32 a\end{array}$ & $\begin{array}{l}\text { KARDAMAKI } \\
2009, \\
\text { pl. } 4.74\end{array}$ \\
\hline $2 \mathrm{Ti}$ & M3 & ARG1 & $\begin{array}{l}\text { Pictorial } \\
\text { Crater } \\
\text { FS } 281\end{array}$ & $\begin{array}{l}\text { Fine } \\
\text { painted } \\
\text { (lustrous } \\
\text { paint) }\end{array}$ & cf. sample no. 1 & $\begin{array}{l}\text { Western } \\
\text { staircase, } \\
\text { Zone } 2\end{array}$ & $\begin{array}{l}\text { LH IIIB2 } \\
\text { Late }\end{array}$ & $28 \mathrm{c}$ & $\begin{array}{l}\text { KARDAMAKI } \\
2009, \\
\text { pl. } 11.147\end{array}$ \\
\hline $3 T i$ & M3 & ARG1 & $\begin{array}{l}\text { Large deep } \\
\text { bowl A } \\
\text { FS } 284\end{array}$ & $\begin{array}{l}\text { Fine } \\
\text { painted } \\
\text { (lustrous } \\
\text { paint) }\end{array}$ & $\begin{array}{l}\text { red clay/slip, small white } \\
\text { soft, gray, brown particles } \\
\text { (density: “occasional”) }\end{array}$ & $\begin{array}{l}\text { Western } \\
\text { staircase, } \\
\text { Zone 2/1 }\end{array}$ & \begin{tabular}{|l|} 
LH IIIB2 \\
Late/LH \\
IIIC Early 1
\end{tabular} & $35 b$ & $\begin{array}{l}\text { KARDAMAKI } \\
2009, \\
\text { pl. } 12.171\end{array}$ \\
\hline $4 \mathrm{Ti}$ & M3 & ARG1 & $\begin{array}{l}\text { Medium } \\
\text { band } \\
\text { Cup } \\
\text { FS } 215\end{array}$ & $\begin{array}{l}\text { Fine } \\
\text { painted } \\
\text { (lustrous } \\
\text { paint) }\end{array}$ & cf. Jung 2008, fabric M10 & $\begin{array}{l}\text { Western } \\
\text { staircase, } \\
\text { Zone } 1\end{array}$ & $\begin{array}{l}\text { LH IIIC } \\
\text { Early } 1\end{array}$ & 39d & $\begin{array}{l}\text { KARDAMAKI } \\
2009, \\
\text { pl. } 27.574\end{array}$ \\
\hline $5 \mathrm{Ti}$ & M3 & ARG1 & $\begin{array}{l}\text { Deep bowl } \\
\text { A FS } 284\end{array}$ & $\begin{array}{l}\text { Fine } \\
\text { painted } \\
\text { (lustrous } \\
\text { paint) }\end{array}$ & cf. sample no. 1 & $\begin{array}{l}\text { Western } \\
\text { Staircase, } \\
\text { Zone } 1\end{array}$ & $\begin{array}{l}\text { LH IIIC } \\
\text { Early } 1\end{array}$ & $\begin{array}{l}29 b, \\
32 b\end{array}$ & $\begin{array}{l}\text { KARDAMAKI } \\
2009, \\
\text { pl. } 17.329\end{array}$ \\
\hline $6 \mathrm{Ti}$ & M3 & ARG1 & $\begin{array}{l}\text { Small } \\
\text { stirrup jar }\end{array}$ & $\begin{array}{l}\text { Fine } \\
\text { painted } \\
\text { (lustrous } \\
\text { paint) }\end{array}$ & cf. Jung 2008, fabric M10 & $\begin{array}{l}\text { Western } \\
\text { Staircase, } \\
\text { Zone } 1\end{array}$ & $\begin{array}{l}\text { LH IIIC } \\
\text { Early } 1\end{array}$ & $38 \mathrm{c}$ & $\begin{array}{l}\text { Kardamaki } \\
\text { 2009, } \\
\text { pl. } 16.269\end{array}$ \\
\hline $7 \mathrm{Ti}$ & M3 & ARG1 & $\begin{array}{l}\text { Stemmed } \\
\text { bowl } \\
\text { FS } 304\end{array}$ & $\begin{array}{l}\text { Fine } \\
\text { painted } \\
\text { (lustrous } \\
\text { paint) }\end{array}$ & cf. Jung 2008, fabric M10 & $\begin{array}{l}\text { Western } \\
\text { staircase, } \\
\text { Zone } 1\end{array}$ & $\begin{array}{l}\text { LH IIIBC } \\
\text { Early } 1\end{array}$ & & $\begin{array}{l}\text { KARDAMAKI } \\
2009, \\
\text { pl. } 15.231\end{array}$ \\
\hline $8 \mathrm{Ti}$ & M3 & ARG1 & $\begin{array}{l}\text { Closed } \\
\text { vessel }\end{array}$ & \begin{tabular}{|l} 
Fine \\
painted \\
(lustrous \\
paint)
\end{tabular} & Cf. sample no. 1 & $\begin{array}{l}\text { Western } \\
\text { staircase, } \\
\text { Zone } 1 \\
\text { (context nr. } \\
\text { 1574, 1291) }\end{array}$ & $\begin{array}{l}\text { LH IIIBC } \\
\text { Early } 1\end{array}$ & $32 \mathrm{c}$ & \\
\hline $9 \mathrm{Ti}$ & M3 & ARG1 & $\begin{array}{l}\text { Small } \\
\text { stirrup jar }\end{array}$ & \begin{tabular}{|l} 
Fine \\
painted \\
(lustrous \\
paint)
\end{tabular} & cf. Jung 2008, fabric M10 & $\begin{array}{l}\text { Western } \\
\text { staircase, } \\
\text { Zone } 2\end{array}$ & $\begin{array}{l}\text { LH IIIB2 } \\
\text { Late }\end{array}$ & 43.1 & $\begin{array}{l}\text { KARDAMAKI } \\
2009, \\
\text { pl. } 6.116\end{array}$ \\
\hline $10 \mathrm{Ti}$ & M3 & ARG1 & $\begin{array}{l}\text { Closed } \\
\text { vessel }\end{array}$ & \begin{tabular}{|l} 
Fine \\
painted \\
(lustrous \\
paint)
\end{tabular} & cf. Jung 2008, fabric M10 & $\begin{array}{l}\text { Western } \\
\text { staircase, } \\
\text { Zone } 1\end{array}$ & $\begin{array}{l}\text { LH IIIC } \\
\text { Early } 1\end{array}$ & $29 a$ & $\begin{array}{l}\text { KARDAMAKI } \\
2009, \\
\text { pl. } 32.704\end{array}$ \\
\hline
\end{tabular}




\begin{tabular}{|c|c|c|c|c|c|c|c|c|c|}
\hline $\begin{array}{c}\text { Sample } \\
\text { no. }\end{array}$ & $\begin{array}{l}\text { Roux's } \\
\text { method }\end{array}$ & Chaîne & Shape & Category & Fabric code & Context & Chronology & Figure & $\begin{array}{c}\text { Publication } \\
\text { reference }\end{array}$ \\
\hline $11 \mathrm{Ti}$ & M3 & ARG1 & $\begin{array}{l}\text { Deep bowl } \\
\text { A with } \\
\text { dotted rim } \\
\text { FS } 284\end{array}$ & $\begin{array}{l}\text { Fine } \\
\text { painted }\end{array}$ & Cf. sample no. 1 & $\begin{array}{l}\text { Western } \\
\text { Staircase, } \\
\text { Zone } 1\end{array}$ & $\begin{array}{l}\text { LH IIIC } \\
\text { Early } 1\end{array}$ & 43.5 & $\begin{array}{l}\text { KARDAMAKI } \\
2009, \\
\text { pl. } 21.442\end{array}$ \\
\hline $12 \mathrm{Ti}$ & M3 & ARG1 & $\begin{array}{l}\text { Rosette } \\
\text { deep } \\
\text { bowl } \\
\text { FS } 284\end{array}$ & $\begin{array}{l}\text { Fine } \\
\text { painted }\end{array}$ & $\begin{array}{l}\text { very fine, no visible } \\
\text { inclusions }\end{array}$ & $\begin{array}{l}\text { Western } \\
\text { staircase, } \\
\text { Zone 2/1 }\end{array}$ & $\begin{array}{l}\text { LH IIIB2 } \\
\text { Late/LH } \\
\text { IIIC Early } 1\end{array}$ & & $\begin{array}{l}\text { KARDAMAKI } \\
2009, \\
\text { pl. } 12.172\end{array}$ \\
\hline 13Ti & M3 & ARG1 & $\begin{array}{l}\text { Carin. } \\
\text { kylix } \\
\text { FS } 267\end{array}$ & Fine Plain & $\begin{array}{l}\text { rough surface, small } \\
\text { white soft, dark inclusions } \\
\text { (density: "occasional”) } \\
\text { (size of inclusions rarely } \\
\text { between } 2-4 \text { or }>4 \text { mm); } \\
\text { silver sparkling dust } \\
\text { size inclusions (density: } \\
\text { "occasional”) }\end{array}$ & $\begin{array}{l}\text { Western } \\
\text { staircase, } \\
\text { Zone } 2 \\
\text { (context nr. } \\
\text { 1523, 1587, } \\
1612 \text { ) }\end{array}$ & $\begin{array}{l}\text { LH IIIB2 } \\
\text { Late }\end{array}$ & $\begin{array}{l}30 \mathrm{~b}, \\
32 \mathrm{f}, \\
37 \mathrm{a}-\mathrm{b}, \\
\mathrm{g}\end{array}$ & \\
\hline $14 \mathrm{Ti}$ & M3 & ARG1 & $\begin{array}{l}\text { Ang. Bowl } \\
\text { FS } 295\end{array}$ & Fine Plain & $\begin{array}{l}\text { standard/rough surfaces, } \\
\text { soft, dark inclusions } \\
\text { (density: "occasional” to } \\
\text { "some”) (size of inclusions } \\
\text { rarely between } 2-4 \text { or }>4 \\
\text { mm); silver sparkling dust } \\
\text { size inclusions (density: } \\
\text { "some”) }\end{array}$ & $\begin{array}{l}\text { Western } \\
\text { staircase, } \\
\text { Zone } 2 \\
\text { (context nr. } \\
\text { 1441, 1389) }\end{array}$ & $\begin{array}{l}\text { LH IIIB2 } \\
\text { Late }\end{array}$ & 29c & \\
\hline $15 \mathrm{Ti}$ & M3 & ARG1 & $\begin{array}{l}\text { Ang. Bowl } \\
\text { FS } 295\end{array}$ & Fine Plain & $\begin{array}{l}\text { standard/rough surfaces, } \\
\text { soft, dark inclusions } \\
\text { (density: “occasional” to } \\
\text { "some") }\end{array}$ & $\begin{array}{l}\text { Western } \\
\text { staircase, } \\
\text { Zone } 2 \\
\text { (context nr. } \\
1441,1475, \\
1549,1558)\end{array}$ & $\begin{array}{l}\text { LH IIIB2 } \\
\text { Late }\end{array}$ & $30 a$ & \\
\hline $16 \mathrm{Ti}$ & M3 & ARG1 & Kylix & Fine plain & $\begin{array}{l}\text { standard/rough surface, } \\
\text { small white soft, dark } \\
\text { inclusions (density: } \\
\text { "occasional” to “some”) }\end{array}$ & $\begin{array}{l}\text { Western } \\
\text { staircase, } \\
\text { Zone } 2 \\
\text { (context nr. } \\
\text { 1490, 1487) }\end{array}$ & $\begin{array}{l}\text { LH IIIB2 } \\
\text { Late }\end{array}$ & \begin{tabular}{|l|}
$28 a$, \\
$37 f, h$, \\
$39 a$
\end{tabular} & \\
\hline $18 \mathrm{Ti}$ & M3 & ARG1 & $\begin{array}{l}\text { Carin. } \\
\text { kylix } \\
\text { FS } 267\end{array}$ & Fine Plain & $\begin{array}{l}\text { standard surface, small and } \\
\text { very rarely big ( }>4 \text { mm) } \\
\text { white soft, dark inclusions } \\
\text { (density: “occasinal”); } \\
\text { silver sparkling dust } \\
\text { size inclusions (density: } \\
\text { "occasional”) }\end{array}$ & $\begin{array}{l}\text { Western } \\
\text { staircase, } \\
\text { Zone } 2 \\
\text { (context nr. } \\
1231,1291, \\
1362,1364, \\
1444)\end{array}$ & $\begin{array}{l}\text { LH IIIB2 } \\
\text { Late }\end{array}$ & $\begin{array}{l}\text { 31a, } \\
32 e, \\
37 e\end{array}$ & \\
\hline 19Ti & M3 & ARG1 & $\begin{array}{l}\text { Cup } \\
\text { FS } 220\end{array}$ & Fine Plain & $\begin{array}{l}\text { standard/rough surface, } \\
\text { small white soft, dark } \\
\text { inclusions (density: } \\
\text { “occasinal”); silver sparkling } \\
\text { dust size inclusions (density: } \\
\text { "occasional”) }\end{array}$ & $\begin{array}{l}\text { Western } \\
\text { staircase, } \\
\text { Zone } 2 \\
\text { (context nr. } \\
1509,1524, \\
1459,1487, \\
1458)\end{array}$ & $\begin{array}{l}\text { LH IIIB2 } \\
\text { Late }\end{array}$ & $39 b$ & \\
\hline
\end{tabular}


Working on the potter's whed: technol ogical insights into Mycenaean Pottery production 257

\begin{tabular}{|c|c|c|c|c|c|c|c|c|c|}
\hline $\begin{array}{c}\text { Sample } \\
\text { no. }\end{array}$ & $\begin{array}{l}\text { Roux's } \\
\text { method }\end{array}$ & Chaîne & Shape & Category & Fabric code & Context & Chronology & Figure & $\begin{array}{c}\text { Publication } \\
\text { reference }\end{array}$ \\
\hline $\begin{array}{c}20 \mathrm{Ti}- \\
21 \mathrm{Ti}\end{array}$ & M3 & ARG1 & $\begin{array}{l}\text { Cook. pot } \\
\text { Local }\end{array}$ & $\begin{array}{l}\text { Medium } \\
\text { coarse } \\
\text { Local } \\
\text { (wheel- } \\
\text { made) }\end{array}$ & $\begin{array}{l}\text { sandy clay, small inclusions } \\
\text { (size rarely between 2-4) } \\
\text { (density “occasional”, rarely } \\
\text { "some”) }\end{array}$ & $\begin{array}{l}\text { Western } \\
\text { staircase, } \\
\text { Zone } 2 \\
\text { (context nr. } \\
\text { 20Ti: 1444, } \\
\text { 1362, 1513, } \\
\text { 1464 and } \\
\text { 21Ti: 1362, } \\
\text { 1260) }\end{array}$ & $\begin{array}{l}\text { LH IIIB2 } \\
\text { Late }\end{array}$ & $\begin{array}{l}28 d, \\
30 c, \\
36 b\end{array}$ & \\
\hline $22 \mathrm{Ti}$ & M3 & ARG1 & Kylix & Fine Plain & $\begin{array}{l}\text { rough surface, small and } \\
\text { very rarely big ( }>4 \text { mm) } \\
\text { white soft, dark inclusions } \\
\text { (density: “occasinal”); } \\
\text { silver sparkling dust } \\
\text { size inclusions (density: } \\
\text { "occasional”) }\end{array}$ & $\begin{array}{l}\text { Western } \\
\text { staircase, } \\
\text { Zone } 2 \\
\text { (context nr. } \\
\text { 1524, 1475) }\end{array}$ & $\begin{array}{l}\text { LH IIIB2 } \\
\text { Late }\end{array}$ & $\begin{array}{l}28 b, \\
38 a\end{array}$ & \\
\hline $23 \mathrm{Ti}$ & M3 & ARG1 & $\begin{array}{l}\text { Cup } \\
\text { FS } 220\end{array}$ & Fine Plain & $\begin{array}{l}\text { rough surfaces, white soft, } \\
\text { dark inclusions (density: } \\
\text { "occasional”) }\end{array}$ & $\begin{array}{l}\text { Western } \\
\text { staircase, } \\
\text { Zone } 2 \\
\text { (context nr. } \\
\text { 1444, 1390, } \\
1513 \text { ) }\end{array}$ & $\begin{array}{l}\text { LH IIIB2 } \\
\text { Late }\end{array}$ & $\begin{array}{l}32 d, \\
36 a, \\
38 b\end{array}$ & \\
\hline $24 \mathrm{Ti}$ & M3 & ARG1 & Kylix & Fine Plain & $\begin{array}{l}\text { rough surface, small and } \\
\text { very rarely big ( }>4 \mathrm{~mm} \text { ) } \\
\text { white soft, dark inclusions } \\
\text { (density: “occasinal”); } \\
\text { silver sparkling dust } \\
\text { size inclusions (density: } \\
\text { "occasional”) }\end{array}$ & $\begin{array}{l}\text { Western } \\
\text { staircase, } \\
\text { Zone } 2 \\
\text { (context nr. } \\
1362 \text { ) }\end{array}$ & $\begin{array}{l}\text { LH IIIB2 } \\
\text { Late }\end{array}$ & $39 c$ & \\
\hline $25 \mathrm{Ti}$ & M3 & ARG1 & $\begin{array}{l}\text { Kylix } \\
\text { FS 258B }\end{array}$ & $\begin{array}{l}\text { Fine } \\
\text { painted }\end{array}$ & cf. JunG 2008, fabric M10 & $\begin{array}{l}\text { Lower } \\
\text { Citadel } \\
\text { LXI 42/80 } \\
\text { XVIa }\end{array}$ & $\begin{array}{l}\text { LH IIIB } \\
\text { Middle }\end{array}$ & $37 c-d$ & $\begin{array}{l}\text { SCHÖNFELD } \\
1988, \text { fig. } \\
5.4\end{array}$ \\
\hline 26Ti & M3 & ARG1 & $\begin{array}{l}\text { Kylix } \\
\text { FS258A }\end{array}$ & $\begin{array}{l}\text { (lustrous } \\
\text { paint) }\end{array}$ & cf. JuNG 2008, fabric M10 & $\begin{array}{l}\text { Lower } \\
\text { Citadel } \\
\text { LXII 42/71 } \\
\text { XIVa }\end{array}$ & $\begin{array}{l}\text { LH IIIB } \\
\text { Middle }\end{array}$ & & $\begin{array}{l}\text { SCHÖNFELD } \\
1988, \text { fig. } \\
11.17\end{array}$ \\
\hline 27Ti & M3 & ARG1 & $\begin{array}{l}\text { Kylix } \\
\text { FS } 257\end{array}$ & $\begin{array}{l}\text { Fine } \\
\text { painted }\end{array}$ & cf. Jung 2008, fabric M13 & $\begin{array}{l}\text { Lower } \\
\text { Citadel } \\
\text { TI LXII } \\
43 / 13 \\
\text { XVIIb } \\
\text { R215 }\end{array}$ & $\begin{array}{l}\text { LH IIIB } \\
\text { Middle }\end{array}$ & & $\begin{array}{l}\text { SCHÖNFELD } \\
1988, \text { fig. } \\
3.19\end{array}$ \\
\hline $28 \mathrm{Ti}$ & M3 & ARG1 & $\begin{array}{l}\text { Stemmed } \\
\text { bowl } \\
\text { FS } 305\end{array}$ & $\begin{array}{l}\text { Fine } \\
\text { painted }\end{array}$ & cf. sample no. 1 & $\begin{array}{l}\text { Lower } \\
\text { Citadel } \\
\text { LXII 43/85 } \\
\text { XVI }\end{array}$ & & & \\
\hline
\end{tabular}


Table 13 Catalogue of the samples examined though macroscopic and X-Ray analysis at Tall Zirā̄a. For description of contexts see JuNG forthcoming.

\begin{tabular}{|c|c|c|c|c|c|c|c|c|c|c|}
\hline $\begin{array}{c}\text { Sample } \\
\text { no. }\end{array}$ & $\begin{array}{c}\text { XRay } \\
\text { sample }\end{array}$ & $\begin{array}{c}\text { Roux } 6 \\
\text { method }\end{array}$ & Chaîne & Shape & $\begin{array}{l}\text { Cate- } \\
\text { gory }\end{array}$ & Fabric code & $\begin{array}{l}\text { Context } \\
\text { (unstrati- } \\
\text { fied) }\end{array}$ & $\begin{array}{l}\text { Chronolo- } \\
\text { gy (based } \\
\text { on typolo- } \\
\text { gy) }\end{array}$ & Figure & $\begin{array}{c}\text { Publi- } \\
\text { cation } \\
\text { reference }\end{array}$ \\
\hline $1 T Z$ & $\begin{array}{c}\text { XRay } \\
\text { sample } \\
1\end{array}$ & 3 (or 4$)$ & ARG1 & $\begin{array}{l}\text { rounded } \\
\text { alabastron, } \\
\text { perhaps } \\
\text { FT } 85\end{array}$ & $\begin{array}{l}\text { Fine } \\
\text { painted }\end{array}$ & $\begin{array}{l}\text { cf. JuNG 2008, fabric } \\
\text { M10 }\end{array}$ & TZ1331-003 & $\begin{array}{l}\text { probably } \\
\text { LH IIIA2 }\end{array}$ & $\begin{array}{l}32 \mathrm{~h}, 33 \\
44.7\end{array}$ & $\begin{array}{l}\text { JunG, in } \\
\text { press, } \\
\text { pl. X.1.17 }\end{array}$ \\
\hline $2 \mathrm{TZ}$ & $\begin{array}{c}\text { XRay } \\
\text { sample } \\
2\end{array}$ & 3 (or 4$)$ & ARG1 & \begin{tabular}{|l|} 
small \\
piriform jar \\
FT 45
\end{tabular} & $\begin{array}{l}\text { Fine } \\
\text { painted }\end{array}$ & $\begin{array}{l}\text { cf. JunG 2008, fabric } \\
\text { M10 (but secondarily } \\
\text { burnt) }\end{array}$ & TZ2874-035 & LH IIIA2 & 44.5 & $\begin{array}{l}\text { JunG, in } \\
\text { press, } \\
\text { pl. X.1.10 }\end{array}$ \\
\hline $4 T Z$ & $\begin{array}{c}\text { XRay } \\
\text { sample } \\
3\end{array}$ & 3 (or 4$)$ & ARG1 & \begin{tabular}{|l|} 
rounded \\
alabastron \\
FT 82 or 84
\end{tabular} & $\begin{array}{l}\text { Fine } \\
\text { painted }\end{array}$ & $\begin{array}{l}\text { cf. JUNG 2008, fabric } \\
\text { M12 }\end{array}$ & TZ3605-019 & LH IIIA1 & $\begin{array}{l}28 \mathrm{e}, \\
35 \mathrm{a}, \\
44.6\end{array}$ & $\begin{array}{l}\text { JunG, in } \\
\text { press, } \\
\text { pl. X.1.18 }\end{array}$ \\
\hline $5 T Z$ & $\begin{array}{c}\text { XRay } \\
\text { sample } \\
4\end{array}$ & 3 (or 4$)$ & ARG1 & $\begin{array}{l}\text { medium- } \\
\text { sized } \\
\text { piriform jar } \\
\text { FT 30/31 }\end{array}$ & $\begin{array}{l}\text { Fine } \\
\text { painted }\end{array}$ & $\begin{array}{l}\text { cf. JuNG 2008, fabric } \\
\text { M10, not only white, } \\
\text { but also gray particles } \\
\text { (density: less than } \\
\text { “occasional”); } \\
\text { Mycenae (NAA) }\end{array}$ & TZ5105-072 & LH IIIA1 & $\begin{array}{l}32 \mathrm{~g}, \\
44.3\end{array}$ & $\begin{array}{l}\text { JunG, in } \\
\text { press, } \\
\text { pl. X.1.9 }\end{array}$ \\
\hline $6 \mathrm{TZ}$ & $\begin{array}{c}\text { XRay } \\
\text { sample } \\
5\end{array}$ & 3 (or 4$)$ & ARG1 & $\begin{array}{l}\text { goblet } \\
\text { FT } 255\end{array}$ & $\begin{array}{l}\text { Fine } \\
\text { painted }\end{array}$ & $\begin{array}{l}\text { for colors of paint cf. } \\
\text { Jung 2008, fabric } \\
\text { M10, color of surface } \\
2.5 Y \text { 7/3 (pale } \\
\text { yellow); color of } \\
\text { break 7.5YR 7/4 } \\
\text { (pink); gray particles } \\
\text { (density: less than } \\
\text { “occasional”); Tiryns } \\
\text { (NAA) }\end{array}$ & TZ5143-016 & LH IIIA1 & 44.1 & $\begin{array}{l}\text { JunG, in } \\
\text { press, } \\
\text { pl. X.1.1 }\end{array}$ \\
\hline 7TZ & $\begin{array}{c}\text { XRay } \\
\text { sample } \\
6\end{array}$ & 3 (or 4$)$ & ARG1 & $\begin{array}{l}\text { medium- } \\
\text { sized } \\
\text { piriform jar } \\
\text { FT 30/31 }\end{array}$ & $\begin{array}{l}\text { Fine } \\
\text { painted }\end{array}$ & $\begin{array}{l}\text { cf. JuNG 2008, fabric } \\
\text { M13,not only white, } \\
\text { but also gray particles } \\
\text { (density: less than } \\
\text { “occasional”) }\end{array}$ & $\begin{array}{l}\text { TZ20018- } \\
025\end{array}$ & LH IIIA1 & $\begin{array}{l}31 \mathrm{~b} \\
34 \mathrm{a}, \\
44.4\end{array}$ & $\begin{array}{l}\text { JunG, in } \\
\text { press, } \\
\text { pl. X.1.7 }\end{array}$ \\
\hline $8 T Z$ & $\begin{array}{c}\text { XRay } \\
\text { sample } \\
7\end{array}$ & 3 (or 4$)$ & ARG1 & $\begin{array}{l}\text { kylix of } \\
\text { LH IIIA1 } \\
\text { type }\end{array}$ & $\begin{array}{l}\text { Fine } \\
\text { painted }\end{array}$ & $\begin{array}{l}\text { cf. JUNG 2008, fabric } \\
\text { M10, but in addition } \\
\text { to white particles also } \\
\text { brown particles } \\
\text { (density: } \\
\text { “occasional”); } \\
\text { Mycenae (NAA) }\end{array}$ & $\begin{array}{l}\text { TZ20586- } \\
001(1-3) \\
\text { TZ 020586- } \\
015\end{array}$ & LH IIIA1 & $\begin{array}{l}29 \mathrm{e}, \\
34 \mathrm{~b}, \\
44.2\end{array}$ & $\begin{array}{l}\text { JunG, in } \\
\text { press, } \\
\text { pl. X.1.2 }\end{array}$ \\
\hline
\end{tabular}



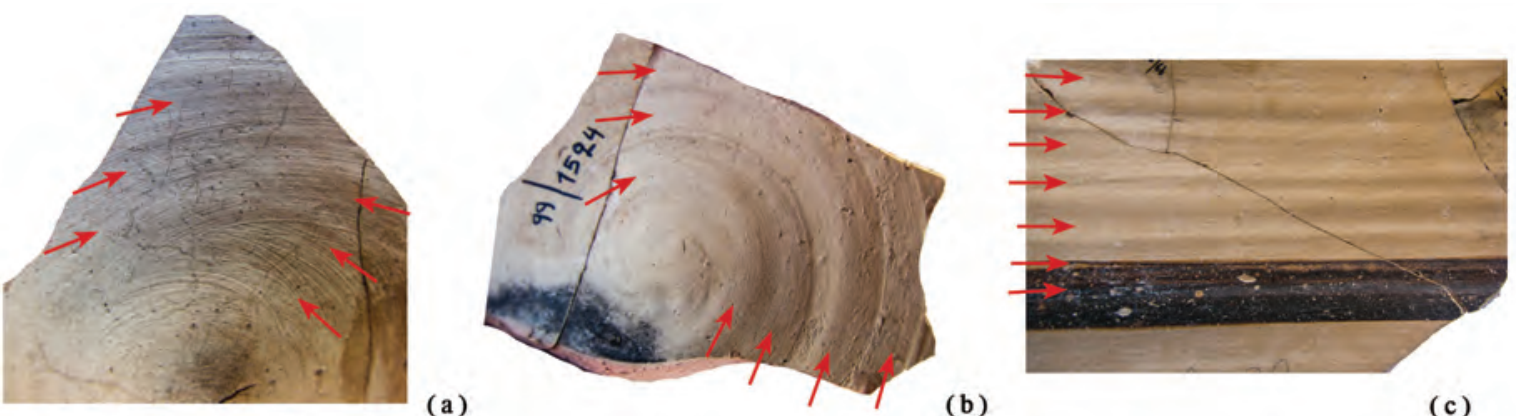

(b)

(c)
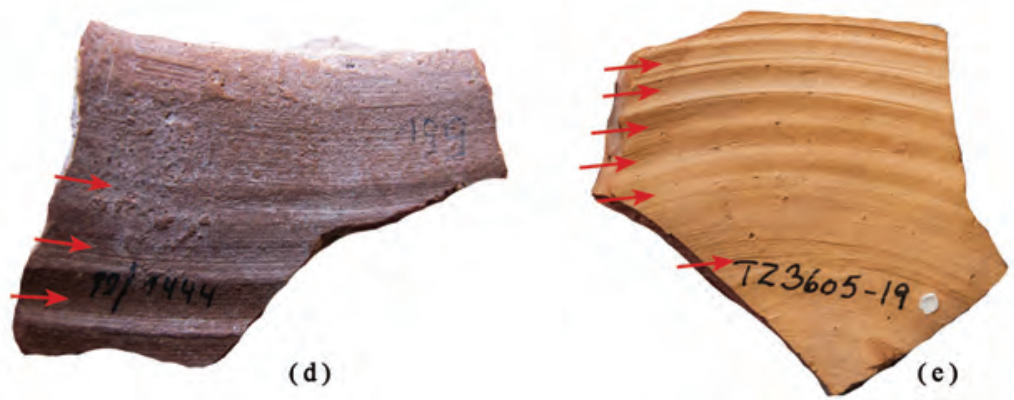

Fig. 28 Tiryns and Tall Zirāca. Examples of concentric parallel undulations in the form of bands on internal/external surfaces: (a) 16Ti; (b) 22Ti; (c) 2Ti; (d) 20Ti; (e) 4TZ (Xray sample 3) (Photos by M. Choleva)

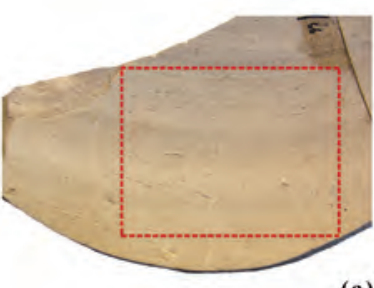

(a)

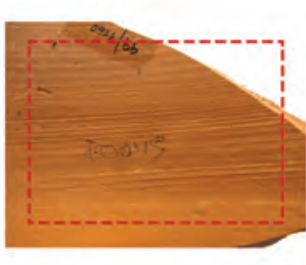

(b)

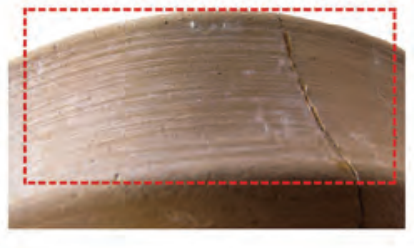

(c)

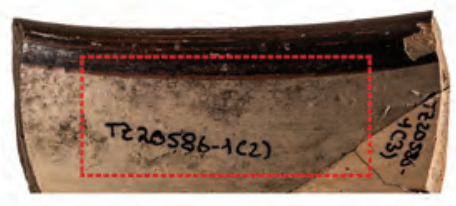

(d)

Fig. 29 Tiryns and Tall Zirāca. Examples of horizontal and rectilinear striations on internal/external surfaces: (a) 10Ti; (b) 5Ti; (c) 14Ti; (d) 8TZ (Xray sample 7) (Photos by M. Choleva)
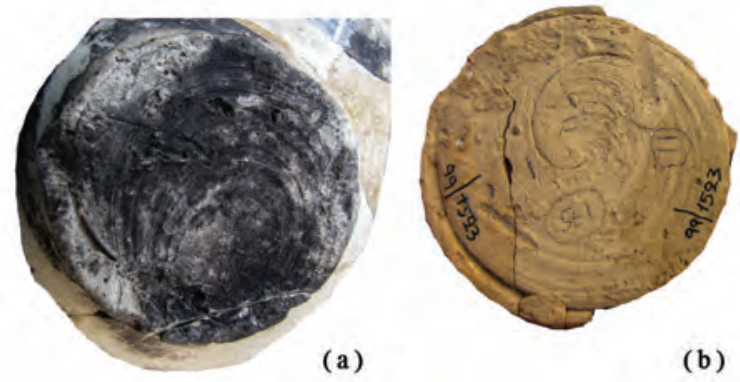

(b)
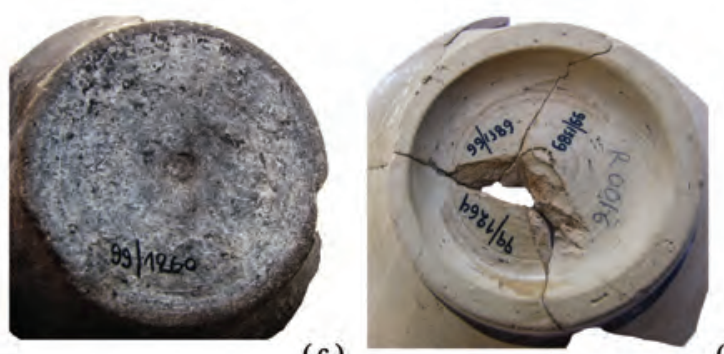

(d)

Fig. 30 Tiryns. Variety of striations underneath the bases: (a) 15Ti; (b) 13Ti; (c) 21Ti; (d) 1Ti (Photos by M. Choleva)

running around internal and external surfaces (Fig. 29) as well as concentric and semi-circular striations underneath the bases are also identified (Fig. 30), whereas compression ripples, known as “torsional ripples" reveal high pressures applied during shaping ${ }^{144}$ (Fig. 31). On the other hand, elongated fissures observed on the breaks, and shapeless 'hollowed' features on the surfaces sug-

144 JefFra 2011, 129-130. 

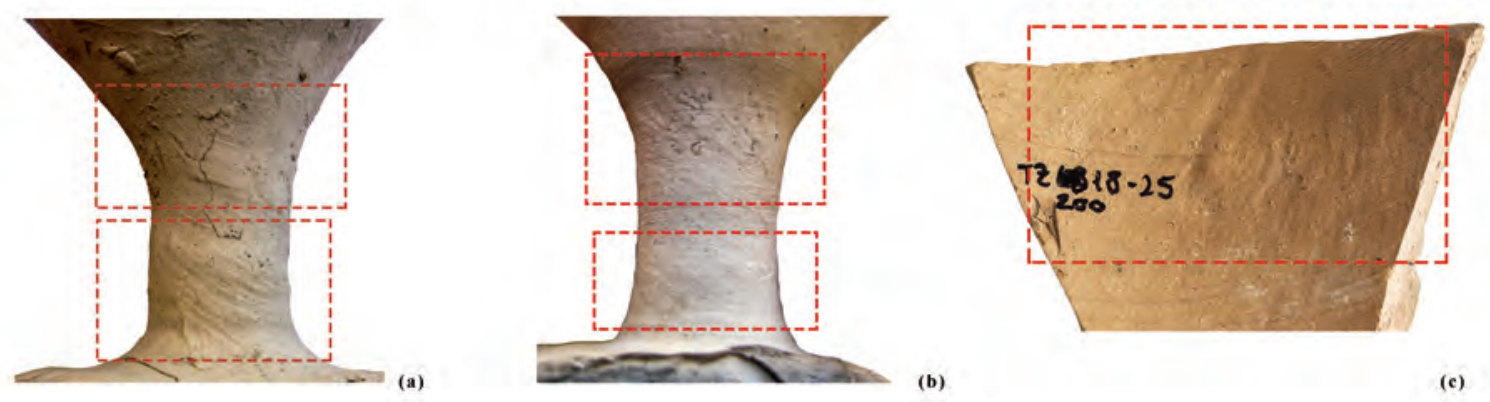

Fig. 31 Tiryns and Tall Zirāca. RKE-derived compression ripples on internal surfaces: (a) 13Ti; (b) 18Ti; (c) 7TZ (Xray sample 6) (Photos by M. Choleva and R. Jung)

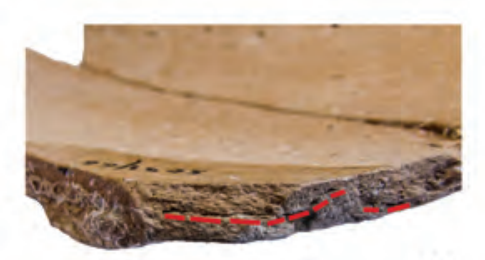

(a)

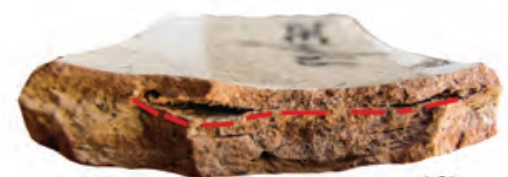

(d)

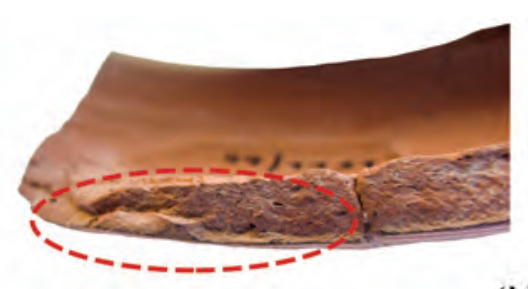

(b)

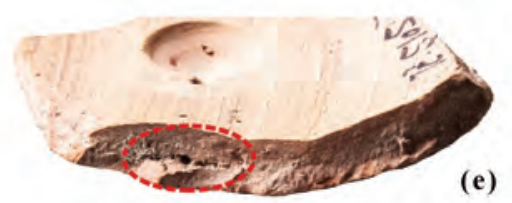

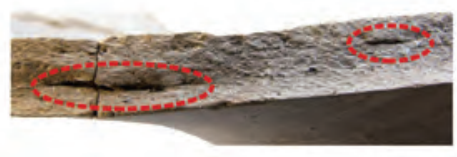

(c)
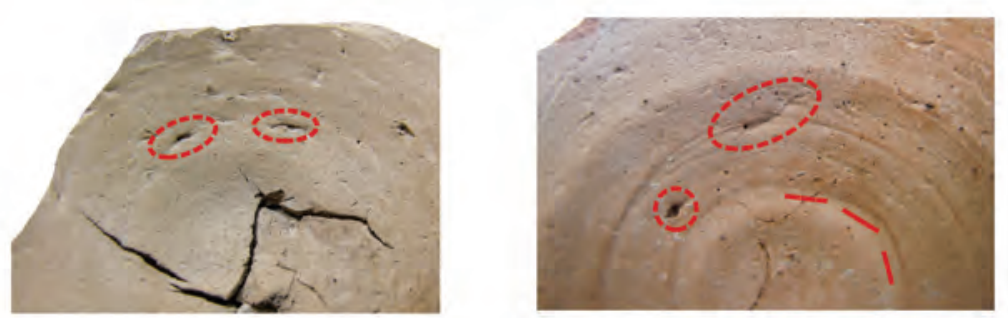

(g)

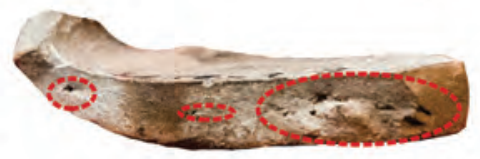

(f)

Fig. 32 Tiryns and Tall Zirāca. Variety of coil seams visible on surfaces and breaks: (a) 1Ti; (b) 5Ti; (c) 8Ti; (d) 23Ti; (e) 5TZ; (f) 1TZ; (g) 18Ti; (h) 13Ti (Photos by M. Choleva)

gest coil seams and thus indicate the presence of coil-built roughouts (Fig. 32). The radiographic analysis of the imported pottery of Tall Zirāca validates the use of the wheel-coiling technique for the Argive wheelmade production. ${ }^{145}$ The clay matrix of the sherds is characterized by an intense diagonal orientation of voids, and sometimes inclusions. Contrary to Ayios Vasileios, there is no evidence for horizontally distributed elongated voids or occasional thinned areas in bodies (Fig. 33). On the other hand, larger long and shapeless voids with sharp to diffuse boundaries are observed indicating coil seams. Interestingly, the voids along coil seams follow, in many cases, the orientation of 'structural' voids: they are elongated and strongly inclined (Fig. 34a-b).

istic for the wheel-coiling technique (LEONARD ET AL. 1993, pls. 2b, 3d, 4d).
The radiographs of three small stirrup jars, which were
found on Rhodes and near Mycenae and are of Argive provenance according to NAA, also show traits character- 


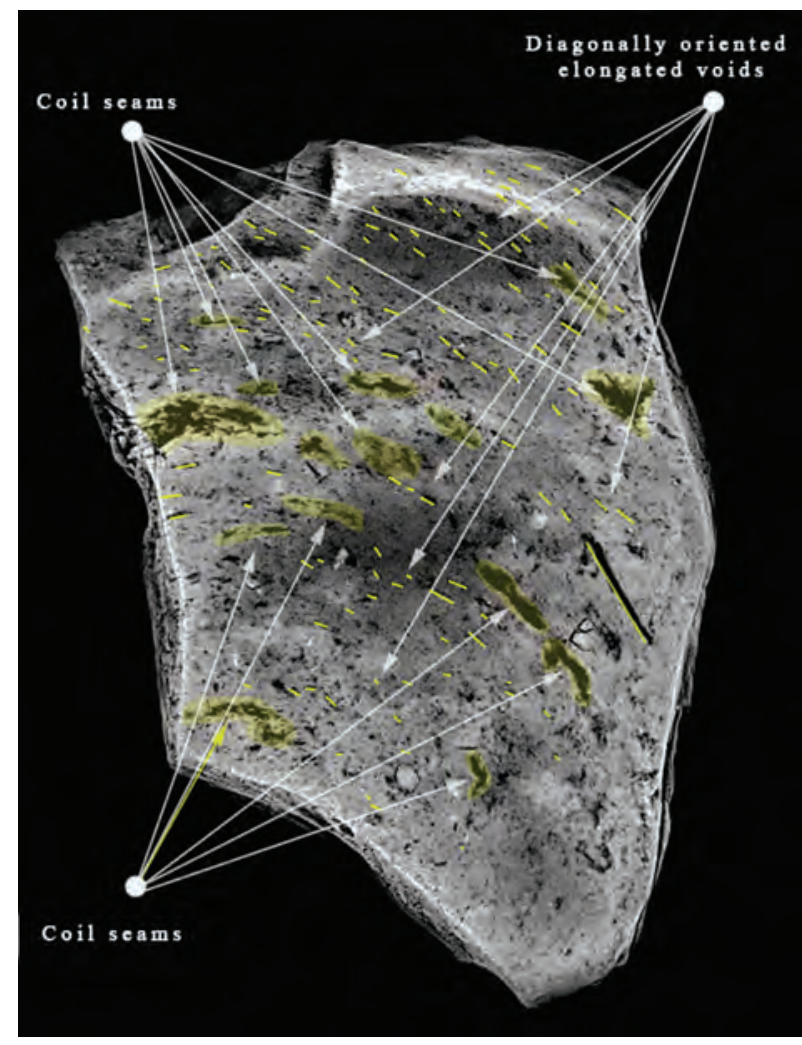

Fig. 33 Tall Zirā̄a. Diagonal orientation of 'structural' voids observed in 1TZ (XRay sample 1) (XRay by G. Stangl, X-ray Service GmbH Austria)

\section{Degrees of RKE exploitation}

The examined pottery produced in the Argolid shares common manufacturing attributes that imply a high degree of RKE exploitation. All the studied material is characterized by a strong wall modification created at least during joining the coils on the potter's wheel. The diagnostic macrofeatures are therefore associated with the wheelcoiling method 3. In the X-radiographs, the prominent diagonal orientation of both 'structural' voids and coil seams reveals microstructures strongly modified by RKE. They suggest the effective and profound deformation of all the components of the ceramic material through continuous pressures with upwards direction during the building up of the walls. Contrary to Ayios Vasileios, the absence of certain areas with horizontally or randomly distributed elongated or flattened voids reveals the transformation of the assembled elements into a "homogeneous" volume and confirms Roux and Courty's observation that the early exploitation of RKE in the forming process of the coil-building can result in more homogenized clay masses. ${ }^{146}$

This total deformation of roughouts observed in the two assemblages of Argive pottery could thus be related to (a) either a greater exploitation of

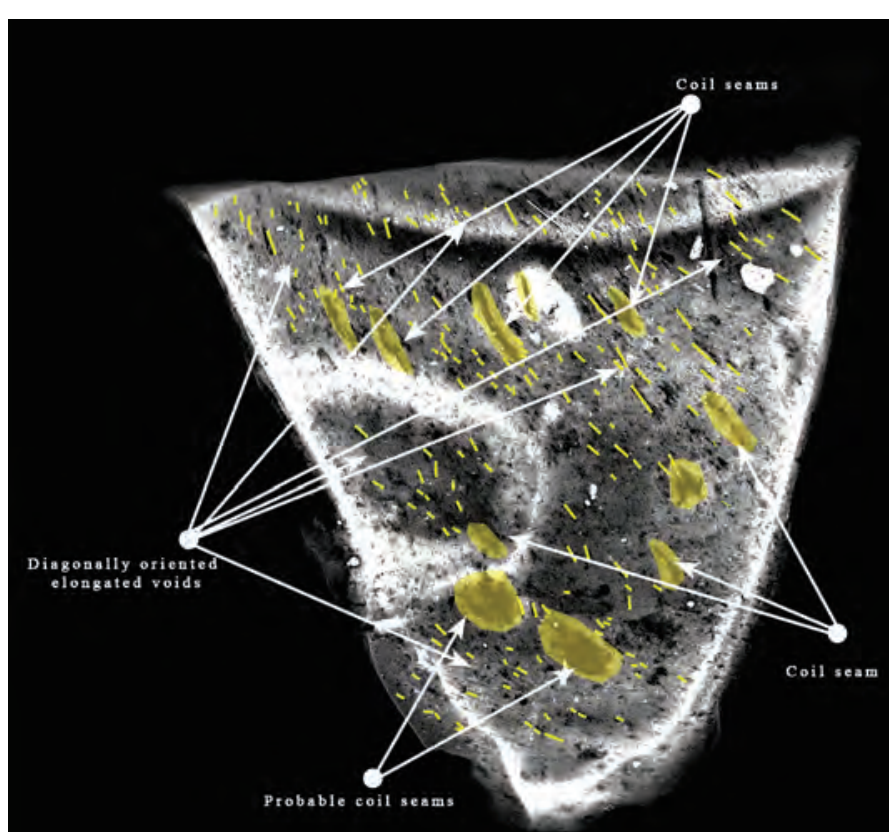

(a)

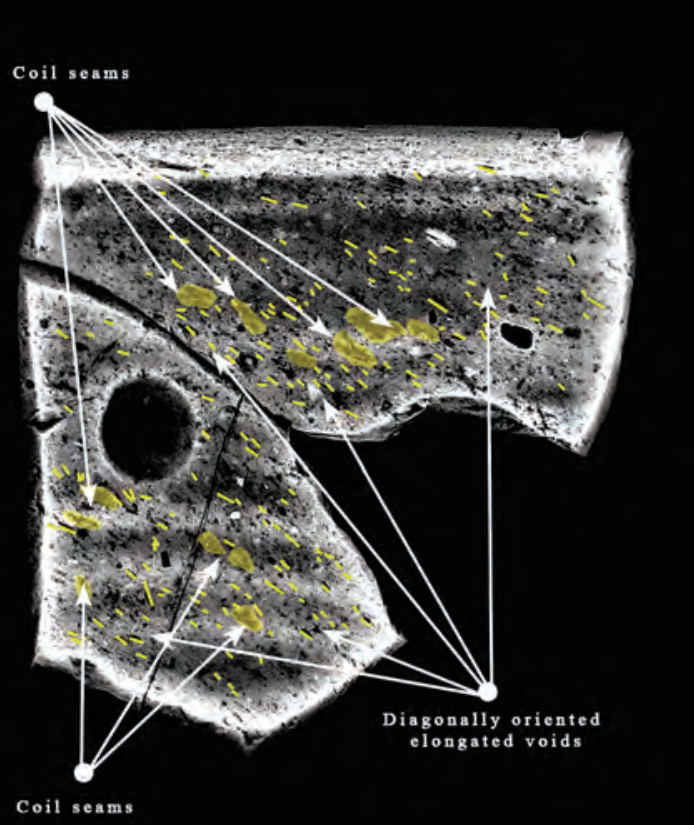

Coil seams

Fig. 34 Tall Zirā̄a. Different types of elongated fissures and voids along coil seams observed in (a) 7TZ (XRay sample 6) and (b) 8TZ (XRay sample 7) (XRay by G. Stangl, X-ray Service GmbH Austria)

146 Roux and Courty 1998, 753-754. 
RKE, that means stronger forces, enhanced stability in the application of continuous pressure, and higher speed during the joining of the coils, and therefore to the usage of the wheel-coiling method 3 ; or (b) to the use of the potter's wheel from the very beginning of the forming operations, i.e. forming the coils on the wheel, and hence to the wheel-coiling method $4 .{ }^{147}$ However, without excluding the second scenario but taken cognizance of the lack of experimental data and the difficulty in discerning macroscopically pots made by method 3 from those made by method 4, we should consider the striking resemblance of the RKE-derived macro-features of the Argive pots to those identified in the pottery of Ayios Vasileios as an indicator for the use of a variant of the wheelcoiling method $3 .{ }^{148}$ In any case, the strongly deformed roughouts of those pots suggest the early use of the potter's wheel in the manufacturing process. It is further important to note that according to the NAA results the variant of method 3 (or method 4) that is characteristic for the Argolid, was practiced both in the north and in the south of the region. ${ }^{149}$

\subsubsection{Identification of chaînes opératoires and craft behaviours}

Despite the heterogeneity of the ceramic material in terms of context and dating and despite the small examined sample, the macroscopic and X-ray analysis shed light on a similar way of using the wheel in the forming process and showed a commonly shared chaîne opératoire, here termed ARG1, behind all the Argive pots. The examined ceramic assemblages of Argive manufacture consist exclusively of pottery made by the wheel-coiling method 3 (or perhaps by method 4), which was used as a primary forming technique (Fig. 35a-b). The pots are composed by coils while the wheel, reaching high speeds and involving constant continuous pressures, is used for joining the different elements, thinning the walls and shaping the roughout. The

147 Roux 2017, 114.

148 Unfortunately, the resolution of the published radiographs of the Argive stirrup jars investigated by LEONARD ET AL. (1993, pls. 2b, 3d, 4d) does not allow a detailed comparison with our data regarding this specific aspect.

149 The chemical pattern MYBE of samples 5TZ and 8TZ points to a manufacture in the region of Mycenae (northern Argolid), while the chemical pattern TIR of sample 6TZ can be assigned to Tiryns in the southern Argolid (Mommsen in: Jung forthcoming). underlying chaîne is therefore founded on the early exploitation of RKE in the forming process and produces a wide spectrum of shapes of different dimensions, sizes and coarseness, which belong to both plain, monochrome and painted wares (bowls, cups, kylikes, krater, closed vessels, alabastra, jars, and cooking pots) (Tabs. 12-13).

Regarding the specific potting practices involved in the operational sequence, it is notable that the few bases of bowls and cups that were examined provide evidence for the use of a small flattened slab (Fig. 36a), on which the coils of the body are attached to build up the walls, whereas few examples are made by coil(s) (Fig. 36b). The kylikes, in turn, seem to be made in the same way as the ones of chaîne LAC 1 from Ayios Vasileios. Their body is built by coils (Fig. 37e-g) which are attached to the upper part of the roughout of the lower part that, in turn, consists of the stem and the disc base (Fig. 37d). Interestingly, most of those disc bases are made by a slab or superposed slabs (Fig. 37a-b). Contrary to Ayios Vasileios, the stems (especially in the plain kylikes) are characterized by torsional ripples which suggest the junction and the shaping of both the stem and the bowl-body on the wheel and hence the bottom-up manufacture of the pots (see Figs. 31a-b, 37b). ${ }^{150}$ Most of them would have been finished upside down on a slowly rotating wheel as the fine concentric striations and the wheelmade dome underneath indicate, in the same way as at Ayios Vasileios (Fig. 37h). However, some others present an exceptional technical attribute and which has not yet been identified among the Lakonian kylikes. The disc bases of certain unpainted kylikes bear underneath semi-circular string marks indicative of their removal from the wheel while rotating, an evidence suggesting, again, the bottom-up wheel-shaping of the vessels (Fig. 38a; see also Fig. 37a). ${ }^{151}$ This technical feature is actually closely related with another shape, the conical cup, regardless of its place of manufacture. ${ }^{152}$ Interestingly enough, when it comes to kylikes,

150 According to the experiment of JEFFRA $(2011,130)$ torsional ripples have the tendency to be specific to the wheelcoiling methods 3 and 4 .

151 Kylix-bases with semi-circular marks are attested at least as early as LH IIIA2 in the NE Peloponnese (THOMAS 2011A, 214 and Fig. 23.257).

152 Conical cups usually have this type of string-cut base wherever they appear, be it in Crete, where they originate, or in the Eastern Aegean or on the Greek mainland. 


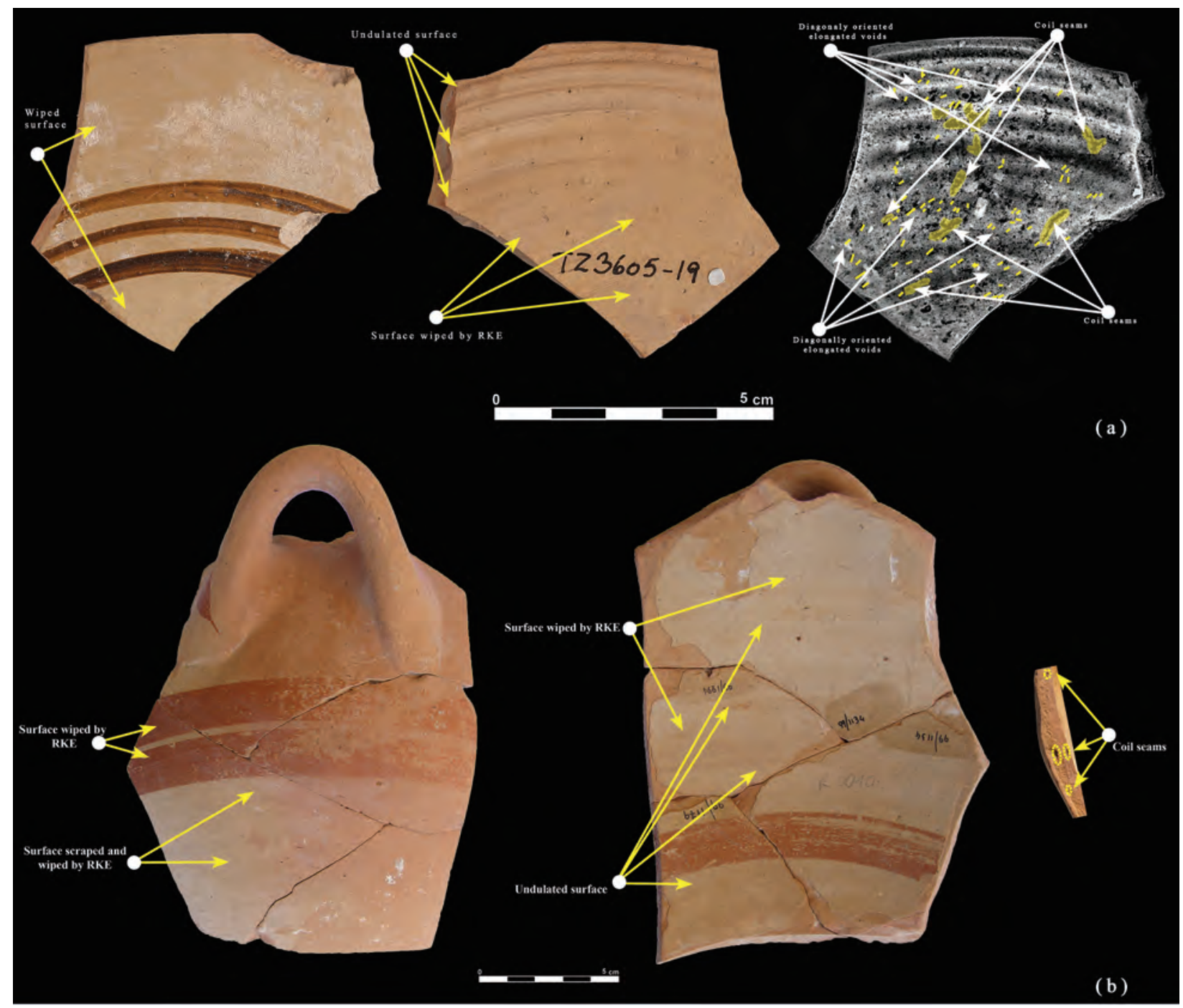

Fig. 35 Tiryns and Tall Zirāca.Examples of the chaîne opératoire ARG1: (a) 4TZ (XRay sample 3); (b) 3Ti (Photos by M. Choleva and R. Jung) (XRay by G. Stangl, X-ray Service GmbH Austria)
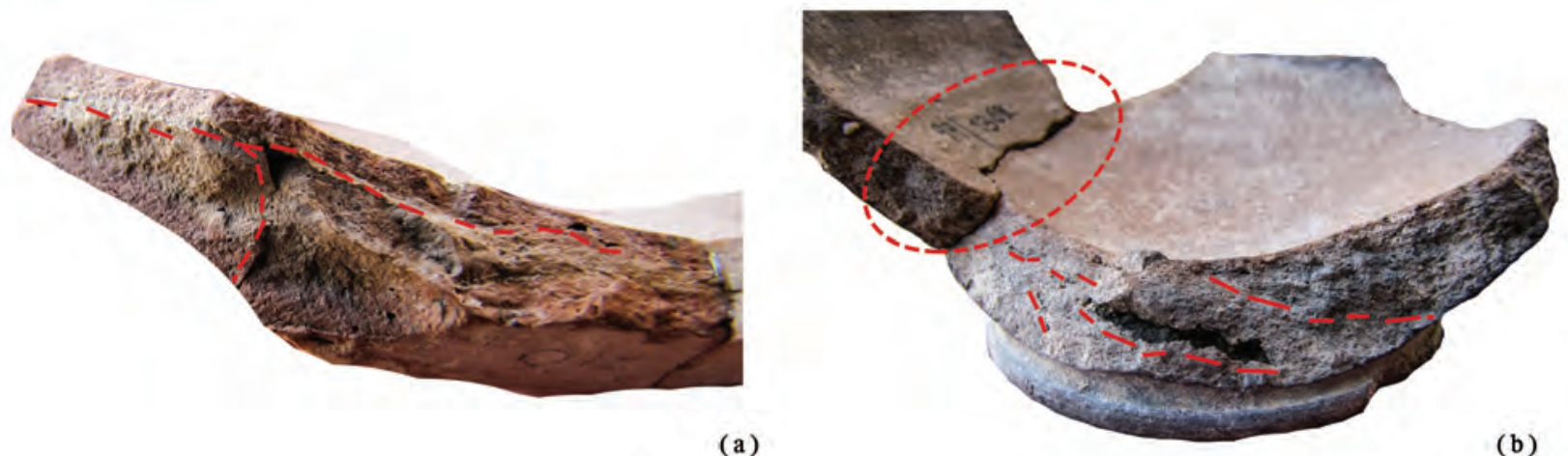

(a)

(b)

Fig. 36 Tiryns. Macro-features indicative of bases made by a slab or coils from Tiryns: (a) 23Ti; (b) 21Ti (Photos by M. Choleva) 


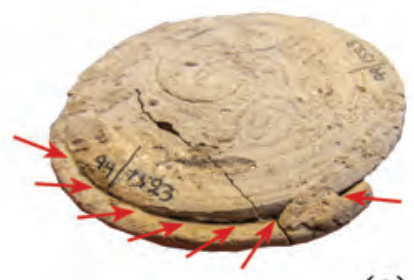

(a)

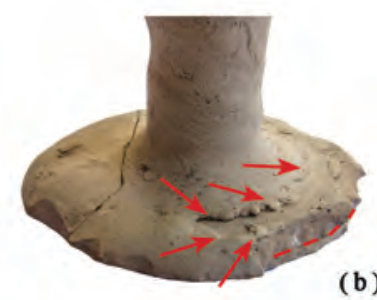

(b)

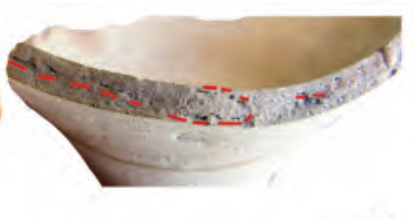

(e)

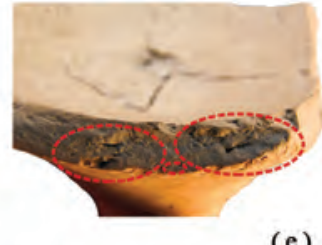

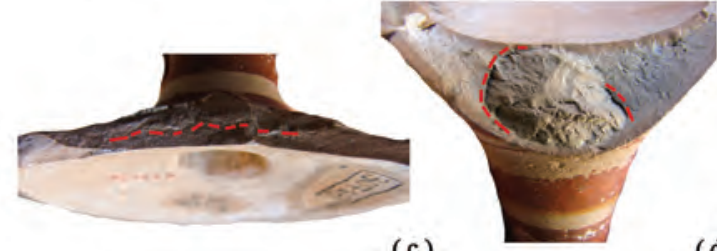

(c)

(d)

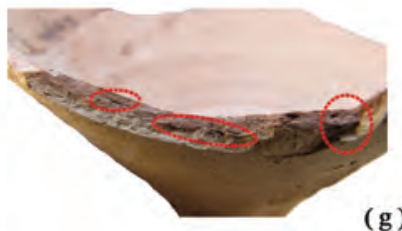

(g)

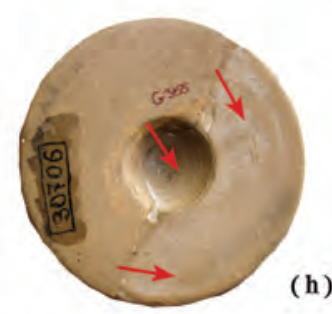

Fig. 37 Tiryns. Macro-features indicative of forming operations involved in kylikes: (a) 13Ti; (b) 13Ti; (c) 25Ti; (d) 25Ti; (e) 18Ti; (f) 16Ti; (g) 13Ti; (h) 16Ti (Photos by M. Choleva)
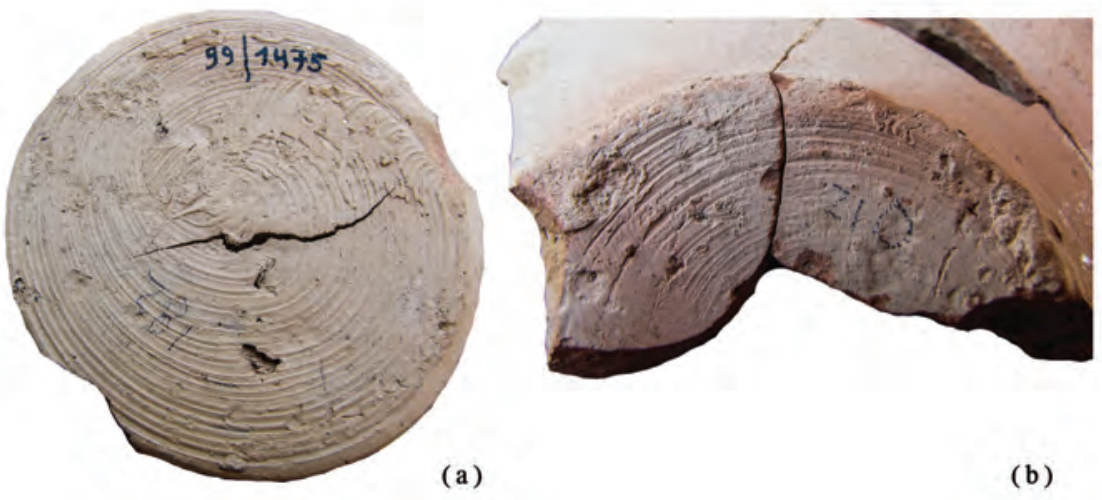

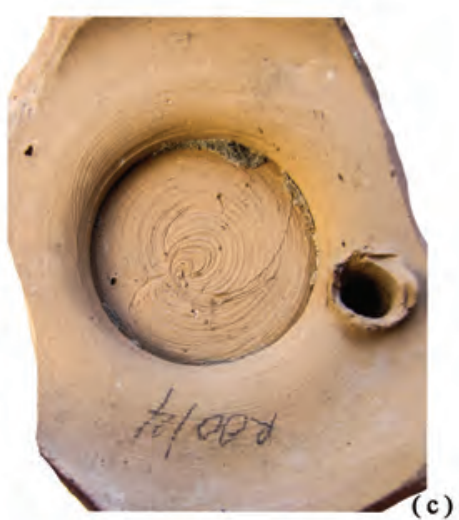

Fig. 38 Tiryns. Examples of string marks from Tiryns: (a) 22Ti; (b) 23Ti; (c) 6Ti (Photos by M. Choleva)

this method of detachment from the wheel concerns mainly one type, i.e. the carinated kylix (FS 267), and was not used in the manufacture of conical or rounded kylikes. ${ }^{153}$ Moreover, it seems to have been a peculiarly Argive practice, since kylikes outside the Argolid and the NE Peloponnese rarely exhibit this feature. ${ }^{154}$ This kind of string marks are also observed underneath unpainted bowls and cups (Fig. 38b) as well as on the interior of a false neck belonging to a small painted stirrup jar and it therefore reveals that

153 See KARDAMAKI FORTHCOMING.

154 But see Catuing 2009, 404; Fig. 175.WE77; 179.WS52; 190. PD140, 143-144 for solid kylix bases with cut marks from LH IIIA2/LH IIIB and LH IIIB/LH IIIC Early deposits at the Menelaion. According to Catling, bases of this type are in the minority. Tномаs 2011B, 301, remarks that kylikes removing pots or different parts of them from a spinning wheel was a common practice for many shapes in the Argolid (Fig. 38c). ${ }^{155}$ As for the surface treatment, most of the pots are wiped and smoothed on the wheel (Fig. 39a-d) whereas the lower parts of some others are scraped by RKE (turning) (Fig. 39e).

The chaîne opératoire ARG1 identified among all the wheelmade pots originating from either northern or southern Argive workshops was enacted by complex gestures requiring demanding

with flat, unfinished bases are frequent in the Argolid. However, they would not have provided good stability on flat surfaces - in contrast to kylikes with domed bases.

155 In Pylos this feature appears on miniature kylikes but also dippers (Hruby 2006, 187, Fig. 6.5; 188) 


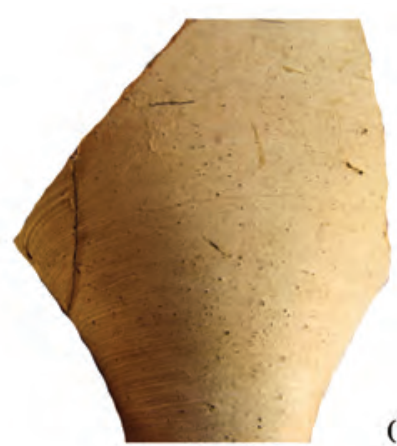

(a)

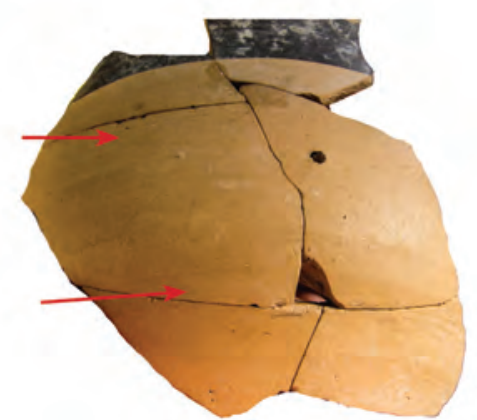

(d)

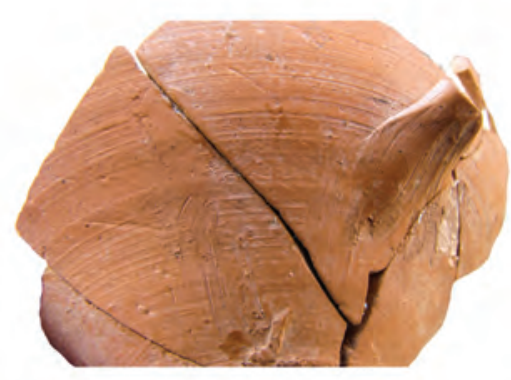

(b)

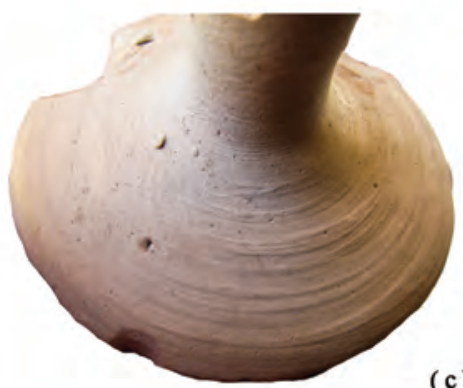

(c)

Fig. 39 Tiryns. Macro-features indicative of RKE finishing operations: (a) 16Ti; (b) 19Ti; (c) 24Ti; (d) 4Ti; (e) 1Ti

(Photos by M. Choleva)

motor and cognitive skills for the mastery of the potter's wheel. From this perspective, the underlying craft behaviour is built upon a highly specialized technical knowledge. Despite the differences in some potting practices (see below), this craft behaviour shares the same knowledge of the wheel as the one identified behind the dominant chaine opératoire at Ayios Vasileios (LAC 1). Interestingly, as in Laconia, this craft behaviour seems to be already in action in LH III A1 as the imported northern and southern Argive pots from Tall Zirăca suggest and was maintained through LH IIIC Early as the presumably northern and southern Argive pots from Tiryns reveal (see Tab. 12).

\section{The Technology of Mycenaean Pottery Production}

\subsection{The spread of the potter's wheel}

To address the issue of when the potter's wheel came to be widely adopted in Mycenaean pottery workshops, we must mainly refer to published data, which are - unfortunately - still rather insufficient. First, the development of wheelmade pot-

\footnotetext{
156 For new stratified material see e. g. HALE 2016.

157 Lólos 1987, 74-95, figs. 83-85, 104-117.
}

tery production on the Greek mainland during the MBA is far from being understood in any detail. ${ }^{156}$ Sufficient quantitative data for assessing the overall percentage - and its change over time - are lacking even for the early Mycenaean phases ( $\mathrm{LH}$ I-IIA). LH I and LH II Mycenaean painted pottery is wheelmade - at least in its majority -, and the same may be true of the LH II plain and/or burnished goblets.

In some regions such as the north-eastern Peloponnese and Messenia, large-scale use of the wheel must have started early. For the destruction deposit of a house at Traghána Voroúlia large quantities of LH I decorated and wheelmade pots are reported, but no precise percentages are available for the different Mycenaean and non-Mycenaean pottery classes. ${ }^{157}$ At Tsoungiza, wheelmade plain pottery was well established already by LH I, but in its majority it still seems to have consisted of handmade vessels. ${ }^{158}$ By LH IIA, both plain and painted Mycenaean pottery was reportedly wheelmade, while only the imported Aeginetan matt painted and cooking pot fabrics were handmade. ${ }^{159}$ At Nichoria, an increase of fine wares, most of which were burnished, took place in LH II and

\footnotetext{
158 RutTER 1993, 72. Some of the medium coarse, pale surfaced sherds are wheelmade.

159 Rutter 1993, 59. 68-72; see also RutTER 2015, 208, table 1
} 


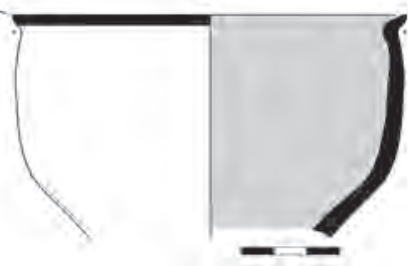

1

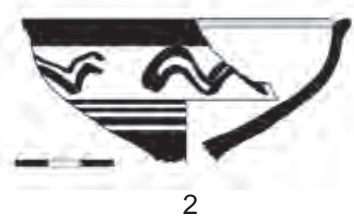

2

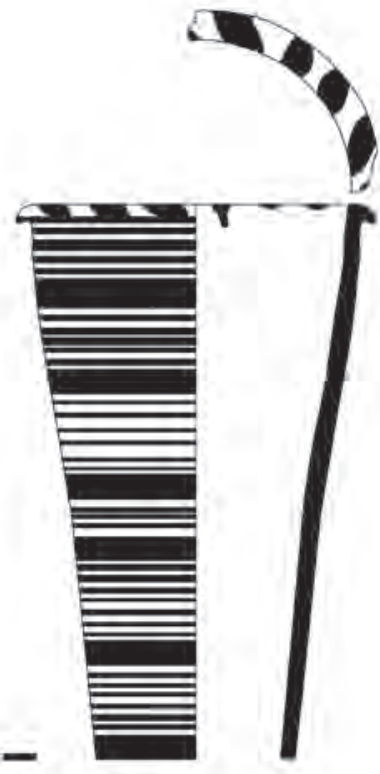

3
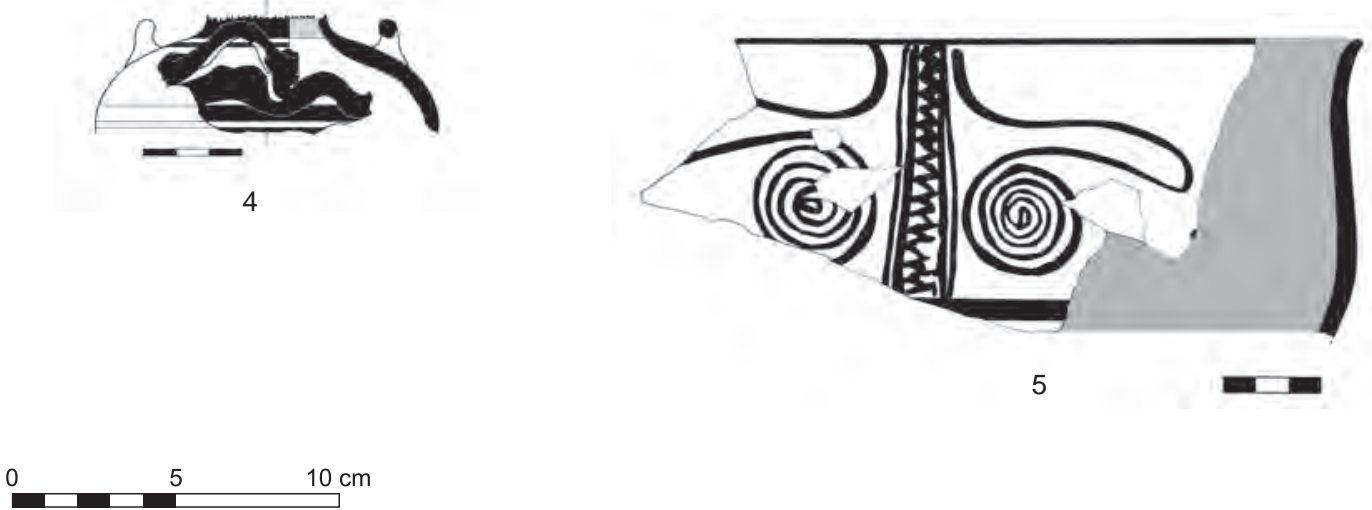

Figure 40

Fig. 40 Ayios Vasileios. Fine painted ware: (01) 270AV (XRay sample 11); (2) 273AV (XRay sample 14); (03) 272 (XRay sample 13); (04) 265AV (XRay sample 6); (5) 202AV. Scale 1:3 (drawings by A. Poelstra Traga)

this was interpreted as wheelthrown production according to the traditional paradigm. ${ }^{160}$ At the same time however, the coarser wares and some other fabrics (such as dull painted and matt painted wares as well as cooking pottery) remained handmade. However, we have to note that the available evidence is still scarce. ${ }^{161}$ At Ayios Vasileios, on the other hand, the majority of the plain wares are still handmade in LH IIA while

160 DiCKINSON 1992, 472-473. 486.

161 ZERNER 2008; DiCKINSON 1992. wheelmade goblets become frequent only from $\mathrm{LH}$ IIB onwards. ${ }^{162}$

From the above it is clear that in some regions and most notably the NE and SW Peloponnese the fine tablewares (whether polished or burnished) were largely wheelmade at the latest from LH IIA or IIB onwards. Thus, the spread of the potters' wheel occurred during the formative phase of the Mycenaean economy, before the establishment of

162 Hachtmann forthcoming. Also, at Ayios Stephanos there is no evidence for wheelmade goblets prior to LH IIB. ZERNER 2008. 

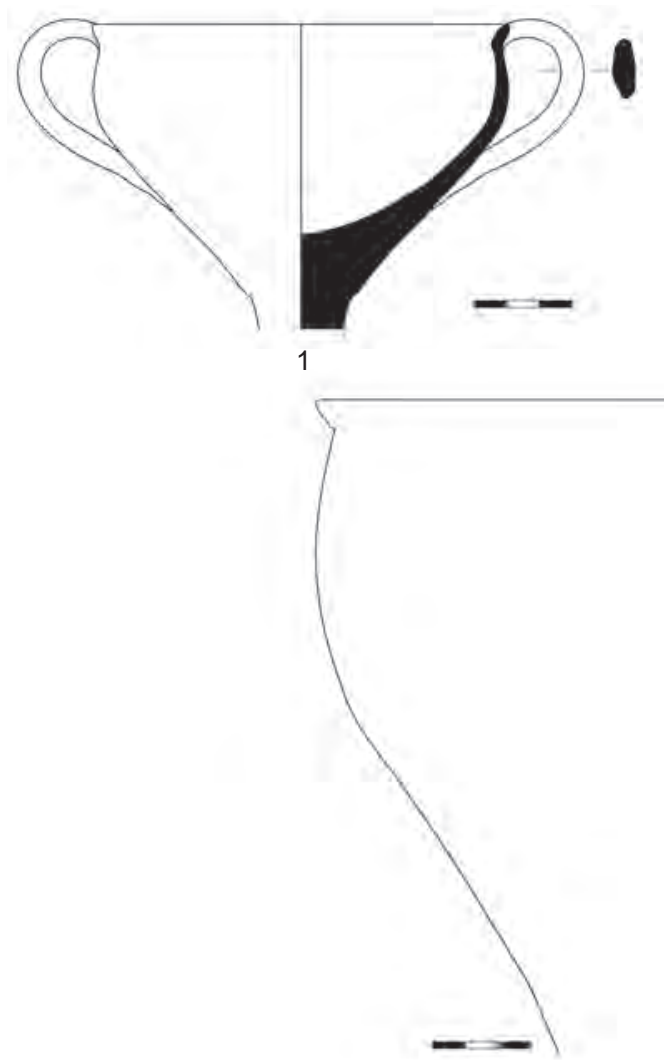
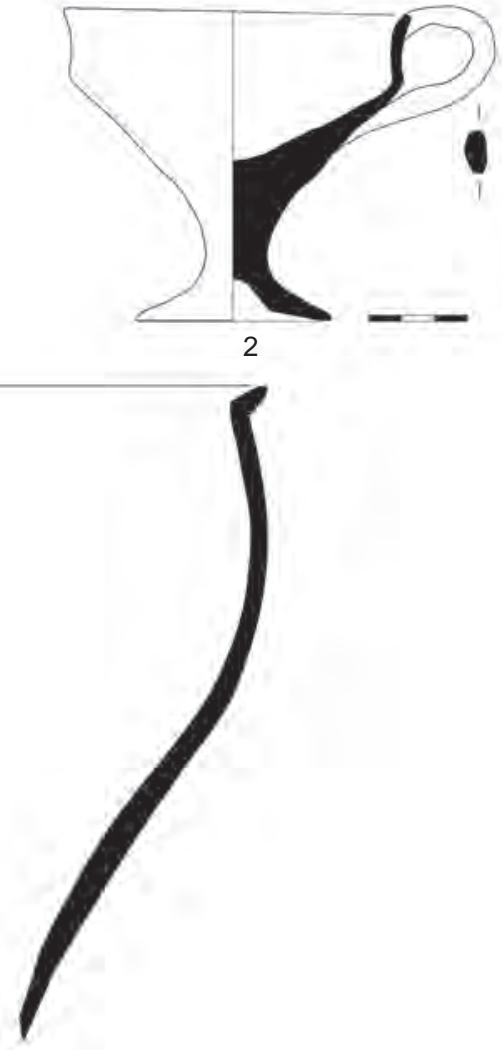

3
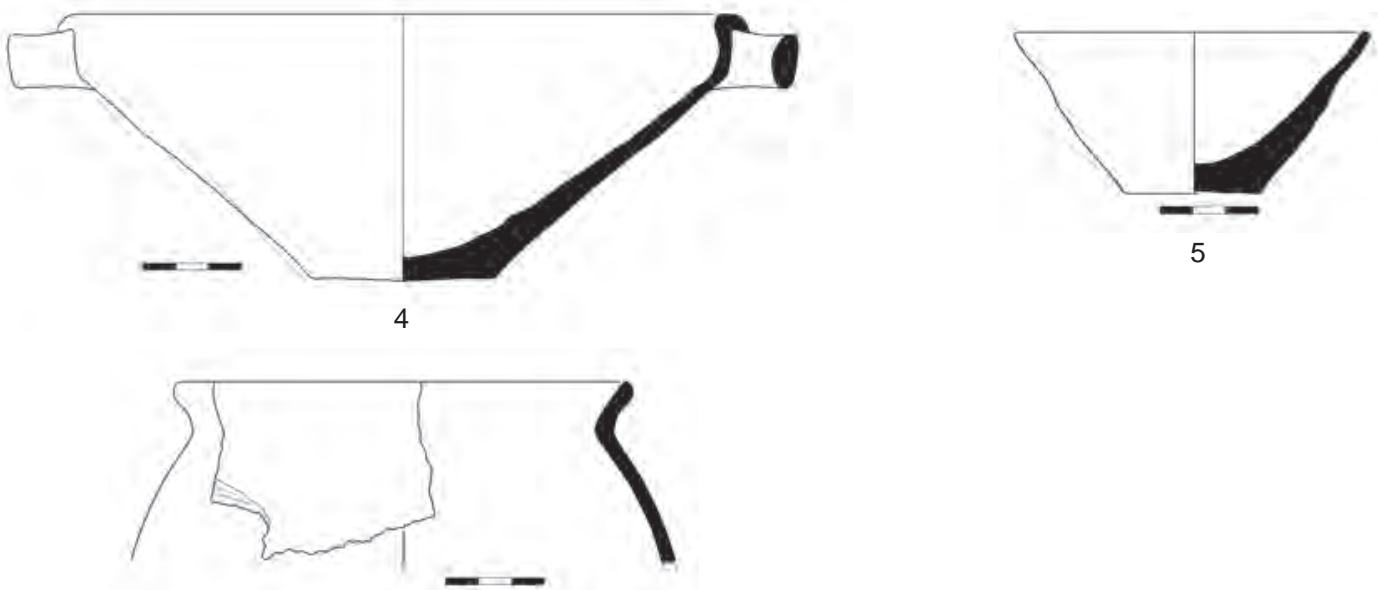

6

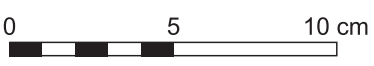

Figure 41

Fig. 41 Ayios Vasileios. Fine plain ware: (01) 197AV; (2) 157AV; (03) 261AV (XRay sample 2); (04) 268AV (XRay sample 9); (5) 264AV (XRay sample 5); (6) 301AV (cooking ware rim, method 3; not included in table 7). Scale 1:3 (drawings by A. Poelstra Traga) 
the palaces and their bureaucracies. Furthermore, the assessment of the different Peloponnesian sites seems to indicate that the Argolid set the standards, since some of the most typical Mycenaean plain shapes seem to appear for the first time in large quantities in the NE Peloponnese. ${ }^{163}$ The adoption of the wheel may have been connected with the growing importance of unpainted fine wares, and this technological change may then have facilitated subsequent real mass production starting in the early palace period (LH IIB/IIIA1).

This is of course not to say that hand-forming techniques went totally out of use after the Early Mycenaean period. During LH IIIA1 the use of the wheel must have increased, but in some regions handmade vessels remained popular. ${ }^{164}$ At Ayios Vasileios, the hand-building technique is also attested for certain closed vessels or cooking pots that continue a MH III tradition. ${ }^{165}$ This is also true for the plain hydrias, jugs and amphoras from the Menelaion. ${ }^{166}$ In some LH IIIA1/LH IIIA2 contexts from Ayios Vasileios these plain handmade jars account for $6 \%$ of the rim sherds but in LH IIIA2 they become rare. ${ }^{167}$ The use of handmade bowls of various shapes is attested in some Mycenaean palaces even up to LH III C Early while the manufacture of pithoi or vats in handforming techniques remained common throughout the Late Bronze Age all over mainland Greece. ${ }^{168}$

\subsection{The way of practicing the potter's wheel}

Our macroscopic and microscopic observations on pots coming from both Laconia and the Argolid demonstrate that both painted and unpainted Mycenaean pottery at least from LH IIB up to LH IIIC Early was made by the wheel-coiling technique. Contrary to the traditional discourse, which used to correlate the mass production of Mycenaean pottery with the throwing of clay lumps, there is no sign for wheelthrown vessels among the material we studied. Wheelmade pots including a

163 THOMAS 2011b.

164 Kaza-Papageorgiou and Kardamaki 2018. The colour slipped and burnished/unburnished pottery wares from Kontopigado include both handmade and wheel-shaped closed vessels. The open shapes are probably wheelmade. At Athens the Acropolis burnished ware (LH IIB/LH IIIA1) is reportedly wheelmade (MounTJoy 1981, 51).

165 KARDAMAKi 2017.

166 CAtling 2009, Figs. 87.ET8; 88.ET10; 102.ET179. Also, the majority of the button-based cooking jugs are handmade wide spectrum of wares and shapes from painted and monochrome to plain vessels and from bowls and conical cups to kylikes and alabastra were mostly manufactured by coils fashioned with the help of RKE. This probably allows the hypothesis that at least by the beginning of the palatial period and until 1200 BCE (LH IIIA1-IIIB Final) a common basic manufacturing technology fusing coiling with the potter's wheel was widespread.

The prevailing character of the wheel-coiling technique among the material of Ayios Vasileios and the presence of the same technique within the pottery found at Tiryns and Tall Zirā'a suggest the existence of common contexts of apprenticeship ensuring the learning and the transmission of specific technical knowledge in production over time and space. This inference is also supported by the identification of one common and dominant way of mastering the potter's wheel both in Laconia and in the Argolid. The most frequently applied forming technique at Ayios Vasileios is method 3 of Roux's classification system. The occurrence of the same method among the examined material produced in the northern and the southern Argolid should not be considered as 'accidental'. This method determines two similar chaînes opératoires in Laconia (LAC 1) and in the Argolid (ARG 1), which share after all the same "technical logic": the mastery and exploitation of the potter's wheel in the forming process from the early manipulation of the roughout stage onwards. Method 3 appears to have been also in Crete the most frequent way of practicing the wheel and by LM IA it dominated the technological spectrum of both small and medium to large vessels. ${ }^{169}$ It seems that we can observe the same phenomenon also in the subsequent Mycenaean pottery production.

In this regard, one should note that according to the experimental data collected by Roux and Courty and enriched by Jeffra, wheel-coiling method 3 seems to be the most difficult way of exploiting RKE within coiling. It presupposes

(CAtling 2009, 423-424; CAtling 2009, Fig. 101.ET165: in situ, on floor of Mansion 1). See Lis 2017.

167 In a small LH IIIA2 Early refuse deposit $4.3 \%$ of all diagnostic features and $1.8 \%$ of all rims are from handmade closed vessels (Kardamaki 2017, 88, Tab. 3). Also, in the Meneleaion the handmade traditions seem to cease during LH IIIA2 (CATLING 2009).

168 Lis 2016, 499 and Fig. 6.

169 JEFFRA 2013, 38-43. 


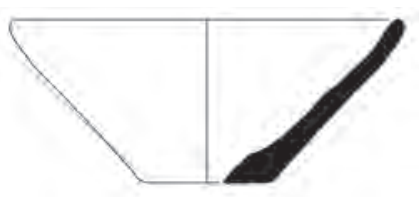

1
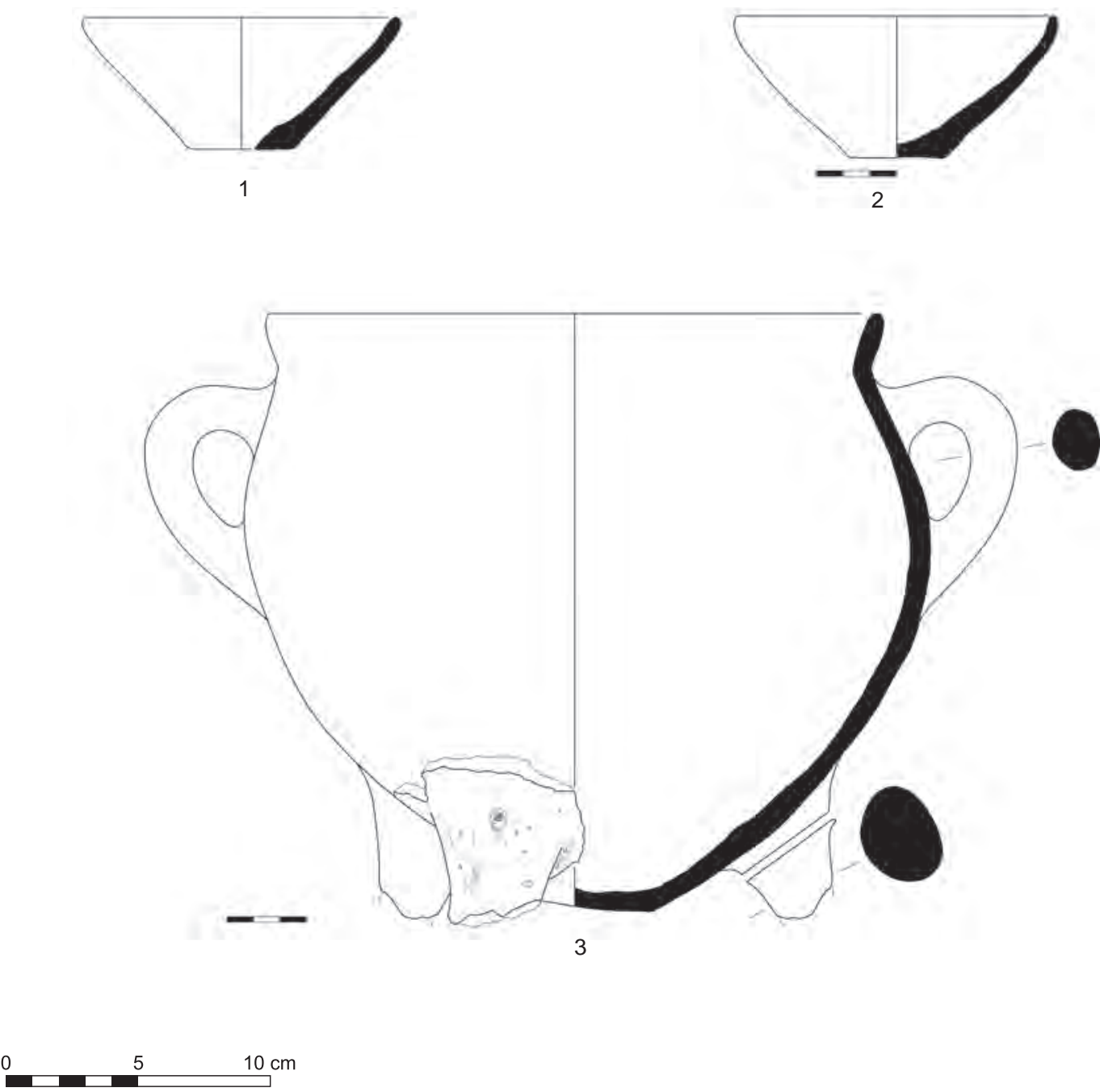

Figure 42

Fig. 42 Ayios Vasileios. Fine plain (1-2) and cooking ware (3): (01) 267AV (XRay sample 8); (2) 175AV; (03) 276 (XRay sample 18). Scale 1:3 (drawings by A. Poelstra Traga)

highly skilled potters and also appears to be the most efficient in terms of time requirements. ${ }^{170}$ This observation, when integrated with the discussion of intensification of Mycenaean pottery production, could contribute to a better understanding of the adoption and spread of this wheel-coiling method in the Peloponnese.

Our study supports the idea that a shared craft behaviour is characteristic of pottery production in Laconia and in the Argolid. This craft behaviour is founded on motor and cognitive skills of high technical specialization implying the adoption of complex gestures mediated by RKE. Its origins go back at least to LH IIB when the first goblets of

170 Roux and Courty 1998, 750, Tab. 2; see also Roux 2017, 114. The time and manner of execution of a forming technique is subject to so many variables that simplistic corre-
Ayios Vasileios were made by the wheel-coiling method 3 and continued throughout LH IIIA into LH IIIC Early, when the same method was still in use in both Laconia and the Argolid. From this perspective, the products of the identified chaines opératoires LAC 1 and ARG 1 can be considered as the manifestation of a well-established standardized and widespread technical knowledge specific to potting communities, the members of which were trained in a common technological tradition that originated from similar models of learning. ${ }^{171}$ This allows us to infer the existence of socio-economic structures (a) enabling the local/ regional development of networks of apprentice-

lations between archaeological record and replication experiments should be treated with caution.

171 Cf. Roux and Brill 2002. 


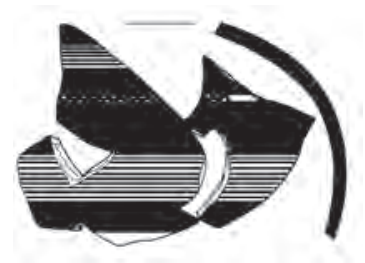

1

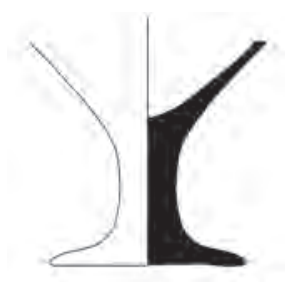

3
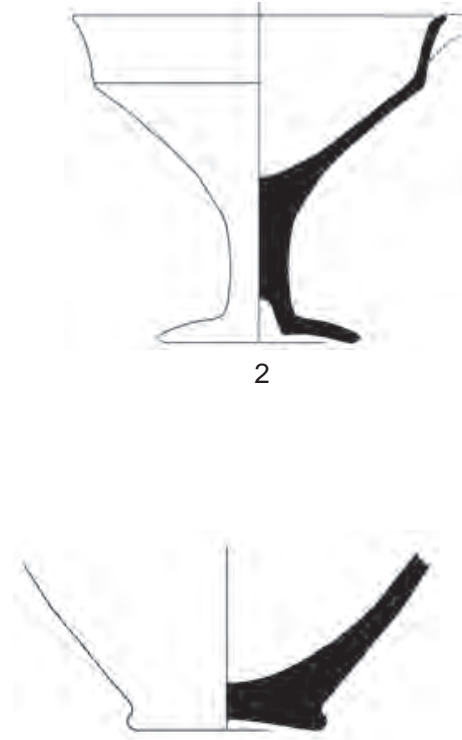

4

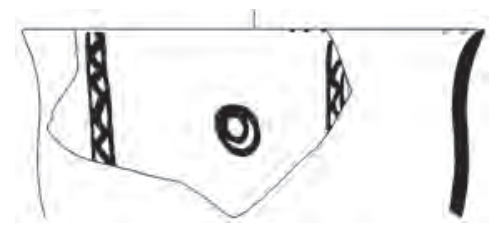

5

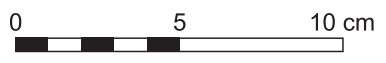

Figure 43

Fig. 43 Tiryns. Fine painted (1, 5), plain (2-3) and cooking (4) ware: (01) 9Ti; (2) Ti18; (03) Ti22; (04) Ti21; (5) Ti11. Scale 1:3 (drawings: 1 by R. Tsembera and $2-5$ by E. Kardamaki)

ship that would ensure the long period of learning and the transmission of a specific know-how and (b) resulting in the training of specialist potters who would adopt a distinct set of potting habits for producing a well-defined range of morpho-stylistic types.

\subsection{Standardization and variability in local potting practices}

Our technological study sheds light on phenomena of technological variability as well as of standardization at the local and inter-community levels. Especially the extended analysis of the pottery from Ayios Vasileios provided an excellent example that allowed us to explore the wheel-based potting practices in the micro-scale of pottery production and to reconstruct the local modalities of appropriation of the relevant manufacturing tech- nology. As mentioned above, pottery production at Ayios Vasileios is mainly articulated around the chaîne opératoire LAC 1 enacted by the wheelcoiling method 3. Interestingly, this chaîne is associated with a wide spectrum of fine table-ware shapes and encompasses, without distinction, both painted, plain and monochrome vessels whereas it produces some cooking pots too (see Tab. 6). This homogeneous assemblage in terms of wheel mastery suggests the same craft behaviour behind pots with different 'function' in consumption habits. It is this standardized craft behaviour that accounts for the presence of standardized products in terms of the specific technological choices involved. On the one hand, the ways of applying the wheel-coiling method 3 appear similar among the different shapes. The coils are joined on the wheel with probably fluctuating speeds or by non-constant continuous pressures, as is suggested by the 

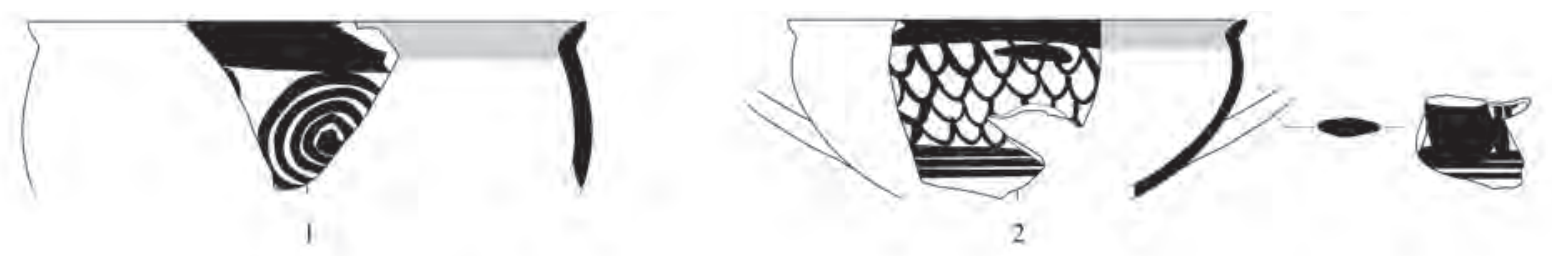

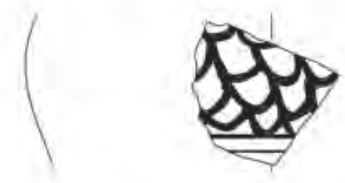

3

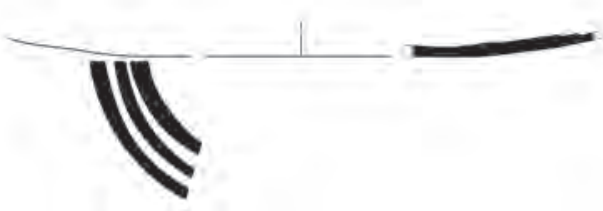

6
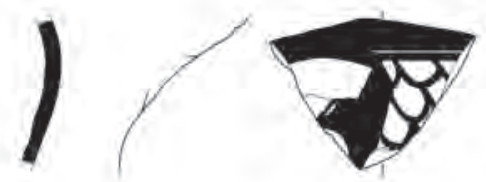

4
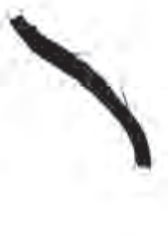
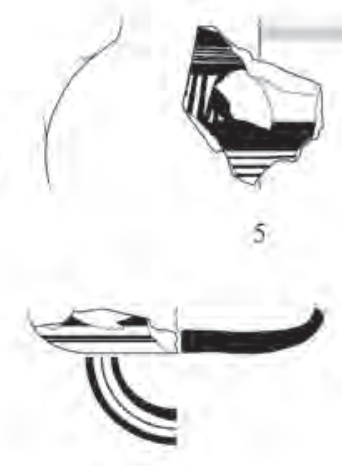

7

Fig. 44 Tall Zirāca. Fine painted ware: (01) 6TZ (XRay sample 5); (2) 8TZ (XRay sample 7); (03) 5TZ (XRay sample 4); (04) 7TZ (XRay sample 6); (5) 2TZ (XRay sample 2); (6) 4TZ (XRay sample 3); (7) 1TZ (XRay sample 1).

Scale 1:3 (drawings by R. Jung)

systematic presence of clusters of horizontally aligned voids over microstructures strongly deformed by RKE. On the other hand, operations such as wiping the surfaces with the help of RKE and detaching the vessels when the wheel is still rotating are the most frequent potting practices in the manufacture of many shapes. The homogeneity of gestural movements and of operational sequences identified in the fashioning of the abundant kylikes and conical cups is also suggestive of common practices spread over the production. They reveal the 'boundaries' of a prevailing potting community at Ayios Vasileios that undertakes the main production of wheelmade pots through the adoption and the maintenance of a wellembedded wheel-based technological tradition.

However, indicators of technological variability are also present among the products of the chaîne LAC 1. Our study has shown that a small portion of the pots made by the wheel-coiling method 3 incorporate different potting practices especially in the formation of the bases (e.g. flattened slabs, coils) and in finishing operations (scraping the surfaces on the wheel and shaping the bases when the pots stands upside-down, RKE wiping and detachment of vessels while rotating). This internal diversity reveals the idiosyncratic character of the involved craft behaviours and probably suggests different production entities belonging to the same wider technological tradition.

The most prominent example of technological variability in the material examined is, however, the observed deviation from the standardized craft behaviours of wheel-coiling method 3. This deviation is expressed through the presence of the chaîne opératoire LAC 2, which stands at the margins of the dominant chaîne LAC 1. LAC 2 implies a different degree of RKE mastery and involves the application of specific motor skills, divergent to those involved in LAC 1 . The occasional use of chaîne LAC 2 and hence of the wheel-coiling method 1 in the manufacture of table-ware shapes that are, in parallel, massively produced by the method 3 underlines a kind of differentiation in craft behaviours associated with the production of wheelmade pots. This differentiation concerns exclusively the way of mastering the potter's wheel and hence the degree of specialization of the learned gestures. The restricted and non-systematic presence of the chaîne LAC 2 - identified in only 25 among 169 wheelmade vessels and fragments - suggests an elementary and less-demanding mastery of the potter's wheel that could point to the existence of a marginal potting community. If we acknowledge that different motor and cognitive skills are representative of potters coming 
from differentiated learning environments and thus from different milieus of apprenticeship, ${ }^{172}$ then we should consider the coexistence of chaînes LAC 1 and LAC 2 as evidence for two potting communities. The latter seem to practice the wheel in a different way but participate in the same context of production serving the same consumption demands. If this is true, the potters of the chaîne LAC 2 would be in contact with the potters of the chaîne LAC 1 , sharing with them not only the knowledge of the potter's wheel but also the same intentions in production. This allows us to consider the two underlying communities as being inter-connected through certain relations (e. g. relations through apprenticeship? coexistence of experts with other production units?).

The existence of different potting communities in central Laconia is best demonstrated on the example of the cooking pottery (but also other local wares such as the gritty hydrias). ${ }^{173}$ It is worth mentioning that up to LH IIIA1/LH IIIA2 almost half of the cooking pottery consumed at Ayios Vasileios belongs to handmade cooking jugs with narrow button bases, the latter continuing from the $\mathrm{MH}$ period. ${ }^{174}$ Next to these, a small assemblage of cooking pots is produced on the potter's wheel, with different wheel-coiling methods. On the one hand, the extremely marginal chaîne LAC 3 encompasses a single locally made cooking tripod that is related to Kytheran and Cretan pottery traditions (see Fig. 26) ${ }^{175}$. This chaîne differs from both the chaines LAC 1 and LAC 2 in terms of RKE mastery: it implicates the use of a rotary device (or even a simple turntable) only to regularize the preform of a pot, previously made by a hand-forming technique (variant of wheel-coiling method 1), and reveals a very low degree of technical specialisation in RKE gestures. The discrete and unique character of the pottery produced through this way in LAC 3 indicated a differentiated craft behaviour, which is largely founded on hand-building forming practices. On the other hand, cooking pots were also produced by the wheel-coiling method 3: a small group of rims and one base belonging to cooking pottery has been made with LAC 1 (see Tab. 6; Figs. 1f and 15c). These vessels show the same fabric as the tripod of LAC 3 (like 276AV/ XRAY sample 18) but as they often come from the upper part of the vessel, it is not possible to say

\footnotetext{
$172 \quad$ See note 36.

173 See also Lis 2017 for the Menelaion.

174 KardamaKi 2017, Fig. 6,95; 7,114-115.
}

whether they come from tripods or from flat based cooking jugs. In light of this, the salient divergences of the chaîne LAC 3 from chaîne LAC 1 and LAC 2 in both morpho-stylistic and technical terms allows us the hypothesis that a distinct production unit trained in a different wheel-based technological tradition is in action and is engaged in particular tasks in the production of cooking pottery.

Overall, the different aspects of technological variability within the pottery production at or around Ayios Vasileios, which in other respects present standardized technical features, may relate to multiple factors. These may have been local ways of organizing the learning of the potter's wheel and the networks of apprenticeship, random production, but also other economic factors suggesting the involvement of more than one specialist with different manufacturing habits. Moreover, the diversity in both the typology and the manufacture of pottery, which involves both wheel- and hand-forming methods, may possibly indicate a division in the organization of production where several potting communities, originating from different contexts of apprenticeship, coexist for producing different kind of pottery and serving different consumption habits.

\subsection{Regional differences}

The study of the selected assemblage from Tiryns and Tall Zirā'a has shown that the potters producing at least a portion of the wheelmade pots in the Argolid participated in the same technological tradition as the dominant potting community at Ayios Vasileios did. Both originated from comparable contexts of apprenticeship. The prevailing use of the wheel-coiling method 3 as well as the associated potting practices involved in the manufacturing process of the Argive pots (chaîne ARG 1) are features which resemble those of the predominant Laconian craft behaviour. They thus suggest the spread of a standardized craft behaviour and hence the transmission of a well-defined way of producing pottery in the potting communities that worked in these different parts of the Peloponnese.

However, there are some differences between the two studied regions that point to local characteristics in the organization of production and the ways of appropriating the potter's wheel:

\footnotetext{
175 The examination of manufacturing techniques among imported classes of pottery from Kythera and Crete will be presented in a separate study.
} 
(a) Both at Ayios Vasileios and Tiryns the chaîne of method 3 (ARG 1, LAC 1) encompasses, apart from fine table wares, also cooking wares. This means that the early exploitation of RKE in the forming process - implying a highly specialized know-how - is extended over a wider range of morpho-stylistic types. This could be evidence that specialist potters mastering the wheel in the Argolid produced not one, but many different pottery classes $.^{176} \mathrm{How}-$ ever, contrary to Tiryns, at Ayios Vasileios part of the cooking assemblage was made with a variant of wheel-method 1 (cooking tripod of LAC 3) suggesting a different potting community in Laconia trained in a differentiated technological tradition.

(b) Whereas at Ayios Vasileios, we have so far identified a common way of finalizing the kylikes, this is not the case in the Argolid, where two different coexisting finishing operations have been recognized among the finds from Tiryns: (i) shaping a dome underneath the disc base when the pots stand upside-down on the wheel, as in the case of Ayios Vasileios, and (ii) removing the pot while rotating with a string, as in the case of conical cups from Ayios Vasileios and elsewhere. The coexistence of two different potting practices reflects divergent habits in manufacture. ${ }^{177}$ This variability possibly implies the labor of potters possessing the same expertise in the mastery of the wheel, but who differed in certain manufacturing habits. Interestingly kylikes involving the finishing operation ii become rare in the early postpalatial period.

(c) Finally, the most salient difference between the Argive and Laconian wheelmade pottery is an invisible manufacturing feature, which has been identified only in the X-Ray images of pots that are macroscopically identical in terms of technical traces. Contrary to the finds from Ayios Vasileios, the northern and southern Argive pots found at Tall Zirā'a are characterized by highly homogenized roughouts (mean-

176 See Gilstrap ET AL. 2016 for Athens. The petrographic analyses on pottery of various wares from Kontopigado and other Attic and Saronic sites suggested the existence of a workshop that manipulated variously the same clay sources for the production of different wares from bath tubs to cooking pots and fine wares.

177 At Ayios Vasileios, the only vessel shape showing this technique is the conical cup. It never occurs on kylikes. ing the total absence of horizontal voids and presence only of diagonal ones), which probably resulted from the effective impact of RKE during the joining of the coils. However, those highly homogenized roughouts might also be the effect of using the wheel-coiling method 4 . Although it is difficult to assess the exact reasons of this technical differentiation at the present stage of our research, the fact that this crucial feature is omnipresent among the examined Argive material, allows us to trace out a distinct community of potters. Especially if these potters applied the wheel-coiling method $4-\mathrm{a}$ method requiring a wheel reaching higher speeds to be effective,$-{ }^{178}$ then we should consider that another way of exploiting RKE, that means a different technical knowledge of mastering the wheel, was in use.

\section{Conclusions}

As a result of our study we can confirm that the degree of typological homogeneity characteristic for the majority of Mycenaean ceramics - at least regarding plain and painted fine wares - is matched by an inter-regionally shared technological knowledge in its manufacture on the potter's wheel. More specifically, we were able to prove the prevailing use of wheel-coiling method 3 (according to Roux's classificatory system) at least in those workshops, which in Laconia and in the Argolid worked for the palaces from LH IIIA1 until the end of the palace period. In addition, the LH IIIC Early vessels from Tiryns demonstrate that this technological knowledge did not get lost with the breakdown of the Mycenaean palace economy. To establish that the underlying networks of common apprenticeship started to function in Laconia already in LH IIA, as has been suggested for the NE Peloponnese, more research is necessary. ${ }^{179}$ Regarding Ayios Vasileios - and probably central Laconia - wheelmade Mycenaean pottery (plain and painted) in LH IIA represents only a small fraction of the overall production.

\footnotetext{
178 Roux 2017, 114.

179 For wheel made burnished and light coloured goblets in LH I and LH IIA at Korakou and elsewhere in the NE Peloponnese as well as in eastern Attica see DiETz 1980; MarAn 1992, 130-131. In LH I Korakou most of the pottery seems to be handmade (Davis 1979, 238). For the Argolid and Tsoungiza in Nemea respectively see DiETz 1991 and RutTER 2015.
} 
Although further investigation is needed, our studies at Ayios Vasileios shows that the fading of entirely handmade table wares took place in central Laconia gradually between LH IIA and LH IIIA2. Until LH IIA, the MH III-style gritty handmade pottery continued but its production was restricted mainly to specific closed shapes after LH IIA. ${ }^{180}$ From LH IIB onwards pottery production underwent a major change when pottery assemblages at Ayios Vasileios began to consist largely of standard wheelmade fine pottery, indicating the formation of distinct communities of potters, specialised in the potter's wheel and reaching a high level of expertise.

We were able to show that parallel to the mastery of the wheel-coiling method 3 , other wheelbased techniques - more specifically method 1 according to Roux - were in use in specific regions in Greece. They were applied in the manufacture of certain vessel classes such as kylikes and conical cups as well as cooking pots even in the palace centers themselves, thus pointing to the existence of various potting communities learning and mastering the potter's wheel in a different way. ${ }^{181}$

Finally, we were able to show that not even the palatial workshops of the Argolid, in which mass production for Aegean and overseas export was developed and the labor organization of which must have been the most advanced in Mycenaean Greece, ${ }^{182}$ practiced the wheel-throwing technique. However, these workshops did possibly develop (or at least apply) a variant of wheel-coiling method 3 - if not method 4 -, which on present knowledge was not available to the workshops at Ayios Vasileios. ${ }^{183}$ The adoption and dominance of this specific technique in the Argive workshops may have been related to a specialized potters' community working for the palace(s) of Mycenae (and Tiryns). This technique may then have enabled those workshops to achieve the quantitatively quite remarkable output of painted fine wares of con-

180 KardamaKi 2017, 101-102 for gritty hand-made hydrias and jugs. CAtLing 2009 and Lis 2017 for the LH IIB/LH IIIA1 “water pots” from the Menelaion.

${ }^{181}$ Furthermore, hand-built pottery also continued to be in use in certain regions, which, however, is not our concern in this paper.

${ }^{182}$ Although we do not know the Argive workshops themselves, their products allow certain indirect inferences about the quantitative and qualitative level their production had reached in comparison to palatial workshops in other stantly high quality that found so many consumers in the Aegean and all around the eastern Mediterranean. In other words, the way in which these potters mastered their means of production was especially suited to the needs of the palace economy in the $14^{\text {th }}$ and $13^{\text {th }}$ centuries BCE. While in the palatial mode of production, the wheel-coiling technique of method 3 was in general use for producing painted and unpainted fine and cooking wares at least in the Peloponnese, its advanced Argive variety (method 4?) might theoretically have offered certain advantages for making pottery export one of the most recognizable features of the Mycenaean economy. Future research will show whether or not this remarkable geographical coincidence of specialized production for export and specific wheel-coiling method is an example of cause and effect. In this respect it will be interesting to investigate if the method identified in the Argolid was also practiced in other Greek regions. Whatever the answer, it becomes clear that the use of the potter's wheel in the Mycenaean world appears to be a complex technological phenomenon involving different potting communities that participated in the social organization of palatial pottery production.

\section{Acknowledgements}

The authors would like to thank Adamantia Vasilogamvrou for allowing us to study and publish the material from Ayios Vasileios. We are grateful to the Ephoreia of Laconia and especially Maria Tsouli and Afroditi Maltezou for their help and support throughout our study. We are grateful to the anonymous reviewers who helped us to improve our paper with their fruitful comments. The study was conducted in the framework of the Austrian Science Fund (FWF) project "Studies on the new Mycenaean Palace of Ayios Vasileios in Laconia” (P28023-G25).

Greek regions. Only the Argive potter's workshops produced large quantities of painted pots for export; the share of pattern-painted pottery they produced was higher than in other regions; they were the workplaces of more painting schools specialized in pictorial pottery than was the case in the regions of other LH IIIA2 - IIIB Middle palaces.

183 The inter-regional picture might change, when more pots from the northwestern Peloponnese will have been investigated for instance. 


\section{Bibliography}

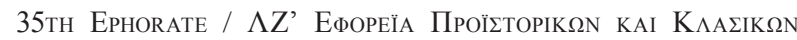
APXAIOTHT $\Omega$ N

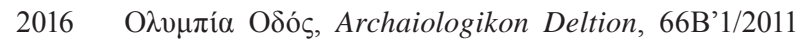
(2016) 424-453.

Abell, N. and Hilditch, J.

2016 Adoption and Adaptation in Pottery Production Practices: Investigating Cycladic Community Interactions through the Ceramic Record of the Second Millennium BCE, in: Gorogianni et al. 2016a, 155-171.

ÅKerströM, Å.

1987 Berbati 2. The Pictorial Pottery, Acta Instituti Atheniensis Regni Sueciae, Series in $4^{\circ}$, 36.2, Stockholm.

Amiran, R and Shenhav, D.

1984 Experiment with ancient potter's wheel, in: P.M. Rice (ed.), Pots and potters, current approaches in ceramic archaeology, UCLA, Institute of Archaeology, Monograph 24, Los Angeles, 107-112.

Arnold, J and Bourriau, J.

1993 An introduction to ancient Egyptian pottery, Mainz am Rhein.

Badre, L., Boileau, M.-C. and Jung, R.

2005 The Provenance of Aegean- and Syrian-type Pottery Found at Tell Kazel (Syria), Ägypten und Levante 15, $15-47$.

BALDI, J. and Roux, V.

2016 The Innovation of the Potter's Wheel: a Comparative Perspective between Mesopotamia and the Southern Levant», Levant 48/3, 236-253.

BERG, I.

2008 Breaking the Mould: Challenging the Past through Pottery. Prehistoric Ceramics Research Group: Occasional Paper 6, BAR-International Series 1861, Oxford.

2009 X-Radiography of Knossian Bronze Age Vessels: Assessing our Knowledge of Primary Forming Techniques. Annual of the British School at Athens 104 (2009), 137-173.

2011 Exploring the chaîne opératoire of ceramics through X-radiography, in: Scarcella, S. (ed.), Archaeological Ceramics: A Review of Current Research, Oxford, 57-63.

2013 The Potter's Wheel in Mycenaean Greece: A Reassessment, in: G. Graziadio, R. Guglielmino, V.

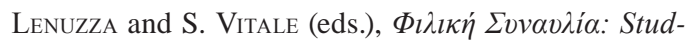
ies in Mediterranean Archaeology for Mario Benzi, British Archaeological Reports International. British Series, Oxford, 113-121.

2015 Potting Skill and Learning Networks in Bronze Age Crete, in: W. Gauss, G. Klebinder-Gauss and C. von RüDEn (eds.), The Transmission of Technical Knowl- edge in the Production of Ancient Mediterranean Pottery. Proceedings of the International Conference at the Austrian Archaeological Institute at Athens, 23 ${ }^{\text {rd }}$ $25^{\text {th }}$ November 2012, Österreichisches Archäologisches Institut Sonderschriften 54, Vienna, 17-34.

Berg, I. and Ambers, J.

2011 Identifying forming techniques in Knossian Bronze Age pottery: the potential of $\mathrm{X}$ radiography, in: $\mathrm{M}$.

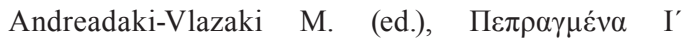

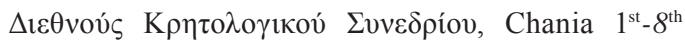
October 2006, Chania, 367-380.

Blegen, C.W.

1921 Korakou. A Prehistoric Settlement near Corinth, Boston, New York.

Boulotis, Chr., Kardamaki, E. and Boloti, T.

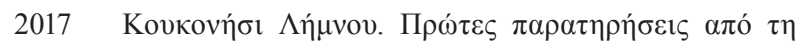

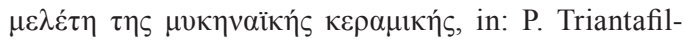

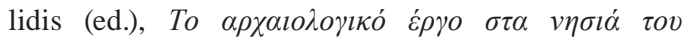
Alyaiov. Proceedings of International workshop held at Rhodes, 27. November - 1. December 2013, Mytilini 2017, 45-62.

Brill, B.

2002 L'apprentissage de gestes techniques : ordre de contraintes et variations culturelles, in : B. BRIL and V. Roux (eds.), Le geste technique. Réflexions méthodologiques et anthropologiques, Revue d'Anthropologie des connaissances, Technologies/ Idéologies/ Pratiques vol. 14.2, Ramonville SaintAgne, 113-150.

Broodbank, C. and Kiriatzi, E.

2007 The First 'Minoans' of Kythera Revisited: Technology, Demography, and Landscape in the Prepalatial Aegean, American Journal of Archaeology 111/2 (2007), 241-274.

CAlOI, I.

2011 Le innovazioni technologiche nella Messarà: Dal wheel-fashioning al wheel-throwing, in: F. CARINCI,

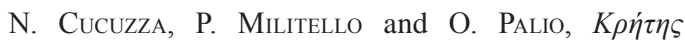
Mivwíos, Studi di Archeologia Cretese 10, Padova, 87-102

CARr, C

1990 Advances in ceramic radiography and analysis: applications and potentials, Journal of Archaeological Science 17 (1990), 13-34.

Catling, H.W.

2009 Sparta: Menelaion I. The Bronze Age, The British School at Athens Supplementary Volume 45, London.

Chatzi-Vallianou, D.

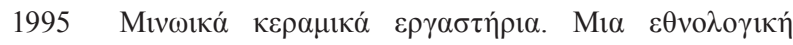

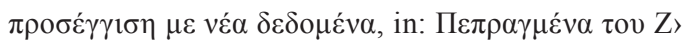

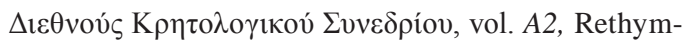
no, 1035-1060. 
2017 The Late Minoan IIIB Pottery of the Gouves Potters' Quarter and Workshops, in: CH. Langohr (ed.), How Long is a Century? Late Minoan IIIB Pottery - Relative Chronology and Regional Differences, Aegis 12, Louvain-la-Neuve, 103-152.

Choleva, $\mathrm{M}$.

2012 The First Wheel-made Pottery at Lerna. Wheelthrown or Wheel-fashioned? Hesperia 81/3 (2012), 343-381.

2015 L'apparition et la diffusion du tour de potier dans le monde égéen, PhD Dissertation, Paris I Panthéon Sorbonne, Paris.

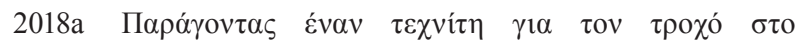

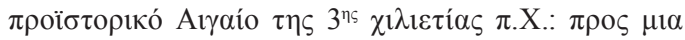

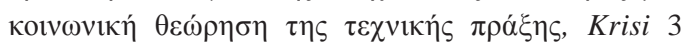
(2018), 53-94.

2018b Craft behaviours during a period of transformations. The introduction and adoption of the potter's wheel in central Greece during Early Bronze Age, in: I. CALOI and C. LANGOHR (eds.) Technology in Crisis. Technological changes in ceramic production during periods of trouble, Louvain-la-Neuve: Presses Universitaires de Louvain: $45-74$.

2020a L'histoire d'un savoir-faire. La transmission du tour de potier et l'émergence de nouvelles traditions technologiques dans le monde égéen pendant $3^{\text {e }}$ millénaire, Annales de la Fondation Fyssen 114: 192-234.

2020b Travelling with the potter's wheel in the Early Bronze Age Aegean, The Annual of the British School at Athens (doi:10.1017/S0068245420000064): 1-46.

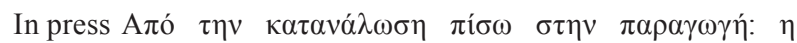

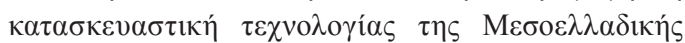

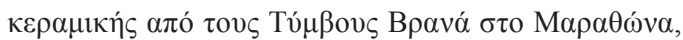
in: M. Pantelidou M., A. -Touchais Philippa, G. Tou-

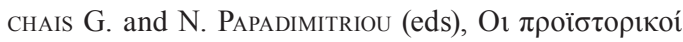

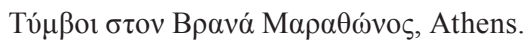

Courty, M-A. and Roux, V.

1995 Identification of wheel throwing on the basis of ceramic surface features and microfabrics, Journal of Archaeological Science 25 (1995), 17-50.

DAvIS, J. L.

1979 Late Helladic I Pottery from Korakou, Hesperia 48 (1979), 234-263.

Davis, J. L. and Lewis, H. B.

1985 Mechanization of Pottery Production: A Case Study from the Cycladic Islands, in: A. B. KNAPP and T. Stech (eds.), Prehistoric Production and Exchange: The Aegean and Eastern Mediterranean, University of California at Los Angeles, Institute of Archaeology, Monograph 25, 79-92.
Demakopoulou K., Divari-Valakou N., Maran J., Mommsen H., Prillwitz S. and Walber G.

2017 Clay paste characterization and provenance determination of Middle and Late Helladic vessels from Midea, Opuscula 10 (2017), 7-49.

Dickinson, O.

1992 Part I: The Late Helladic I and II pottery, in: W.A. McDonald and N.C. Wilkie (eds.), Excavations at Nichoria in Southwest Greece. Vol. 2, The Bronze Age Occupation, Minneapolis, 495-521.

2014 Late Helladic I Revisited: The Kytheran Connection, in: D. NAKAssis, J. Gulizio and S.A. James (eds.), KERA-ME-JA. Studies Presented to Cynthia W. Shelmerdine, Philadelphia, 3-15.

Dietz, S.

1980 Asine II. Results of the Excavations East of the Acropolis, 1970-1974. Fasc. 2. The Middle Helladic Cemetery, the Middle Helladic and Early Mycenaean Deposits. ActaAth 24:2, Stockholm.

1991 The Argolid at the Transition to the Mycenaean Age. Studies in the Chronology and Cultural Development in the Shaft Grave Period, Copenhagen.

Dobres, M.A and Horfmann, C.R.

1994 Social agency and the dynamics of prehistoric technology, Journal of Archaeological Method and Theory 1/3 (1994), 211-258.

DOHERTY, S.

2012 The origins and use of the potter's wheel in Ancient Egypt, PhD Dissertation, Cardiff University, Cardiff.

Eder, B. and Jung, R.

2015 >Unus pro omnibus, omnes pro uno Palace System, in: J. Weilhartner and F. Ruppenstein (eds.), Tradition and Innovation in the Mycenaean Palatial Polities. Proceedings of an International Symposium held at the Austrian Academy of Sciences, Institute for Oriental and European Archaeology, Aegean and Anatolia Department, Vienna, 1-2 March, 2013, Vienna, 113-140.

Evely, R. D. G.

1988 The Potters' Wheel in Minoan Crete, The Annual of the British School at Athens 83, 83-126.

2000 Minoan crafts: tools and techniques: an introduction, Studies in Mediterranean Archaeology 92, Göteborg.

Evely, D. and Morrison, J. E.

2010 The Minoan Potter's Wheel: a Study in Experimental Archaeology, in: P. Matthiae, F. Pinnock, L. Nigro and N. Marchetti (eds.), Near Eastern Archaeology in the Past, Present and Future. Heritage and Identity. Ethnoarchaeology and Interdisciplinary Approach, Results and Perspectives. Visual Expression and Craft Production in the Definition of Social Relations and Status, Volume 1, Proceedings of the 6th International Congress of the Archaeology of the 
Ancient Near East, 5 May - 10 May 2009, “Sapienza”, Università di Roma, Wiesbaden, 283-288.

FimMEN, D.

1921 Die kretisch-mykenische Kultur, Leipzig, Berlin.

French, E. B., Hoffmann S. M. A., Robinson V. J. and TomlinSON J. E.

2008 Appendix 3. The Perlman and Asaro Analyses of Late Helladic I-III Sherds from the 1964 Excavations: A statistical re-evaluation, in: W. D. Taylour and R. Janko (eds.), Ayios Stephanos: Excavations at a Bronze Age and Medieval Settlement in Southern Laconia, Annual of the British School at Athens, Supplementary Volume 44, London, CD-118-123.

Furtwaengler, A. and Loeschcke, G.

1886 Vorhellenische Thongefässe aus dem Gebiete des Mittelmeeres, Berlin.

FURUMARK, A.

1941 The Mycenaean Pottery. Analysis and Classification, Stockholm.

GeLBERT, A.

1997 De l'élaboration au tour au tournage sur motte: difficultés motrices et conceptuelles, Techniques et Culture 30, 1-23.

Gilstrap, W.D., Day, P. and Kilikoglou, V.

2016 Pottery Production at two Neighbouring Centres in the Late Bronze Age Saronic Gulf: Historical Contingency and Craft Organisation, Journal of Archaeological Science Reports 369, 2-11.

Gorogianni, E., Pavúk, P. and Girella, L. (eds.)

2016A Beyond Thalassocracies: understanding processes of Minoanisation and Mycenaeanisation in the Aegean, Oxford.

Gorogianni, E., Abell, N. and Hilditch, J.

2016B Reconsidering Technological Transmission: The Introduction of the Potter's Wheel at Ayia Irini, Kea, Greece, AJA 120, 195-220.

Gosselain, O.P

2000 Materializing Identities: An African Perspective, Journal of Archaeological Method and Theory 7/3 (2000), 187-217.

2011 Fine if I do, fine if I don't. Dynamics of Technical Knowledge in Sub-Saharan Africa, in: B.W. Roberts and M. Vander Linden (eds.), Investigating archaeological cultures: Material culture, variability, and transmission, Berlin, 211-227.

Gosselain, O.P. and Livingstone Smith, A.

2005 The source. Clay selection and processing practices in Sub-Saharian Africa, in: D. Bosquet, A. Livingstone Smith and R. Martineau (eds.), Pottery manufacturing processes: Reconstruction and interpretation, Actes du XIVème Congrès de l'UISSP, B.A.R., International Series 1349, Oxford, 33-47.
Hachtmann V.

Forthcoming Late Helladic I to IIA Pottery from Ayios Vasileios at Xirokambi, Laconia.

Hale, Ch. M.

2016 The Middle Helladic Fine Gray Burnished Sequence at Mitrou, East Lokris, Hesperia 85, 243-295.

Hansen Streily, A.

2000 Bronzezeitliche Töpferwerkstätten in der Ägäis und in Westanatolien, PhD Dissertation, University of Mannheim, Mannheim https://madoc.bib.uni-mannheim. de/1133/ (last access 17.10.2019)

HASAKI, E.

2019 Potters and their Wheels in Ancient Greece: Skills and Secrets in Communities of Practice, in: M. Denti and M. Villette (eds.), Archéologie des espaces artisanaux. Fouiller et comprendre les gestes des potiers, Rennes, 297-314.

Haskell, H. W., Jones, R. E., Day, P. M. and Killen, J. T.

2011 Transport Stirrup Jars of the Bronze Age Aegean and East Mediterranean, Prehistory Monographs 33, Philadelpia/Pennsylvania.

Hruby, J. A.

2006 Feasting and Ceramics: A view from the Palace of Nestor at Pylos, PhD Dissertation, University of Cincinnati, Cincinnati, http://www.ohiolink.edu/etd/view. cgi?acc\%5Fnum=ucin 1155830535

2014 Moving from Ancient Typology to an Understanding of the Causes of Variability: a Mycenaean Case Study, in: A. Kotsonas (ed.), Understanding Standardization and Variation in Mediterranean Ceramics. Mid $2^{\text {nd }}$ to late $1^{\text {st }}$ Millennium BC, Leuven, Paris, Walpole, 49-58.

JEFFRA, C.

2011 An examination of emic possibilities: experimental archaeology and Cypriot ceramic typology, in: S. Scarcella (ed.), Archaeological Ceramics: A Review of Current Research, BAR-International Series 2193, Oxford, 103-116.

2013 A Re-examination of Early Wheel Potting in Crete, The Annual of the British School at Athens 108, 31-49.

Johnston, R.H. and Betancourt, P.P.

1984 Xeroradiography studies, in: P.P. Betancourt (ed.), East Cretan white-on-dark ware. Studies on a handmade pottery of the Early to Middle Minoan periods, Philadelphia, 114-117.

Jones, R. E. and Tomlinson, J. E.

2009 Appendix G. Chemical analysis of Mycenaean pottery from Menelaion and its vicinity, in: H. W. Catling, Sparta: Menelaion I. The Bronze Age, Annual of the British School at Athens Supplement 45, CD-147-169, Athens. 
Jones, R. and LeVI, S.T.

2014 Chapter 4. Characterisation and Provenance, in: R. Jones, S.T. Levi, M. Bettelli and L. VAgnetti, ItaloMycenaean Pottery: the Archaeological and Archaeometric Dimensions, Incunabula Graeca 103, Rome, 101-362.

Jung, R.

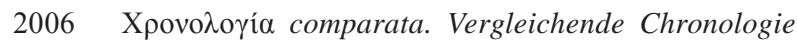
von Südgriechenland und Süditalien von ca. 1700/ 1600 bis 1000 v. u. Z., Veröffentlichungen der Mykenischen Kommission 26, Vienna.

2015 Imported Mycenaean Pottery in the East: Distribution, Context and Interpretation, in: B. EDER and R. Pruzsinszky (eds.), Policies of Exchange. Political Systems and Modes of Interaction in the Aegean and the Near East in the 2nd Millennium B.C.E. Proceedings of the International Symposium at the University of Freiburg, Institute for Archaeological Studies, 30th May - 2nd June 2012, OREA 2, Vienna, 243-275.

Forthcoming Mycenaean and other Painted Pottery from Tall Zirā'a, in: Dieter Vieweger - Jutta Häser (eds.) Tall Zirā‘a - The Gadara Region Project (2001-2011) Vol. 3 Late Bronze Age (Gütersloh), forthcoming.

Kardamaki, E.

2009 Ein neuer Keramikfund aus dem Bereich der Westtreppe von Tiryns. Bemalte mykenische Keramik aus dem auf der Westtreppenanlage deponierten Palastschutt, PhD Dissertation, Universität Heidelberg, Heidelberg. <http://archiv.ub.uni-heidelberg.de/ volltextserver/14756/> (last accessed March 16 $6^{\text {th }}$ 2019)

2015a A New Group of Figures and Rare Figurines from a Mycenaean Workshop Installation at Kontopigado, Alimos (Athens), Mitteilungen des Deutschen Archäologischen Instituts Athenische Abteilung 127128/2012-2013 (2015), 47-90.

2015b Conclusions from the new deposit at the Western Staircase terrace at Tiryns, in: Schallin and TourNAvitou 2015, 79-97.

2017 The Late Helladic IIB to IIIA2 Pottery Sequence from the Mycenaean Palace at Ayios Vasileios, Laconia, Archaeologia Austriaca 101 (2017), 73-142.

Forthcoming Ein neuer Keramikfund aus dem Bereich der Westtreppe von Tiryns. Bemalte und unbemalte mykenische Keramik aus dem auf der Westtreppenanlage deponierten Palastschutt, forthcoming.

Kardamaki, E., Day, P. M., Tenconi, M, Maran, J. and Papadimitriou, A.

2016 Transport Stirrup Jars in Late Mycenaean Tiryns: Maritime transport containers and commodity movement in political context, in: S. Demesticha and B. KnApp (eds.), Maritime transport containers in the Bronze-Iron Age Aegean and Eastern Mediterranean, Uppsala, 145-167.
Kaza-Papageorgiou, K., Kardamaki, E., Koutis, P., MarkoPOUlou, E. and Mouka, N.

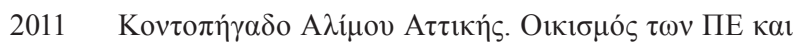

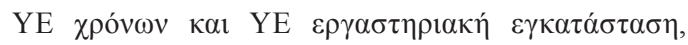
Archaiologike Ephemeris 150 (2011), 197-274.

Kaza-Papageorgiou, K., Kardamaki, E.

2018 A LH IIIA1 deposit from Kontopigado, Alimos and Processes of Mycenaeanization at Athens, Mitteilungen des Deutschen Archäologischen Instituts Athenische Abteilung 133 (2018), 1-58.

KNAPPETT, C.

1999 Tradition and innovation in pottery forming technology. Wheel-throwing at Middle Minoan Knossos, Annual of the British School at Athens 94 (1999), 101129.

2004 Technological Innovation and Social Diversity at Middle Minoan Knossos, in: C. Cadogan, E. Hatzaki and A. Vasilakis (eds.) Knossos: Palace, City, State. Proceedings of the Conference in Herakleion Organized by the British School at Athens and the $23^{\text {rd }}$ Ephoreia of Prehistoric and Classical Antiquities of Herakleion, in November 2000, for the Centenary of Sir Arthur Evan's Excavations at Knossos, British School at Athens Studies 12, London, 257-265.

2016 Resisting Innovation? Learning, Cultural Evolution and the Potter's Wheel in the Mediterranean Bronze Age, in: L. Mendoza Straffon (eds.), Cultural Phylogenetics: Concepts and Applications in Archaeology, Berlin, 97-111.

KNAPPETt, C. and HiLditch, J.

2015 Colonial Cups? The Minoan Plain Handleless Cup as Icon and Index, in: C. Glatz (ed.), Plain Pottery Traditions of the Eastern Mediterranean and Near East: Production, Use, and Social Significance, Publications of the Institute of Archaeology, University College London. Walnut Creek, California, 91-113.

Knappett, C. and VAN Der Leeuw, S.E.

2014 A developmental approach to ancient innovation. The potter's wheel in the Bronze Age East Mediterranean, Pragmatics and Cognition 22 (2014), 64-92.

Koulidou, S, Zangou, E., Batzikosta, E., Panteliadou, K. and Tsianaka, A.

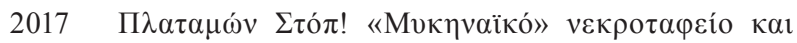

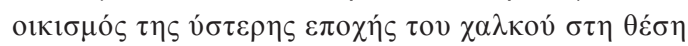

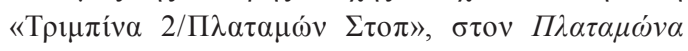

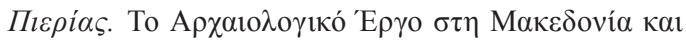

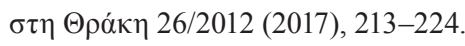

Kozatsas, J., Kotsakis, K., Sagris, D. and David, K.

2018 Inside out: Assessing pottery forming techniques with micro-CT scanning. An example from Middle Neolithic Thessaly. Journal of Archaeological Science 100 (2018), 102-119. 
Lang, J., Middleton, A., Ambers, J. and Higgins, T.

2005 Radiographic images, in: J. LANG AND A. Middleton (eds.), Radiography of cultural material, Amsterdam, 20-48.

Leonard, A., Hughes, M., Middleton, A. and Schofield, L.

1993 The Making of Aegean Stirrup Jars: Technique, Tradition, and Trade, Annual of the British School at Athens 88 (1993), 105-123.

Levi, S.T. and Cannavò, V.

2014 Manufacturing Process, in: R. Jones, S.T. Levi, M. Bettelli and L. VAgnetti, Italo-Mycenaean Pottery: the Archaeological and Archaeometric Dimensions, Incunabula Graeca 103, Rome, 364-376.

Lindblom, M. and Manning, S.

2011 The Chronology of the Lerna Shaft Graves, in: W. Gauss, M. Lindblom, R.A.K. Smith and J.C. Wright (eds.), Our Cups are Full: Pottery and Society in the Aegean Bronze Age. Papers Presented to Jeremy Rutter on the Occasion of his 65th Birthday, Oxford, 140-153.

Lindblom, M., Gauss, W. and Kiriatzi, E.

2015 Some Reflections on Ceramic Technology Transfer at Bronze Age Kastri on Kythera, Kolonna on Aegina, and Lerna in the Argolid, in: W. Gauss, G. KLeBindER-GAuss and C. VON RÜDEN (eds.), The Transmission of Technical Knowledge in the Production of Ancient Mediterranean Pottery. Proceedings of the International Conference at the Austrian Archaeological Institute at Athens, $23^{\text {rd }}-25^{\text {th }}$ November 2012, Österreichisches Archäologisches Institut Sonderschriften 54, Vienna, 225-237.

Lis, B.

2016 A Foreign Potter in the Pylian Kingdom? A Reanalysis of the Ceramic Assemblages of Room 60 in the Palace of Nestor at Pylos, Hesperia 85 (2016), 491536.

2017 Variability of ceramic production and consumption on the Greek mainland during the middle stages of the Late Bronze Age: the waterpots from the Menelaion, Sparta, Oxford Journal of Atchaeology 36.3., 2017, 243-266.

Livingstone Smith, A.

2007 Chaîne opératoire de la poterie: références ethnographiques, analyses et reconstitution, $\mathrm{PhD}$ Dissertation, Université Libre de Bruxelles, Bruxelles.

Livingstone Smith, A. and Viseyrias, A.

2010 Shaping Kabambian pottery: identification and definition of technical features, The Open Anthropology Journal 3 (2010), 124-141

Lólos, Y.B.

1987 The Late Helladic I Pottery of the Southwestern Peloponnesos and its Local Characteristics, Studies in Mediterranean Archaeology Pocket-Book 50, Göteborg.
MacGilivray, J.A.

1998 Knossos: Pottery Groups of the Old Palace Period, London.

Marabea, Ch.

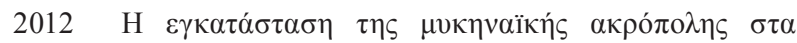

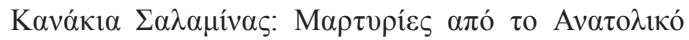

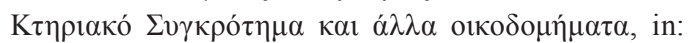
G. G. Lolos (ed.), $\Sigma \alpha \lambda \alpha \mu i \varsigma_{\varsigma}$ I. $\Sigma v \mu \beta o \lambda \dot{\eta} \sigma \tau \eta v$

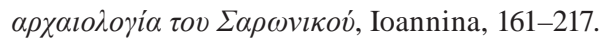

2019 Late Bronze Age Aeginetan Coarse Pottery at Kanakia, Salamis: A Macroscopic Study, Hesperia 88 (2019), 447-525.

MARAN, J.

1992 Kiapha Thiti. Ergebnisse der Ausgrabungen II 2 (2 Jt. v. Chr. Keramik und Kleinfunde), MarbWPr 1990, Marburg.

Marketou T., Karantzali, E. Mommsen, H., Zacharias, N., Kilikoglou, V. and Schwedt, A.

2006 Pottery Wares from the Prehistoric Settlement at Ialysos (Trianda) in Rhodes, Annual of the British School at Athens 101 (2006), 1-55.

Marthari, M.

1993 The Ceramic Evidence for Contacts Between Thera and the Greek Mainland, in: C. Zerner, P. Zerner and J. Winder (eds.), Wace and Blegen. Pottery as Evidence for Trade in the Aegean Bronze Age 1939-1989. Proceedings of the International Conference Held at the American School of Classical Studies at Athens, Athens, December 2-3, 1989, Amsterdam, 249-256.

Middleton, A.

2005 Ceramics, in: J. Lang and A. Middleton (eds.), Radiography of cultural material, Amsterdam, 76-95.

Minar, C.J. and Crown, P.L.

2001 Learning and craft production: an introduction, Journal of Anthropological Research 57 (2001), 369-380.

Mommsen, H., Lewandowski, E., Weber, J. and Podzuweit, Ch.

1988 Neutron activation analysis of Mycenaean pottery from the Argolid: The search for reference groups, in: Proceedings of the $26^{\text {th }}$ International Archaeometry Symposium, Held at University of Toronto, Toronto, Canada, May $16^{\text {th }}$ to May $20^{\text {th }}$, 1988, Toronto, 165171.

Mommsen, H., Beier, Th. and Hein, A.

2002 A complete chemical grouping of the Berkeley neutron activation analysis data on Mycenaean pottery, Journal of Archaeological Science 29 (2002), 613637.

MORRIS, S.P.

2009-2010 Prehistoric Torone: A Bronze Age Emporion in the Northern Aegean. Preliminary Report on the Lekythos Excavations 1986 and 1988-1990, Mediterranean Archaeology 22-23 (2010), 1-67. 
Morrison, J.E. and PARK, D.P.

2007 Throwing small vessels in the LM IB Mochlos potter's pit. Kentro: Newsletter of the INSTAP Study Center for East Crete 10 (2007), 6-10.

MountJoy, P.A.

1981 Four Early Mycenaean Wells from the South Slope of the Acropolis at Athens, Miscellanea Graeca 4, Gent.

1986 Mycenaean Decorated Pottery: A Guide to Identification, Studies in Mediterranean Archaeology 73, Göteborg.

1993 Mycenaean Pottery. An Introduction, Oxford University Committee for Archaeology Monograph 36, Oxford.

1999 Regional Mycenaean Decorated Pottery, Rahden/ Westfalen.

2007 The Mycenaean and Late Minoan I-II Pottery, in: C. Renfrew, N. Brodie, Ch. Morris and $\mathrm{Ch}$. Scarre (eds.), Excavations at Phylakopi in Melos 1974-77, London, 307-370.

2015 The North-east Peloponnese and the Near East: Ceramic Evidence for Contacts in LH III, in: SchaLLIN and TOURnAVITOU 2015, 533-554.

Mountjoy, P.A. and Mommsen, $\mathrm{H}$.

2015 Neutron activation analysis of Aegean-style IIIC pottery from 11 Cypriot and various Near Eastern sites, Ägypten und Levante 25 (2015), 421-508.

Pierret, A.

1995 Analyse technologique des céramiques archéologiques: développements méthodologiques pour l'identification des techniques de façonnage. Un exemple d'application: le matériel du village des Arènes à Levroux (Inde), PhD Dissertation, Paris 1 Panthéon-Sorbonne, Paris.

Pierret, A., Moran, C.J. and Bresson, L.M.

1996 Calibration and visualization of wall-thickness and porosity distributions of ceramics using X-radiography and image processing, Journal of Archaeological Science 23 (1996), 419-428.

Pigeot, N.

2011 Chaînes opératoires: contexte théorique et potentiel cognitive, in: R. Treull (ed.), L'archéologie cognitive, Paris, 149-171.

Podzuweit, $\mathrm{CH}$.

2007 Studien zur spätmykenischen Keramik, Tiryns 14, Wiesbaden.

Powell, C.

1995 The nature and use of ancient Egyptian potter's wheels, in: B.J. KemP (ed.), Amarna Reports VI, London, 309-335.

Rice, P.M.

1987 Pottery Analysis. A sourcebook, Chicago/London.
Roux, V.

1994 La technique du tournage: définition et reconnaissance par les macrotraces, in: F. Audouze and D. BINDER (eds.), Terre cuite et société: la céramique, document technique, économique, culturel. XIVe Rencontres Internationales d'Archéologie et d'histoire d'Antibes, Juan-les-Pins, 45-58.

2003 A dynamic systems framework for studying technological change: application to the emergence of the potter's wheel in the Southern Levant, Journal of Archaeological Method and Theory 10/1 (2003), 1-30.

2007 Ethnoarchaeology: a non historical science of reference necessary for interpreting the past, Journal of Archaeological Method and Theory 14/2 (2007), 153178.

2008 Evolutionary trajectories of technological traits and cultural transmission: a qualitative approach to the emergence and disappearance of the ceramic wheelfashioning technique in the southern Levant during the fifth to third millennia BC, in: M. Stark, B. BowER and L. Horne (eds.), Cultural transmission and material culture. Breaking down the boundaries, Tucson, 82-104.

2009 Wheel fashioned ceramic production during the third millennium BCE in the Southern Levant: a perspective from Tel Yarmuth, in: S. Rosen and V. Roux (eds.), Techniques and people: anthropological perspectives on technology in the archaeology of the proto-historic and early historic periods in the Southern Levant, Paris, 195-212.

2010 Technological innovations and developmental trajectories: social factors as evolutionary forces, in: M.J. O’Brien and S.J. Shennan (eds.), Innovation in Cultural Systems. Contributions from Evolutionary Anthropology, Cambridge, Massachusetts, London, 217-234.

2011a Habiletés et inventions: Le comportement «intelligent», un facteur aléatoire dans l'évolution des techniques», in: R. Treull (ed.), L'archéologie cognitive, Paris,173-188.

2011b Anthropological interpretation of ceramic assemblages: foundations and implementations of technological analysis, in: S. Scarcella, Archaeological Ceramics: A Review of Current Research, Oxford, 80-88.

2017 Des céramiques et des hommes. Décoder les assemblages archéologiques, Paris.

Roux, V. and BriLL, B.

2002 Des programmes d'apprentissage comparables pour des actions techniques différentes, in: B. BRIL and V. Roux (eds.), Le geste technique. Réflexions méthodologiques et anthropologiques, Revue d'Anthropologie des connaissances, Technologies/ Idéologies/ Pratiques vol. 14.2, Ramonville Saint-Agne, 231-242. 
Roux, V. and CORBETtA, D.

1990 Le tour du potier: spécialisation artisanale et compétences techniques, Paris.

Roux, V. and Courty, M.A

1998 Identification of wheel-fashioning: technological analysis of 4th-3rd millennium B.C. Oriental ceramics, Journal of Archaeological Science 25 (1998), 747763.

2005 Identifying social entities at a macro-regional level: Chalcolithic ceramics of South Levant as a case study, in: D. Bosquet, A. Livingstone Smith and R. MarTINEAU (eds.), Pottery manufacturing processes: reconstruction and interpretation, Actes du XIVème Congrès de l'UISSP, B.A.R., International Series 1349, Oxford, 67-78.

Roux, V. and Miroschedji, P. de

2009 Revisiting the History of the Potter's Wheel in the Southern Levant, Levant 41/2 (2009), 155-174.

RÜCKL, V. and JACOBS, L.

2016 With a little help from my wheel: wheel-coiled pottery in Protogeometric Greece, Hesperia, Hesperia 85 (2016), 297-321.

RUTTER, J.B.

1993 A Group of Late Helladic IIA Pottery from Tzoungiza, Hesperia 62 (1993), 53-93.

2015 Ceramic Technology in Rapid Transition. The Evidence from Settlement Deposits of the Shaft Grave Era at Tsoungiza (Corinthia), in: W. Gauss, G. KLebinder-Gauss and C. von Rüden (eds.), The Transmission of Technical Knowledge in the Production of Ancient Mediterranean Pottery. Proceedings of the International Conference at the Austrian Archaeological Institute at Athens, $23^{\text {rd }}-25^{\text {th }}$ November 2012, Österreichisches Archäologisches Institut Sonderschriften 54, Vienna, 207-223.

RYE, O. S.

1977 Pottery manufacturing techniques: X-ray studies, Archaeometry 19/2 (1977), 205-211.

1981 Pottery Technology: Principles and Reconstruction, Taraxacum.

Schallin, A.-L. and Tournavitou, I. (eds.)

2015 Mycenaeans Up to Date. The Archaeology of the North-Eastern Peloponnese - Current Concepts and New Directions, Stockholm.

SCHLANGER, N.

2005 The chaine opératoire, dans C. RENFrew and P. BAHN (eds.), Archaeology: the key concepts, London/New York, 18-23.

SCHÖNFELD, G.

1988 Ausgrabungen in Tiryns 1982/83. Bericht zur bemalten mykenischen Keramik. Die Phasen SH IIIA-Spät bis SH IIIB-Mitte, Archäologischer Anzeiger 1988, 153-211.
SheLton, K.

2015 Pottery and Petsas House. Recent Research on LH IIIA2 Mycenae, in: Schallin and Tournavitou 2015, 27-36.

SPENCER, L.

2007 Pottery Technology and Socio-Economic Diversity on the Early Helladic III to Middle Helladic II Greek Mainland, PhD Dissertation, London.

2010 The Regional Specialisation of Ceramic Production in the EH III through MH II Period, in: A. Philippa-TouChais, G. Touchais, S. Voutsaki and J. Wright (eds.), Mesohelladika : La Grèce continentale au Bronze Moyen, actes du Colloque international, organisé par l' École française d'Athènes, en collaboration avec l'American School of Classical Studies at Athens et le Netherlands Institute in Athens, Athènes, 8-12 mars 2006, Bulletin de correspondance hellénique Suppl. 52, Athens, 669-681.

THÉR, R.

2016 Identification of pottery-forming techniques using quantitative analysis of the orientation of inclusions and voids in thin sections, Archaeometry 58 (2016), 222-238.

Thomas, P. M.

2005 A Deposit of LH III B1 Pottery from Tsoungiza, Hesperia 74 (2005), 451-573.

2011a A Deposit of LH IIIA2 Pottery from Tzoungiza, Hesperia 80/2 (2011), 171-228.

2011b Mycenaean tablewares and the curious careers of the angular Kylix and shallow angular basin, in: W. Gauss, M. Lindblom, R. Angus K. Smith and J. C. Wright (eds.), Our Cups Are Full: Pottery and Society in the Aegean Bronze Age. Papers presented to Jeremy B. Rutter on the Occasion of his 65th Birthday, Oxford, 297-305.

TODARO, S.

2019 Shaping tools and finished products from a longterm pottery production are at Phaistos. A combined approach to the study of hand-forming techniques in Early and Middle Minoan Crete, Creta Antica 17 (2016), 273-325.

Tomlinson, J. E., Rutter, J. B. and Hoffmann, S. M. A.

2010 Mycenaean and Cypriot Late Bronze Age Ceramic Imports to Kommos. An Investigation by Neutron Activation Analysis, Hesperia 79 (2010), 191-213.

VANDIVER, P.B.

1987 Sequential slab construction: a conservative southwest Asiatic ceramic tradition, ca. 7000-3000 B.C., Paléorient 13/2 (1987), 9-35.

Vasilogamvrou, A.

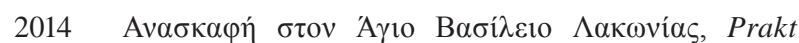
166/2011 (2014), 59-68. 


\section{Vitale, S.}

2018 The troubled century? Potting practices and sociopolitical changes at Mitrou, East Lokris, between the end of the 14th and the beginning of the 12 th c. BC, in: I. CAloo and Ch. Langohr (eds.), Technology in Crisis. Technological changes in ceramic production during periods of trouble, Louvain-la-Neuve, 151176.

Wardle, K. A.

1969 A Group of Late Helladic III B1 Pottery from within the Citadel at Mycenae, Annual of the British School at Athens 64 (1969), 261-297.
Xanthoudides, S.

1927 Some Minoan potter's-wheel discs, in: S. CASSON (ed.), Essays in Aegean archaeology presented to Sir Arthur Evans in honour of his 75th birthday, Oxford, 111-128.

ZERNER, C.

2008 The Middle Helladic Pottery, with the Middle Helladic Wares from Late Helladic deposits and the potters' Marks, in: W. D. TAYlour and R. JANKo (eds.), Ayios Stephanos: Excavations at a Bronze Age and Medieval Settlement in Southern Laconia, Annual of the British School at Athens Supplementary Vol. 44, London, 177-298. 